جودة الحياة و الميول المهنية لاى أطفال المؤسسات الإيوائية و أقرانهم الذين يعيشون مع أسرهم

دكتور / حمدى محمد شحاته عرقوب

مدرس بمعهد الاراسات التريويه - جامعه القاهزة

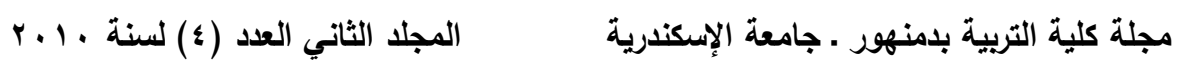


جودة الحياة لاى أطفال المؤسسات الإيوائية وميونهم المهنية (دراسة مقارنة مع الأطفال الذين يعيشون مع أسرهم) د.حمدى محمد شحاته عرقوب 
جودة الحياة و الميول المهنية لدى أطفال المؤسسات الإيوائية و أقرانهم الذين

$$
\text { يعيشون مع أسرهم }
$$

دكتور / حمدى محمد شحاته عرقوب مئم لئم

$$
\text { مقدمة: }
$$

أكدت نتائج الدراسات' الحديثة على ضرورة دراسة جودة الحياة كمتغير إيجابى فى الثخصية بدلا من الاهتمام بدراسة الثخصية المرضية التى ظلت سائدة فى الفكر السيكولوجى لفترة زمنية طويلة فالإنسان لكى يعيش فى عالم

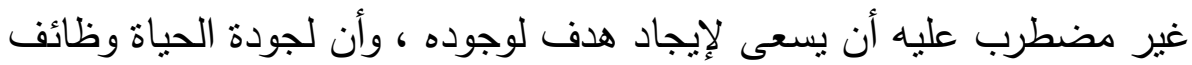

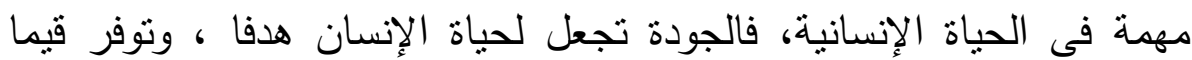

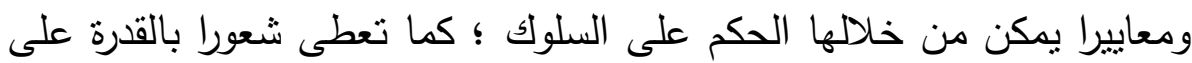
التحكم فى الحياة ،إضافة إلى ما تمنحه للإنسان من الثعتور بالقيمة الذاتية، وعليه فإن جودة الحياة ينظر إليها باعنبارها مفهوما إيجابيا ينبغى أن يمتلكه

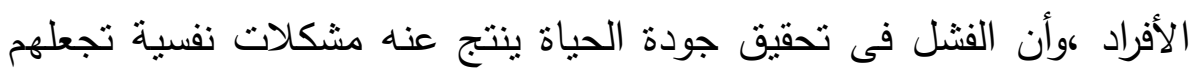

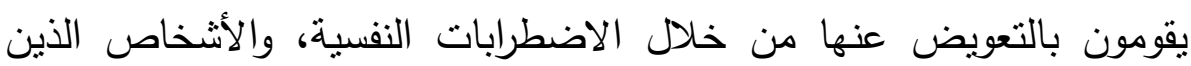
يمكنهم الوصول إلى مستوى مرتفع من جودة الحياة يشعرون بدرجة منخفضة هنسة

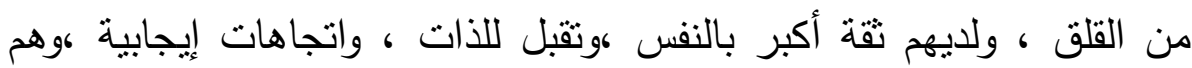

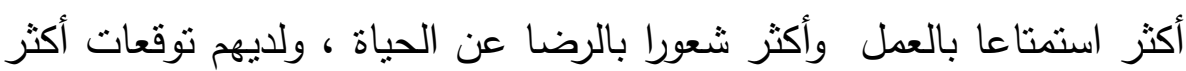

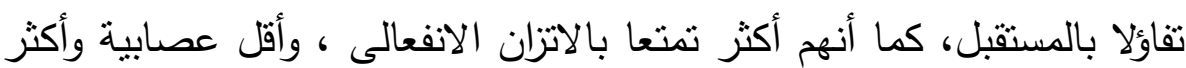
اجتماعية ،ولديهم القدرة على التحكم الذاتي والسعادة والصحة النفسية.

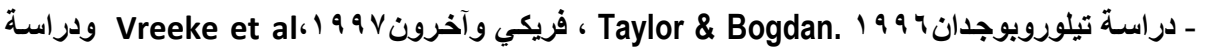

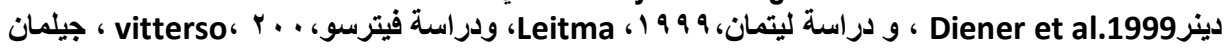

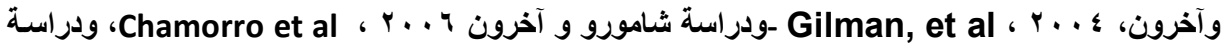

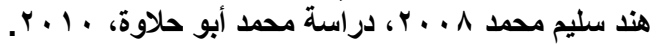


فجودة الحياة ليست فقط انعكاسا لما يقدمه المجتمع لأفراده من مظاهر

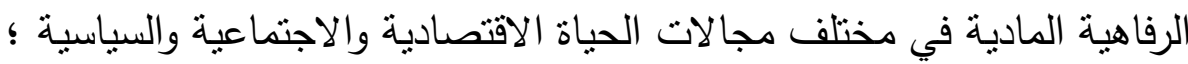
كالدخل و الخدمات ، والصحة والسكن والتعليم كجانب موضوعي فقط ؛ بل هي بالإضافة إلى ذللك تشمل جانبا ذاتيا يتمنل في مدى إدراك الفرد لهذه المظاهر الموضوعية ، ورضاه عن حياته ، وتقييمه الخاص لمصادر بيئته الموضوعية والفرص المتاحة أمامه لتحقيق ذاته وتتمية قدراته ، ومعايشته

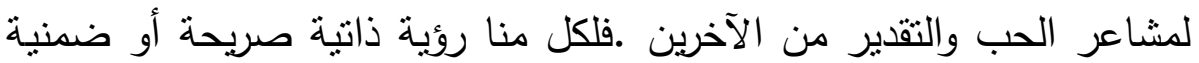
فيما يتعلق بالطريقة التي ينظم بها حياته الثخصية؛ رؤية ذاتية فيما يخص التصن نوعية حياته الثخصية وجودتها، فإذا لم يتمكن الفرد من تحقيق هذه الروئية

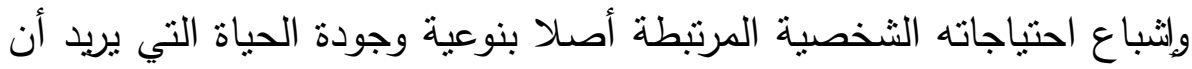
بعيشها، فعليه أن يستعين بالآخرين لتحقيق هذه الرؤية، وعليه فيجب أنبه النيه بركز المنوط بهم رعاية وتربية الأطفال بصفة خاصة كالآباء والمعلمين والاختصاصيين الاجتماعيين والنفسانيين على مساعدة الأفراد المسئولين منهم على تحقيق رؤيته الثخصية لنوعية وجودة حياتهر الثخصية، وأطفال

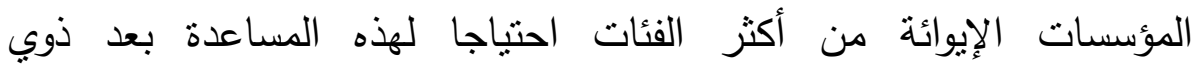
الاحتياجات الخاصة، نظرا لظروف معيشتهح وخصائصهم النفسية. إن جودة الحياة تتمثل في الثعور بالرضا والإحساس بالرفاهية والمتعة في ظل الظروف التي يحياها الفرد، وإدراكه أنه يعيش حياة جيدة من وجهة نظره، خالية من الأفكار اللاعقلانية، والانفعالات السلبية، والاضطرابات السلوكية،ويستمتع بوجوده الإنساني ويشعر بالرضا والسعادة، ويستثر كافة قدراته وامكانياته بما يتيح له تحقيق ذاته. وتلعب الأسرة دورا فاعلا في تشكيل الأفراد ونمو إمكاناتهم وتكوين نقافاتهر لتهاته

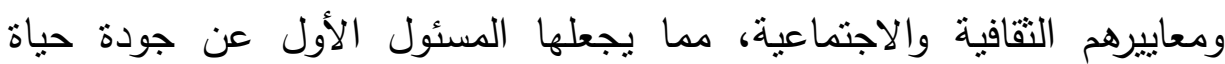
أبنائها، فهي تعتبر المؤسسة التربوية الأولى الموكل إليها إعداد وتتشئة الأطفال 
تتشئة سوية، تؤهلهم إلى أن يصبحوا أثخاصا أسوياء في المجتمع، وذلك من خلال إثباع حاجاتهم، ومساعدتهم على اكتساب المعايير الاجتماعية والقيم الأخلاقية السائدة في المجتمع، وتتمية اتجاهاتهم وميولهم واستعداداتهم وقدراتهم

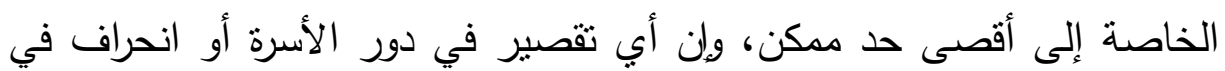

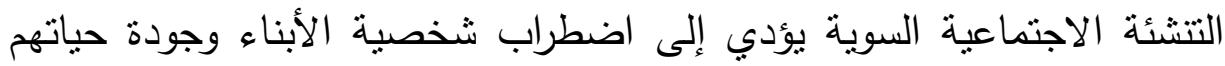

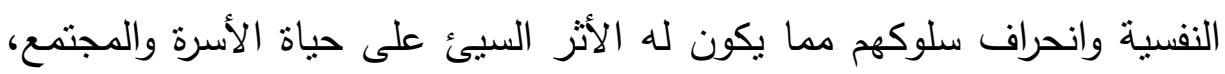

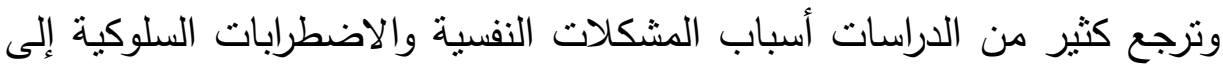
عدم إثباع حاجات الطفل واللى التنشئة الوالدية الخاطئة، أو الحرمان العاطفي لتحني نتيجة غياب أحد الوالدين أو كليهما وخاصة الأم. فقد ركزت معظم البحوث في البه نمو الطفل على العلاقة بين الأم والطفل، ومن النتيجة النهائية المعقولة بأن الأم

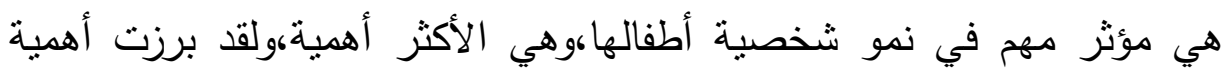
تأثيرات الأمومة وتضاعفت من خلال الاعتقاد السائد في دلالة وجوهرية خبرات الطفولة المبكرة، ولأن الأم هي المتضمنة في تلاك الخبرات. وتمثل العلاقة بين الطفل والأم علاقة تنادل، فالأم تقدم الحب والمساندة المادية، بينما الطفل يستجيب بالعاطفة والطاعة ، وكل من الأم والطفل يكسب الرضا من هذه العلاقة.

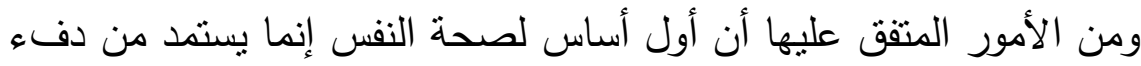
العلاقة بين الأم والطفل أو من يقوم مقامها بصفة دائمة وهي ما يطلق عليها

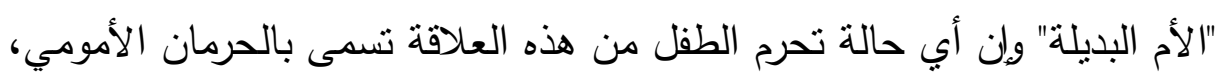

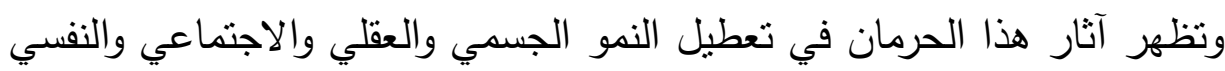
للطفل.

ولذا فإن الأطفال الذين ينشأون في ظروف خاصة تحرمهم من الرعاية الأسرية السوية غالبا ما يكونون عرضة للنقص في العلاقات الاجتماعية والرعاية الطبيعة، مما يؤدي إلى شعورهم بالنقص والدونية، ويتسم سلوكهم بالخوف والقلق والعدوانية والانسحاب الاجتماعي، ويؤثر ذلك على تقديرهم لذاتهم، ومستوى 
طموحهموجودة حياتهم، وبالتالي على مستوي نموهم المهني، حيث يميلون إلى

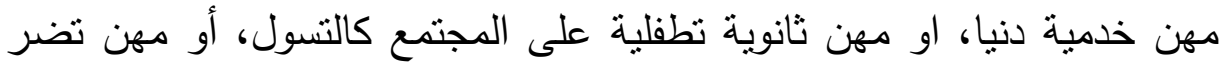

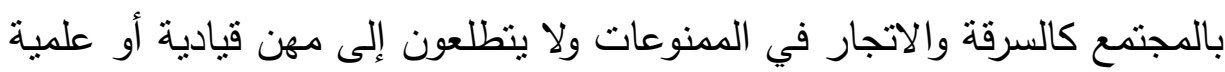

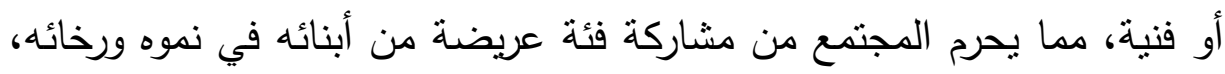

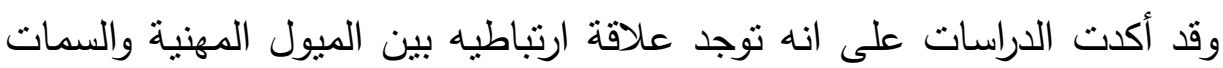
الثخصية كالاستقرار العاطفي والتفاؤل . وإذا كانت المؤسسات الإيوائية تلعب دورا رئيسا في تنشئة هؤلاء الأطفال

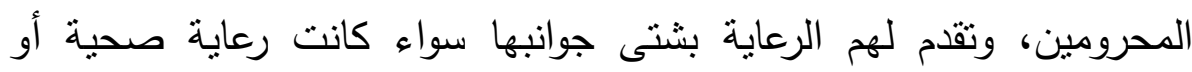
اجتماعية أو نفسية أو ثقافية أو مهنية بهدف إعدادهم لمستقبل أفضل، فإنها لا لانهاء

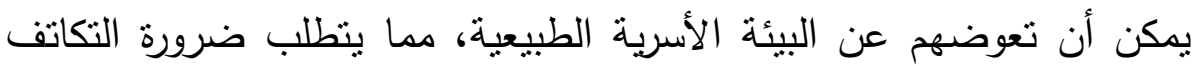

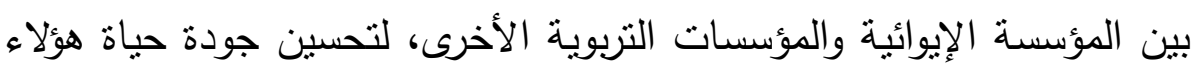
الأطفال، وتحسين اتجاهاتهم وميولهم المختلفة ومنها ميولهم المهنية. إن السياق الاجتماعي النقافي الذي يعيش فيه الطفل الدحروم قد يحول

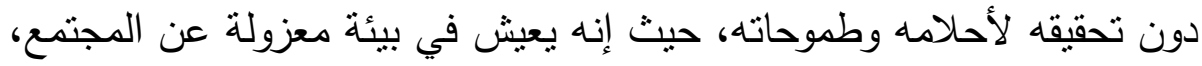

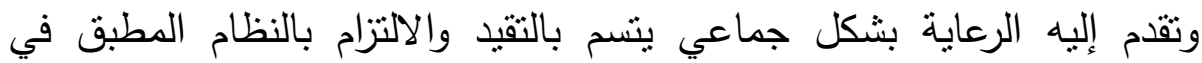

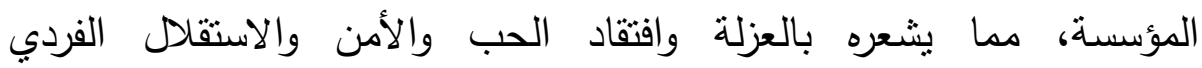
والخصوصية ، مما بيؤثز بشكل كبير على سعادته وجودة حياته، فالرعاية

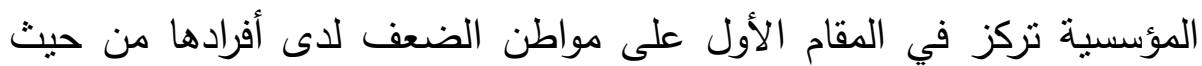

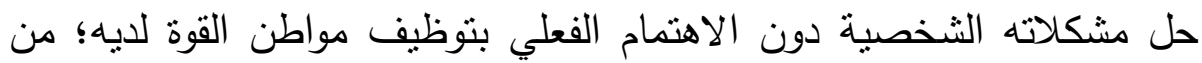

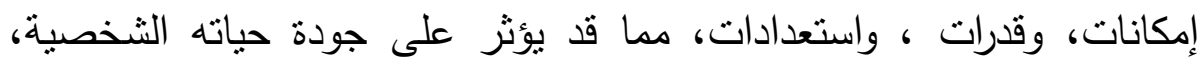
وينعكس ذللك على تقديره لذاته ودافعيته للإنجاز ، وميوله المهنية، إن مساعدة الأخصائي الاجتماعي لطفل المؤسسة في حل مشكلاته، تقود إلى تقييم ذلك الطفل الإيجابي للرعاية المقدمة له، وهذا يبين أهمية الدور الذي يلعبه

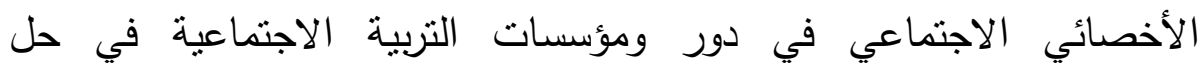


المشكلات التي تعترض أطفالها، ومساعدتهم، وتسهيل النقلة من العيش في أسر إلى العيش في مؤسسات، وذلك يستوجب إمداد دور ومؤسسات التربية الاجتماعية بأخصائيين اجتماعيين من المتخصصين في مجين ودال الخدمة الاجتماعية، وتأهيلهم بدورات تدريبية، وذلك حتى تتم مساعدة الأطفال وفق هن

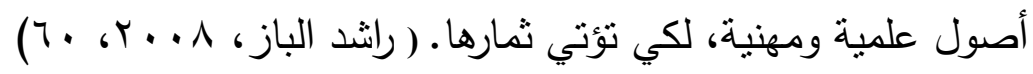
إن الاختيار المهني قديما كان قائما على العشوائية، إذ كان الثناب يلتحق لهقان بأي عمل بالصدفة المحضة، وكانت المواءمة المهنية بين الفرد بقدراته

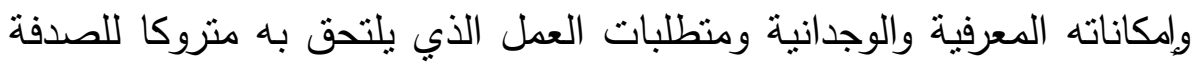
لا للاختيار ، كما كان اختيار العمل محكوما بالتوزيع الجغرافي للصناعات، أو لوانه

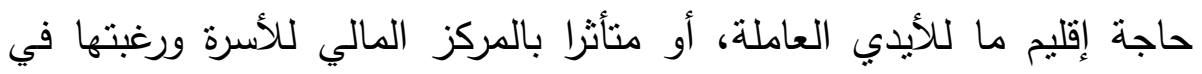

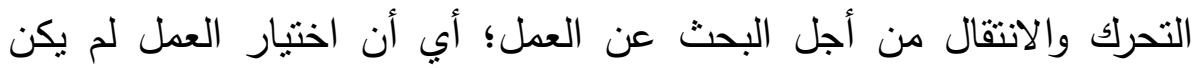

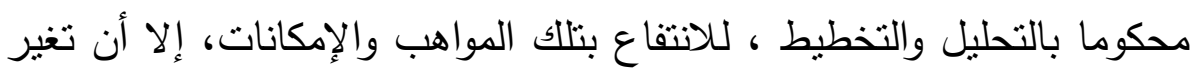
الأيدلوجية السياسية نحو تحقيق المساواة من أجل رفع العبء عن كاهل المحرومين وتحقيق الطمأنينة في العمل، وكذلك النمو الاقتصادي الذي يحتاج

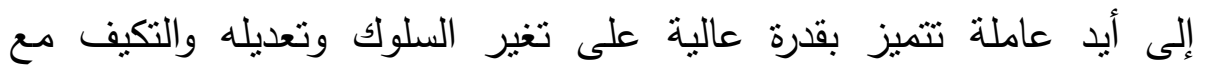
المواقف الجديدة في العمل، أدى إلى تغير هذه النظرة القديمة، واستخدام التوجيه المهني والإرشاد في المدارس ومحاولة الاستفادة بما لدى الفرد من مواهب وقدرات وتتميتها، مما يساعد الأفراد في مستقبل حياتهم على اختيار العمل الذي يحقق لهم السعادة والرضا ويسدي للمجتمع النفع والرخاء، وأطفال

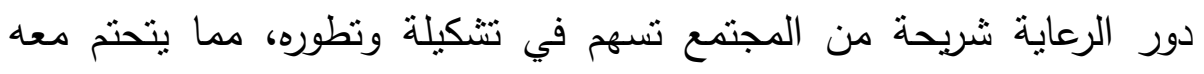

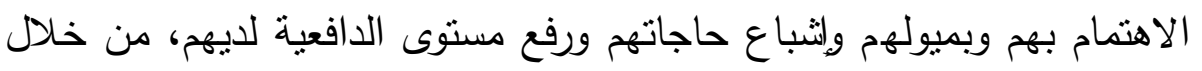

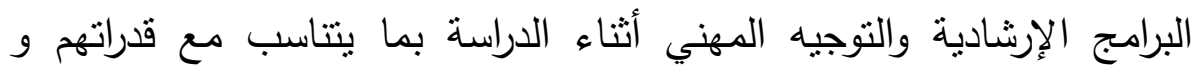
إمكاناتهم، ليستطيعوا تحقيق الاختيار المهني المناسب لهم في مستقبل حياتهم. 
ومن هذا المنطلق كانت هذه الدراسة التي تحاول بحث العلاقة بين جودة الحياة لأطفال دور الرعاية، ومعرفة أثز ذلك على ميولهم المهنية، مقارنة بأقرانهم الذين يعيشون مع أسرهم.. مشكلة الدراسة:

إن جودة الحياة تمثل مفهوماً واسعاً بتأثز بجوانب متداخلة من النواحي الذاتية والموضوعية، مرتبطة بالحالة الصحية والحالة النفسية للفرد، هُهداه

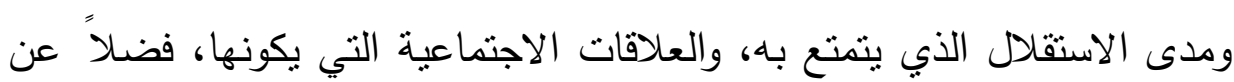

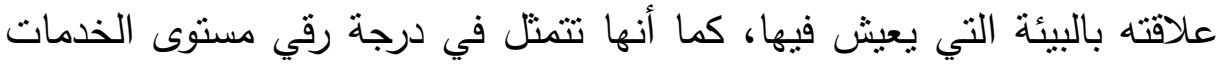

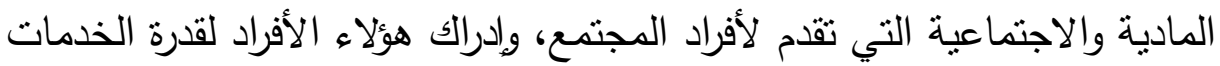

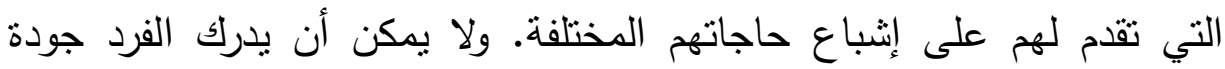
الخدمات التي تقدم له بمعزل عن الأفراد الذين يتفاعل معهم (أصدقاء وزملاء وأثقاء وأقارب)؛ أي أن جودة الحباة ترتبط بالبيئة المادية والبيئة النفسية

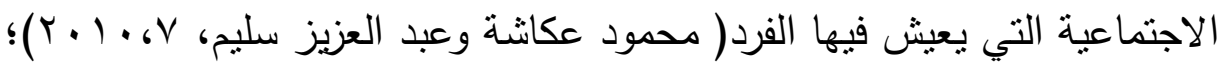
ولذلك فالبحث فيها يدفعنا إلى الاهتمام بالبيئات التعليمية وبيئات الرعاية الاجتماعية والصحية، وبالتالي يتيح التعاون بين الخبراء المهنيين المتخصصين في مجالات مختلفة، ويعطي دورا إيجابيا لكل من يهتم بتربية الطفل ابتداء من

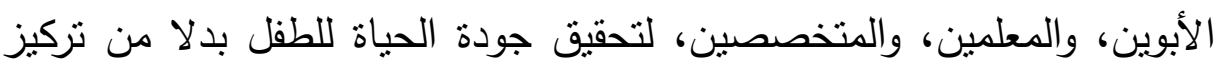
الاهنمام على الجانب المرضي والسلوك المشكل فقط.

وقد أنشارت العديد من الدراسات في مجال جودة الحياة، أن هناك ارتباطـا بين جودة الحياة وبعض المتغيرات الثخصية والاجتماعية، مثل القلق والذكاء الوجداني والانتباه والانفتاح ،والرضا عن الحياة والثبات الانفعالى والانبساطو و

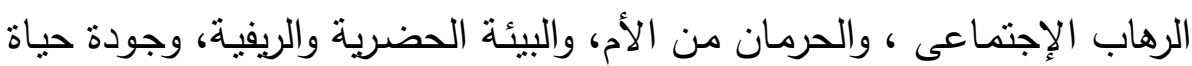

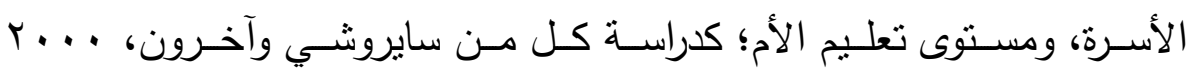


TCiarrochi , et al.

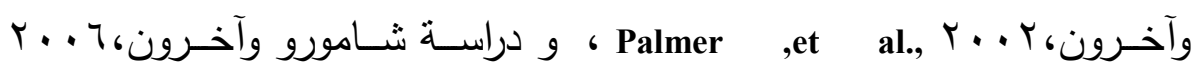
Chamorro et al6 ، دراسـة صفاء أحمد أحمد عجاجـة، V . . r، ودراسـة السبد

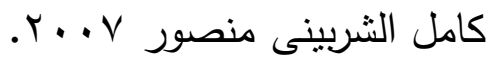
ولما كان الأطفال المحرومين من الفئات الأكثر تعرضا وراصابة بالاضطرابات السلوكية والمشكلات النفسية كما تؤكد ذلك كثير من الدراسات كدراسة ربيع يونس، و99 (، ودراسةآمال عبد السميع باظة، ؛99 19، ودراسة Stafford\& ، 1990، 1990، 1990، دراسة ستافورد واستافورد K.Stafford

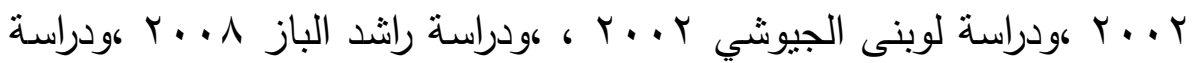

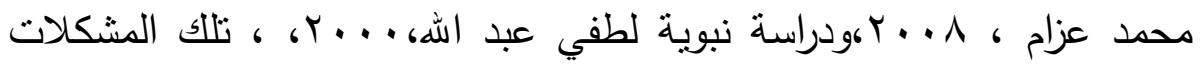
التي تصاحبهم حتى بعد تخرجهم من المؤسسة الإيوائية، فيجدوا صعوبة في الاندماج في المجتمع والمشاركة في أنشطنة الاجتماعية والاقتصادية المختلفة، وقد تتخفض درجة إدراكهم لجودة حياتهم ، وبزبد من مشكلاتهم النفسية والاجتماعية، مما بتطلب زيادة الاهتمام بهذه الفئة وتقديم البرامج الإرشادية والتدربيية في شتى المجالات وخاصة المجال المهني، بحيث تتحسن جودة حياتهم النفسية ليصبحوا أكثر توافقا ذاتيا واجتماعيا، وبنعكس ذلك على ميولهم المهنية ويستطيعون اختيار مهنة المستقبل التي تساعدهم على التعايش والاندماج في المجتمع والمساهمة في الإنتاج.

إن الدور الأساسي الذي يجب أن يضطلع به النظام التعليمي من حيث توجيه التلميذ إلى المهنة التي يفضلها، وتتميته لأدائها مازال غائبا في سياستتا التربوية، كما أن النظام التعليمي يغفل الاهتمام بتأثير الأسرة ، والمدرسة والمجتمع نفسيا واجتماعيا في تشكيل أسلوب الحياة المهنية للتلاميذ، وبترك هذا الجانب ذا الأهمية في تكوين شخصية الفرد للصدفة والعشوائية. 
وتؤكد نظرية التحليل النفسي على دور الدوافع اللاشعورية التي تكونت في

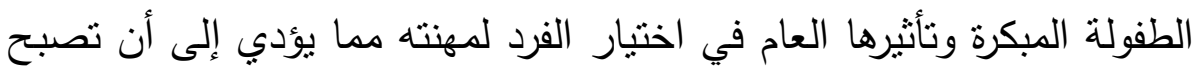

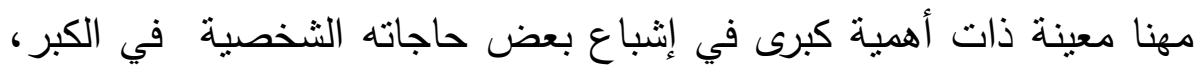

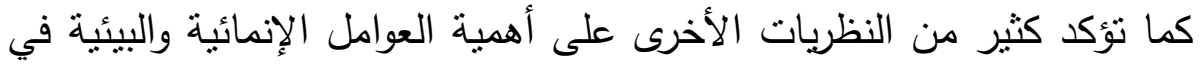

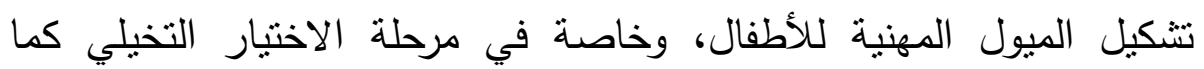

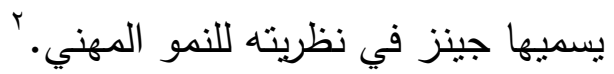

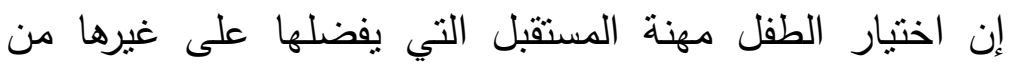

المهن نتاجا لتجربة اجتماعية خاصة تتفاعل فيها العوامل الاجتماعية والاقتصادية والمدرسية والبيئية المنتوعة، وهي في الوقت ذاته عامل أساسي من النهايه العوامل المؤثرة في شخصية الطفل، وموجه رئيس من موجهات السلوك.

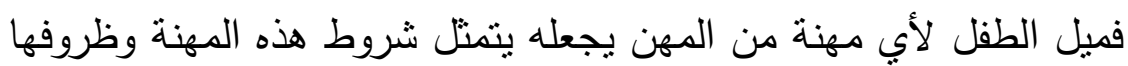
ويقيم أنماط سلوكه في ضوء تفضيله هذه المهنة أو تللك، فيستعيد من أنماط السلوك ما يجده بعيدا عن شروط هذه المهنة، ويقترب من الأنماط الثديدة الصلة بها، ورغم أن هذا التمبيز يقتضي وضوح المهنة في تصوره، ويرتبط بدرجة الرغبة بممارسة هذه المهنة أو تلك؛ إلا أن الميل في حد ذاته ينطوي على ثقافة يقوم عليها، وهو ليس سلوكا اعتباطيا لا يمكن تفسيره، بل هو سلوك

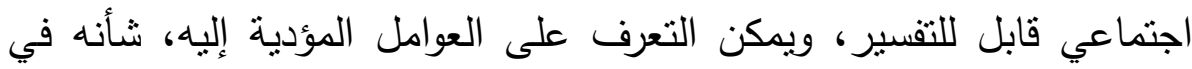

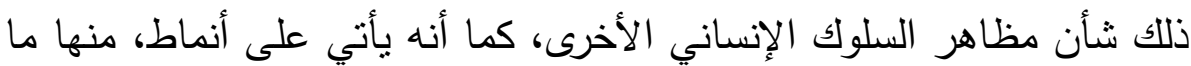
يوافق الثروط المحيطة، ويينى على أسس مستمدة من خصائص شخصية الطفل نفسه، ومنها ما يبني على غير توافق وبتأثير البيئة المحيطة، وغالبا ما يترتب على ذلك جملة من الآثار السلبية التي تمس حياة الفرد، وتؤثر في 
شخصيته، وفي أدائه الاجتماعي وتفاعله مع الآخرين.( أمل دكاك وأحمد

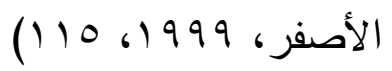

وقد شارك الباحث في دراسة مسحية لمؤسسة أمان التابعة للجمعية العامة

للافاع الاجتماعي عام ب...ب و التي هدفت إلى التعرف على الميول المهنية

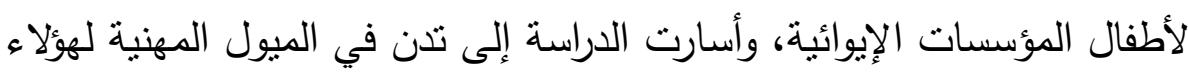

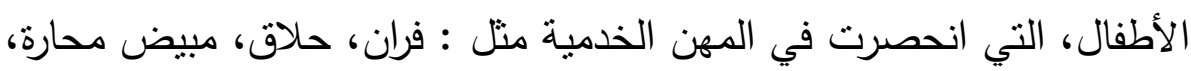

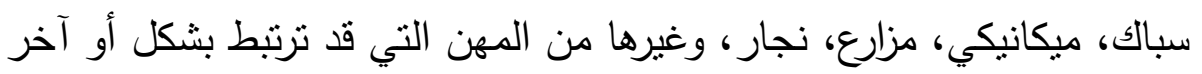

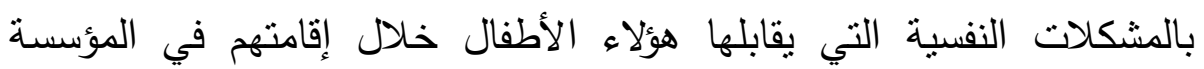
الإيوائية، أو بالسمات الثخصية لهم، مثل المخاوف والاضطرابات السلوكية، والتبول اللاإرادي، وانخفاض مفهوم الذات ، وضعف الدافعية للإنجاز . مما دفع الباحث إلى محاولة التعرف على العلاقة بين جودة حياة أطفال

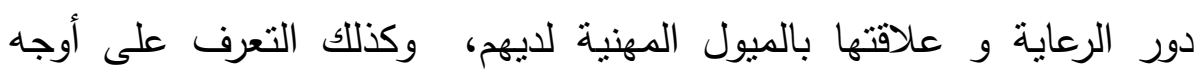

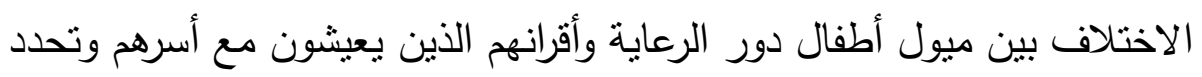
مشكلة الدراسة في التساؤلات الآتية:

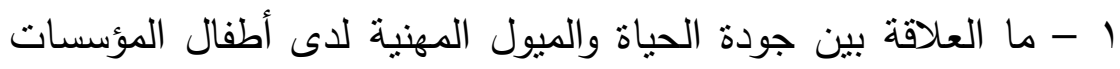
الإيوائية وأقرانهم الذين يعيشون مع أسرهم. r - هل تختلف جودة الحياة والميول المهنية لدى كل من لهن أطفال المؤسسات الإيوائية وأقرانهم الذين يعيشون مع أسرهم. r - ما أكثر الميول المهنية شيوعا لدى أطفال المؤسسات الإيوائية وأقرانهم

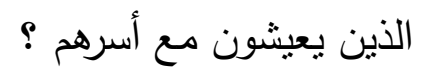
الهدف من الدراسة: تهدف الدراسة الحالية إلى: I - التعرف على العلاقة بين جودة الحياة و الميول المهنية، لدى أطفال المؤسسات الإيوائية وأقرانهم الذين يعيشون مع أسرهم. 
r - التعرف على الفروق في الميول المهنية بين أطفال المؤسسات

$$
\text { الإيوائية وبين أقرانهم الذين يعيشون مع أسرهم. }
$$

r - التعرف على ترتيب الميول المهنية لدى أطفال المؤسسات، ولدى الدى لين

$$
\begin{aligned}
& \text { أقرانهم الذين يعيشون مع أسرهم. } \\
& \text { أهمية الدراسة: } \\
& \text { تتمثل أهمة الدراسة في: لهمئه }
\end{aligned}
$$

1 - النتبيه على ضرورة الاهتمام بجودة الحياة النفسية لأطفال المؤسسات النية

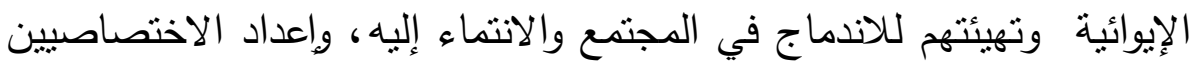
الاجتماعيين والنفسانيين لتقديم المساعدة والمساندة الاجتماعية والنفسية لهؤلاء

r - توجيه نظر المسئولين التربويين إلى أهمية التوجيه والإششاد المهني أثناء مراحل الدراسة للأطفال عامة وأطفال المؤسسات الإيوائية خاصة. r - قد تسهم نتائج هذه الدراسة في توجيه نظر الباحثين إلى أهمية إعداد

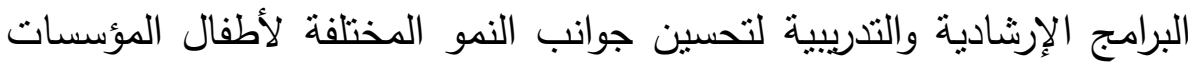
الإيوائية، لدمجهم دمجا حقيقيا في المجتمع.

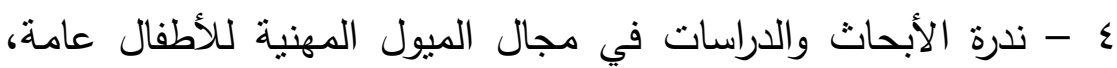
وأطفال المؤسسات الإيوائية خاصة. المصطلحات الإجرائية للاراسة والخلفية النظرية:

جودة الحياة: Quality of life

مفهوم جودة الحياة من المفاهيم متعددة الأبعاد يختلف من فرد إلى آخر ، وفق إدراكه لجوانب حياته ووصفه لظروفها، وقد كثرت التعريفات وتعددت، ومن أكثرها شيوعا وشمولا تعريف منظمة الصحة العالمية، حيث يعبر عن مضامين معظم التعريفات، وتعرفه على أنه:إدراك الفرد لوضعه في الحياة في سياق النقافة وأنساق القيم التي يعيش فيها ومدى تطابق أو عدم تطابق ذلك مع: أهدافه، 
وتوقعاته، وقيمه، واهتماماته المتعلقة بصحته البدنية، وحالته النفسية، ومستوى استقلاليته، وعلاقاته الاجتماعية، واعتقاداته الثخصية، وعلاقته بالبيئة بصفة وهنه عامة. (WHOQOF Group,1995, 1404) ويذهب كريج جاكسون Jackson, 2010 إلى وسلى أن جودة الحياة ليست فقط سعادة الفرد أو خلوه من الأمراض، أو امتلاكه

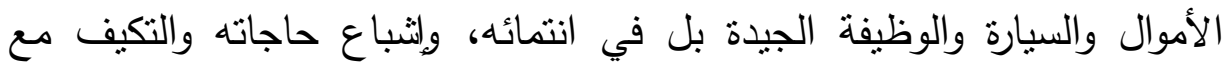
البيئة، والإحساس بالمتعة والحرية والمرونة، وتحقيق الهوية والإثباع الروحي

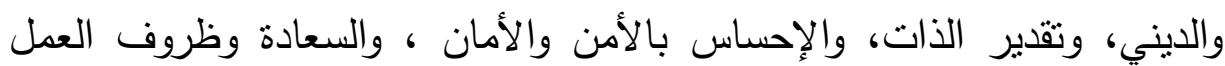

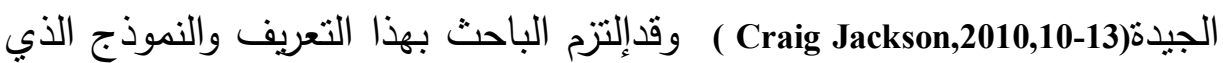
وضعه كريج جاكسون لجودة لحياة.

Residential Care: المؤسسات الإيوائية

عرف قانون الطفل الصادر عن رئاسة جمهورية مصر العربية في مارس 9997 المؤسسات الإيوائية بأنها كل دار لإيواء الأطفال الذين لا تقله سنهم عن ست سنوات ولا يزيد عن ثماني عثرة سنة، والمحرومين من الرعاية الأسرية بسبب اليتم أو تصدع الأسرة أو عجزها عن توفير الرعاية الأسرية

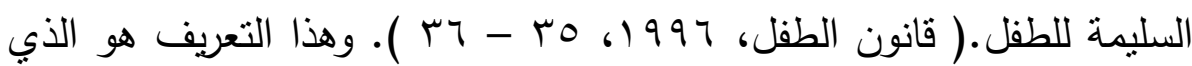
اعتمدت عليه الدراسة الحالية.

الميول المهنية: Vocational interests

يعرف الميل المهني بأنه المجموع الكلي لاستجابات القبول التي يبديها

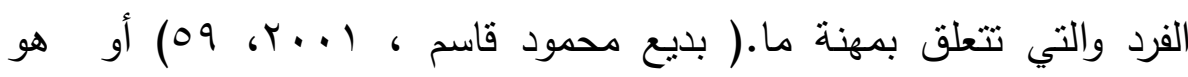

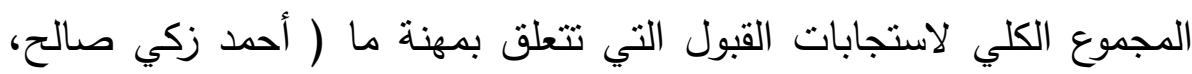

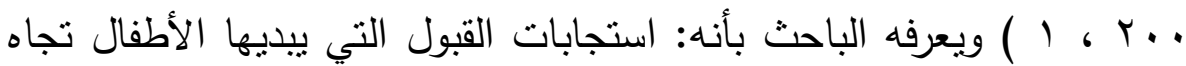
مجموعة من الأنشطة تتعلق بمهنة ما قد يزاولها في المستقبل، و تتمثل في لبهن مجموع الدرجات التي يحصل عليها الطفل في المقياس المستخدم.

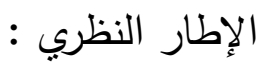


أولا : جودة الحباه:Quality of life

استخدم مفهوم جودة الحياة في العديد من العلوم، حيث بستخدم أحيانا للتعبير عن الرقي، ومستوى الخدمات المادية والاجتماعية التي تقدم لأفراد المجتمع، كما يستخدم للتعبير عن إدراك الأفراد لمدى قدرة هذه الخدمات على إثباع حاجاتهم المختلفة، و لا يرتبط هذا المفهوم بمجال محدد من مجالات الحياة، أو بفرع معين من فروع العلم،إنما هو مفهوم موزع يبن الباحثين والعلماء على اختلاف تخصصاتهم والملفت للنظر أن أصحاب كل تخصص يرون أنهم الأحق باستخدام هذا المفهوم سواء كان هؤلاء تخصص علم الاجتماع، أو الطب بفروعه المختلفة، أو العلوم البيئية أو الاقتصادية.( عادل الأشول، $(r, r . .0$

وظهر مفهوم الجودة في الصناعة، ثم انتشر بين كافة المجالات، وقد عرفه الباحثون في ضوء تخصصاتهم العلمية، الأمر الذي أدى إلى تعدد وجهات النظر التي تتاولت هذا المفهوم. وقد ظهر المصطلح في القاموس الطبي عام ؟19 ا بعد تعربف المنظمة العالمية لمفهوم الصحة عام 9 V 1، والذي يربط مفهوم الصحة ببعض الأبعاد الاجتماعيـة والنفسية الضـرورية لحياة الفرد، وأصبح يفهم بصسورة ذاتبـة تختلف من شخص لآخر وتتأثز بالتصورات التقافية والاجتماعية والدينيه.

وينبغي الاشارة إلى أن مفهوم جودة الحياة المرتبط بالصحة عرف تدرجا وتطورا مهما ليرتبط بالحركة والنشاط اليومي؛ إذ ربط المختصون بين الإعاقة الحركية وجودة الحياة ، وفي نهاية الثمانينات زاد الاهتمام بالبعد العقلي في مفهوم جودة الحياة من خلال الاهتمام بالقدرات العقلية ،ثم الآثار والتعقيدات المترتبـة عليها فيمـا بعـد، والتـي أثـارت إلىى مشـكلة فقدان الاسـتقلالية ،كمـا تواصـل تطـور الدراسات حول الأعراض النفسية وبدأ الاهتمام بجودة الحياة المرتبطة بالسرطان 
وجراحة القلب وأثر المرض على المحيط الأسري، كما ظهر اتجاه آخر ركز

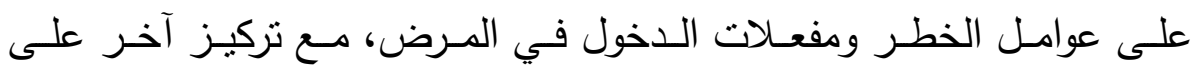

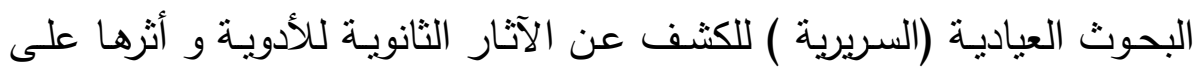
. ءات الوظيفي الكف

وخلال التسعينيات وجه الاهتمام للتركيز على الجوانب الذاتيـة للصحة بإدماج

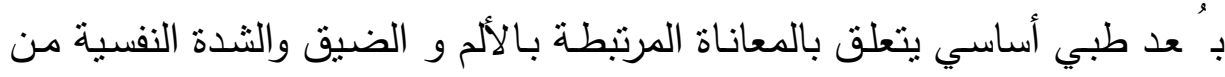

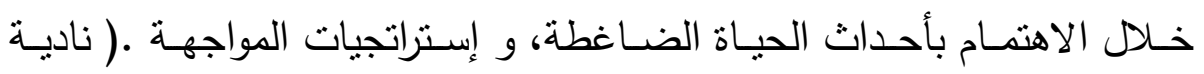

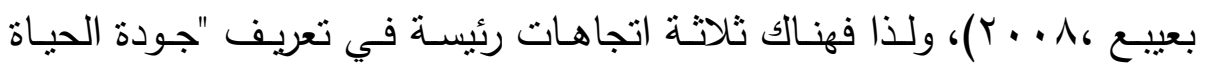

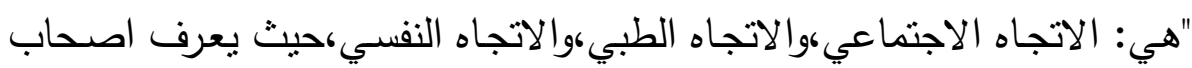

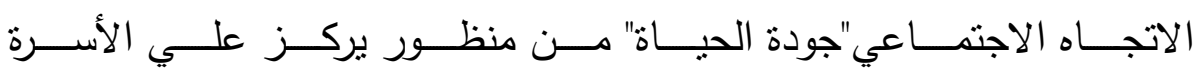

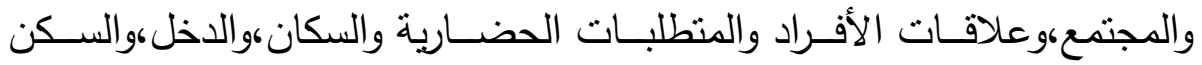
والمتغيرات الاجتماعية الأخرى.وتعتبر منظمة اليونسكو هذا المفهوم شاملا لكل

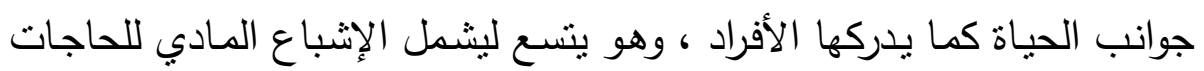

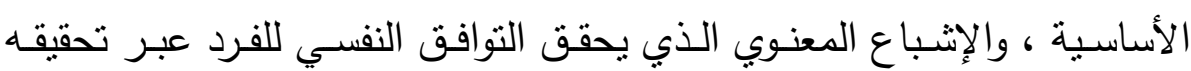

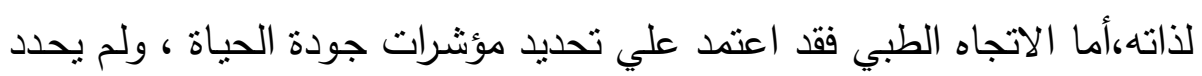

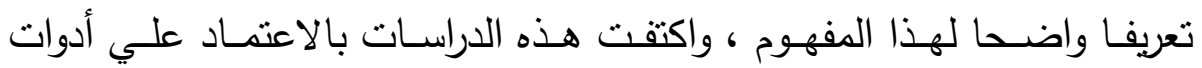
خاصـة لقياس المفهوم من منظور الصحة والمرض.بينما ركز الاتجاه النفسي علي إدرالك الفـرد كمحدد أساسي للففهوم وعلاقـة المفهوم بالمفــاهيم النفسـية

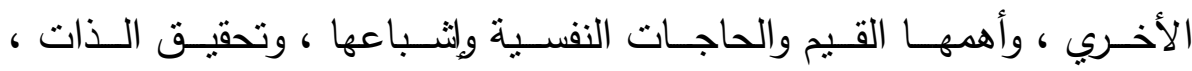

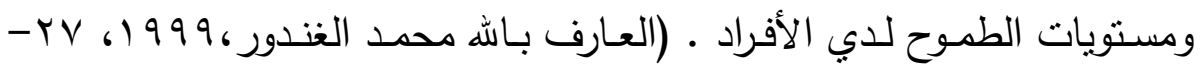

ويرى كومنس Cummins, 1997 أن مفهوم جودة الحياة يشير إلى الصحة الجيدة أو السعادة، أو تقدير الذات، أو الرضا عن الحياة، أو الصحة النفسية. - (Cummins,1997, 117, 
وعادة ما يتم تعريف مفهوم جودة الحياة في ضوء بعدين أساسيين لكل منهما مؤشرات معينة: البعد الذاتي، والبعد الموضوعي. إلا أن غالبية الباحثين ركزوا على المؤشرات الخاصة بالبعد الموضوعي لجودة الحياة. ويتضمن البعد الموضوعي لجودة الحياة مجموعة من المؤشرات القابلة للملاحظة والقياس المباشر مثل: أوضاع العمل، مستوى الدخل، المكانة الاجتماعية الاقتصادية، وحجم المساندة المتاح من شبكة العلاقات الاجتماعية. Bishop, \& Feist-Price, وحنة

وتعرف أيضا بأنها وعي الفرد بتحقيق التوازن بين الجوانب الجسمية

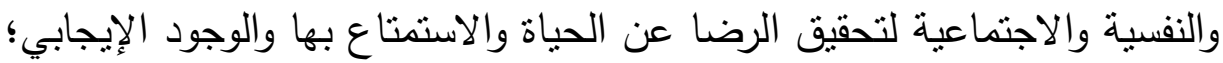
فجودة الحياة تعبر عن التوافق النفسي كناتج لظروف المعيشة الحياتية للأفراد وعن الإدراك الذاتي للحباة، لكون هذا الإدراك يؤثر على تقييم الفرد للجوانب الموضوعية للحباة كالتعليم والعمل ومستوى المعيثة والعلاقات الاجتماعية من الإنا ناحية، وأهيو هذه الموضوعات بالنسبة للفرد في وقت معين وظروف معينة من

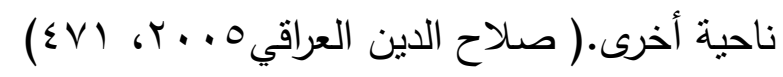
ويرى ليتمان،Litman,1999 ، أنه يجب النظر إلى مفهوم جودة الحياة من خلال الإحساس بالرفاهية والرضا ، الذي يشعر به الفرد في ظل ظروفه الحياتية.

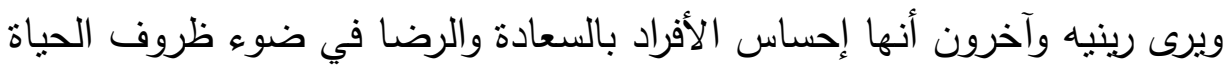

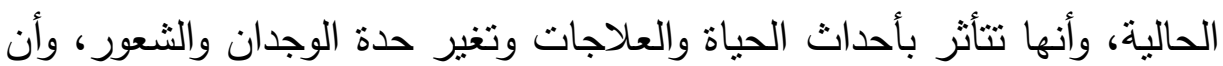

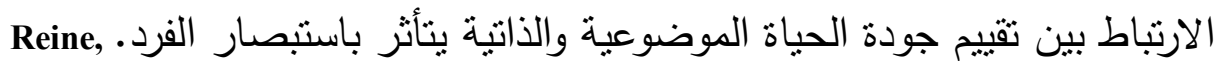

(et al,2003, 297) وتتحد جودة الحياة من خلال قوى داخلية وخارجية، فإحساس الفرد بالسعادة يكون معتمدا على الخصائص الموضوعية للموقف، وتتمنل العوامل الذاتية المؤثرة في جودة الحياة في مستوى الطموح ، والخبرة، والتوقعات الثخصية والإدراك للظروف لإن الحالية، كما تتأثر بمستوى الموارد والضغوط البيئية. (Rossler,1990,3 
ويرى جليمان وأخرون ع ـ Gilman, et al Y أن تحليل نتائج الدراسات السابقة في مجال جودة الحياة يفضي إلى التأكيد على أن جودة الحياة بالمعنى الكلي أو العام تتظم وفقًا لميكانيزمات داخلية، وبالتالي يتعين على الباحثين التركيز على المكونات الذاتية لجودة الحياة بما تتضمنه من التقرير الذاتي عن:

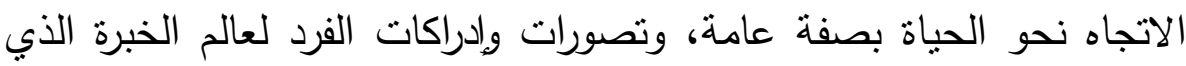
يتفاعل فيه، ونوعية ومستوى طموحاته( Gilman, et al, 2004) .

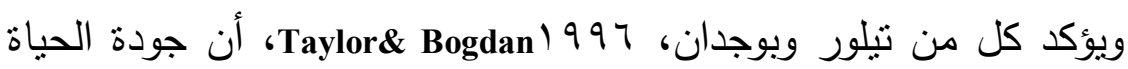

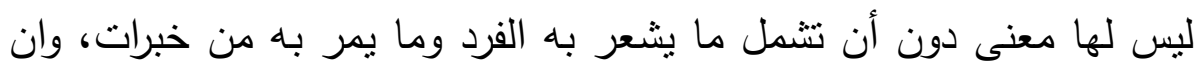

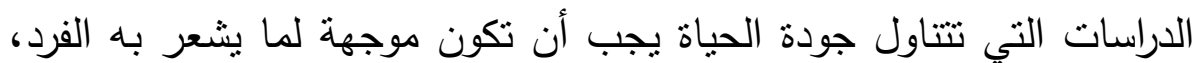

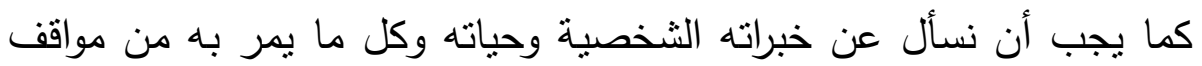

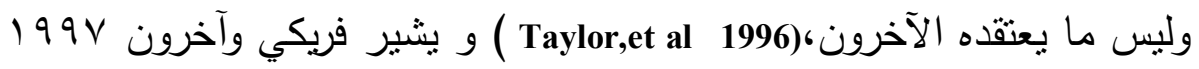
Vreeke, et al

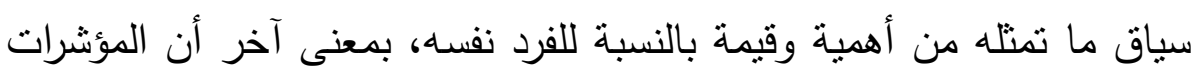

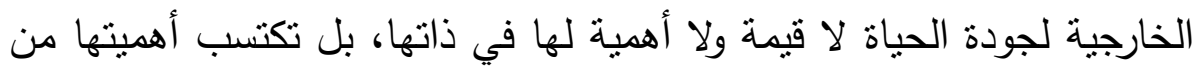

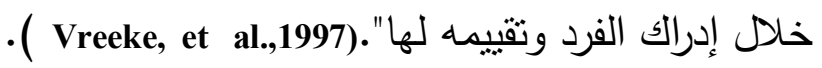
وعلى الرغم من عدم الاتفاق على تعريف واحد لمفهوم جودة الحياة، إلا أنه النه عادة ما يشار في أدبيات المجال إلى تعريف منظمة الصحة العالمية (1990 (19 )

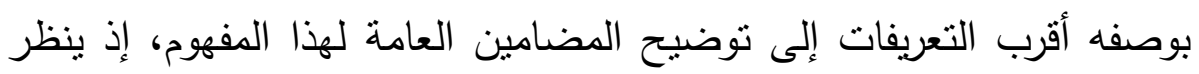

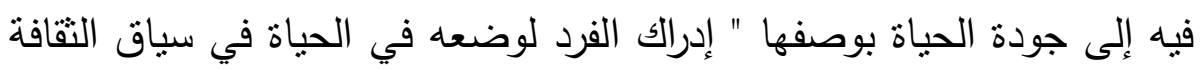
وأنساق القيم التي يعيش فيها ومدى تطابق أو عدم تطابق ذلك مع: أهدافه،

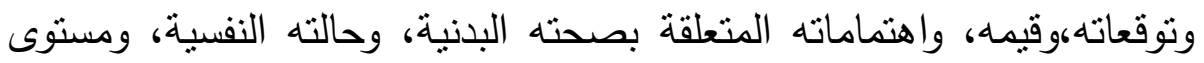
استقلاليته، وعلاقاته الاجتماعية، واعتقاداته الثخصية، وعلاقته بالبيئة بصفة ولهة ولهانه عامة، وبالتالي فإن جودة الحياة بهذا المعنى تشير إلى تقييمات الفرد الذاتية لظروف حياته".(WHOQOL Group, 1995,1404) 


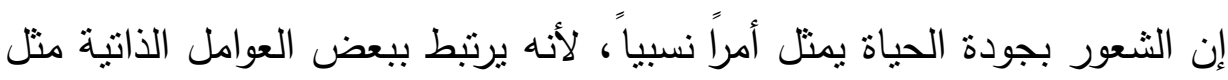

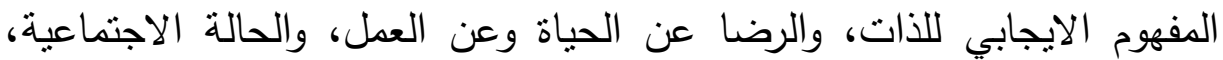

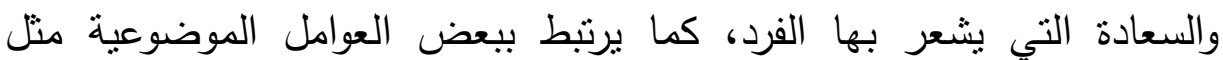
الإمكانيات المادية الدتاحة، والدخل، ونظافة البيئة، والحالة الصحية، والحالة السكنية والوظيفية، ومستوى التعليم، وغير ذلك من العوامل التي تؤثر في الفرد.

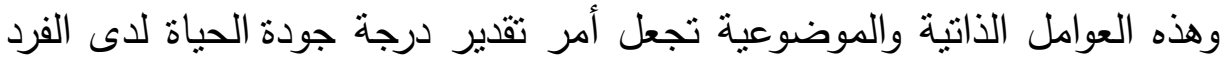

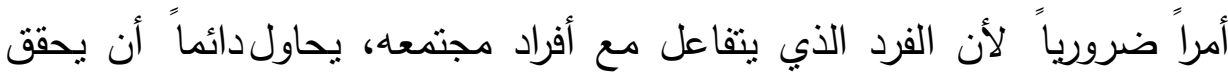

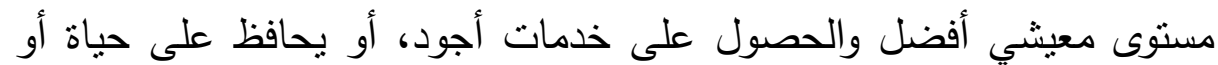
مستوى معيشي لا يقل عن مستوى الحياة التي كان يعيشها في الماضي.ولكن

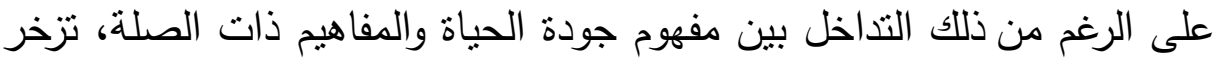
الأدبيات النفسية بعدد من التعريفات، منها أن جودة الحياة "هاني: الهي:

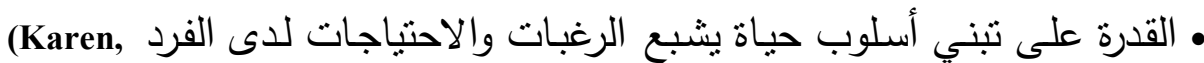
Lambour, \& Greenspan, 1990).

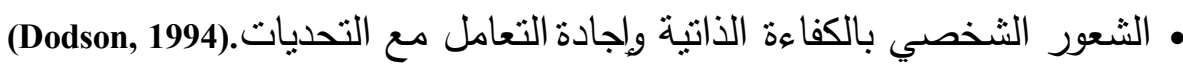

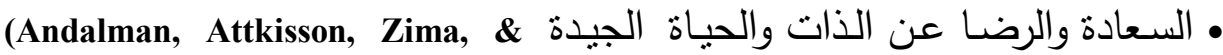

Rosenblatt, 1999). • رقي مستوى الخدمات المادية والاجتماعية التي تقدم لأفراد المجتمع، والنزوع

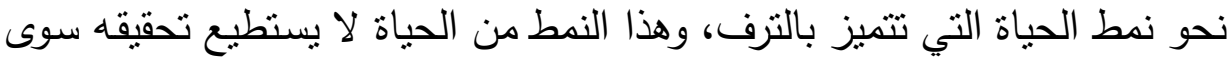

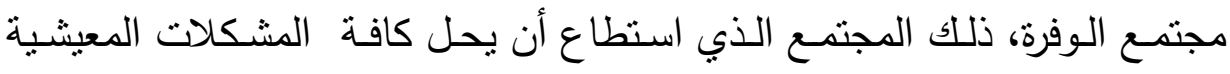

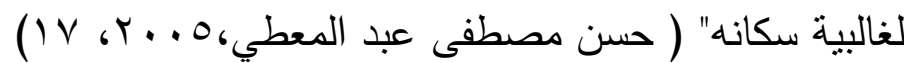

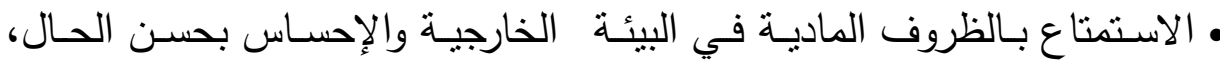
ولثثباع الحاجات، والرضا عن الحياة، وادراك الفرد لقوى ومضامين حياته وشعوره

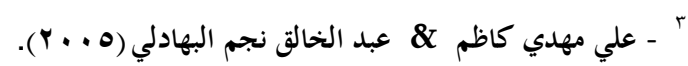


بمعنى الحياة إلى جانب الصحة الجسمية الايجابية وإحساسه بالسعادة وصولا إلى عيش حياة متتاغمة متوافقة بين جوهر الإنسان والقيم السائدة في مجتمعه" (فوقية

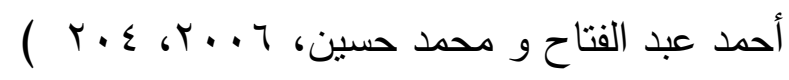

• "درجة إحساس الفرد بالتحسن المستمر لجوانب شخصيته في النواحي النفسية،

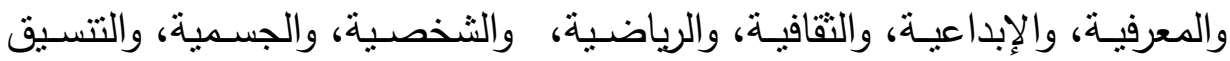
بينها، مـع تهيئة المنـاخ المزاجي والانفعالي المناسبين اللعدل والإنجاز ، والتعلم

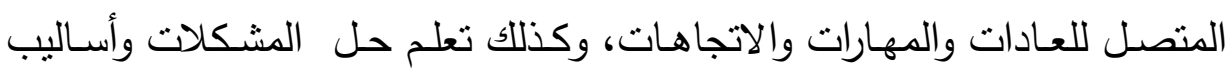
التوافق والتكيف، وتنني منظور التحسن المستمر للأداء كأسلوب حياة، وتلبية الفرد

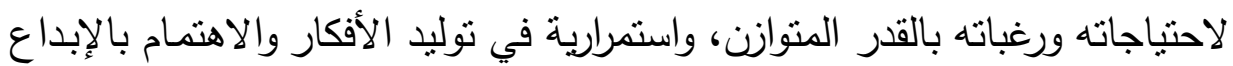

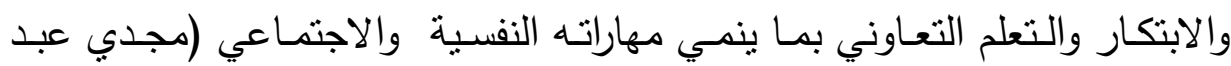

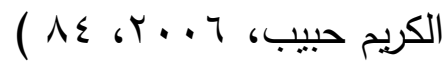
• "حالة شعورية تجعل الفرد يرى نفسه قادر على إثباع حاجاته المختلفة (الفطرية

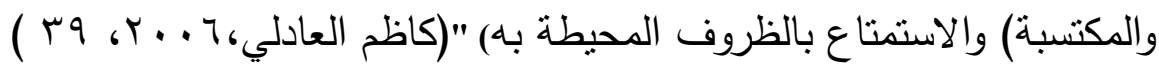
• شعور الفرد بالرضا والسعادة والقدرة على إثباع حاجاته من خلال ثراء البيئة ورقي الخدمات التي تقدم له في المجالات الصحية والاجتماعية والتعليمية والنفسية مـع حسن إدارته للوقت والاستفادة منهه" ( محمود عبد الحليم منسي وعلي مهدي

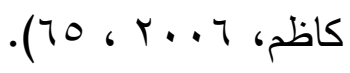

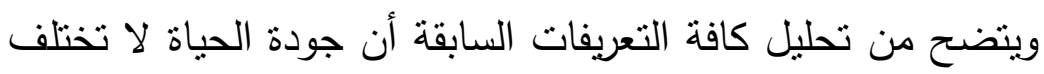

عن وصف كرييج جاكسون، Craig A. Jackson ، والمصاغ تحت مسمى 2010 الثلاثة بي The 3 B's وهي على النحو التالي: الكينونة Being : ويقصد بها القدرة البدنية وممارسة الأنشطة الحركية، وأساليب التغذية وأنواع المأكولات.الانتماء Belonging : ويعني به ادرالك الفرد وحبه للمكان الذي يعيش فيه، ونطاق الجيرة،

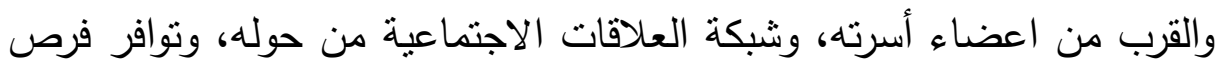
الحصول على الخدمات المختلفة. الصيرورة Becoming : ويعني بها: القيام 
بدور فعال في البيئة، والالتحاق بعمل أو الذهاب للمدرسة، والأنشطة الترفيهية ؛

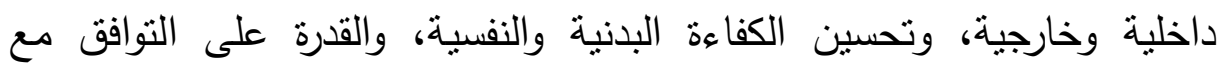
متغيرات الحياة.

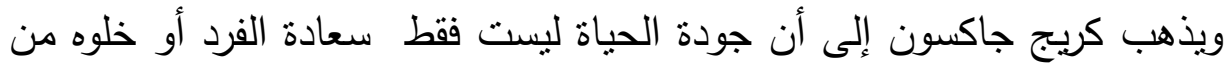
الأمراض، أو امتلاكه الأموال والسيارة والوظيفة الجيدة بل في في انتهاءة النمائه، ولثباع حاجاته والتكيف مع البيئة، والإحساس بالمتعة والحرية والمرونة، وتحقيق الهوية

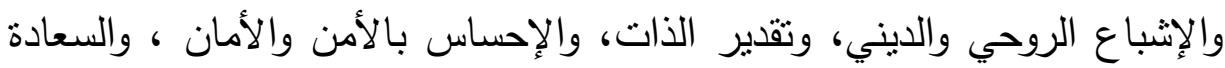

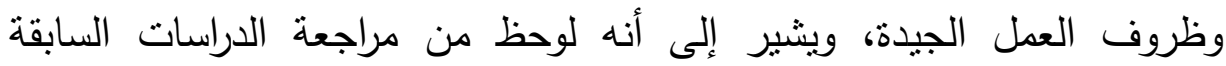
انخفاض جودة الحياة عند الأطفال المساءة معاملتهم، ومرضى التهاب الكبد والوبائي ، ومرضى التهاب المفاصل، والمرضى الذين يعانون من الالتهابات الليمفاوية، ووضع نموذجا يوضح فيه كيفية الوصول إلى جودة الحياة، من خلال

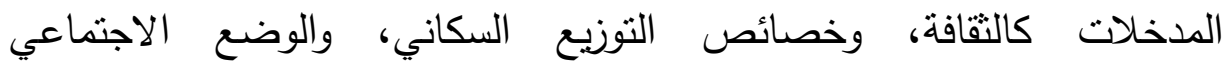
/الاقتصادي، تلك المدخلات التي تساعد الفرد على أن يدرك مكانته في الحياة

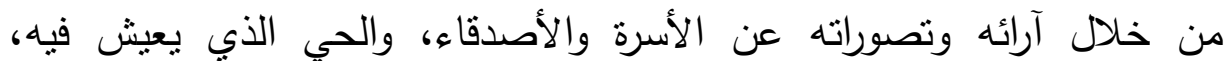
والمسكن، والعمل، والتعليم، والقيم الدينية والروحية.شكل رقم (1) (1) ( Craig ) Jackson,2010,10-13 


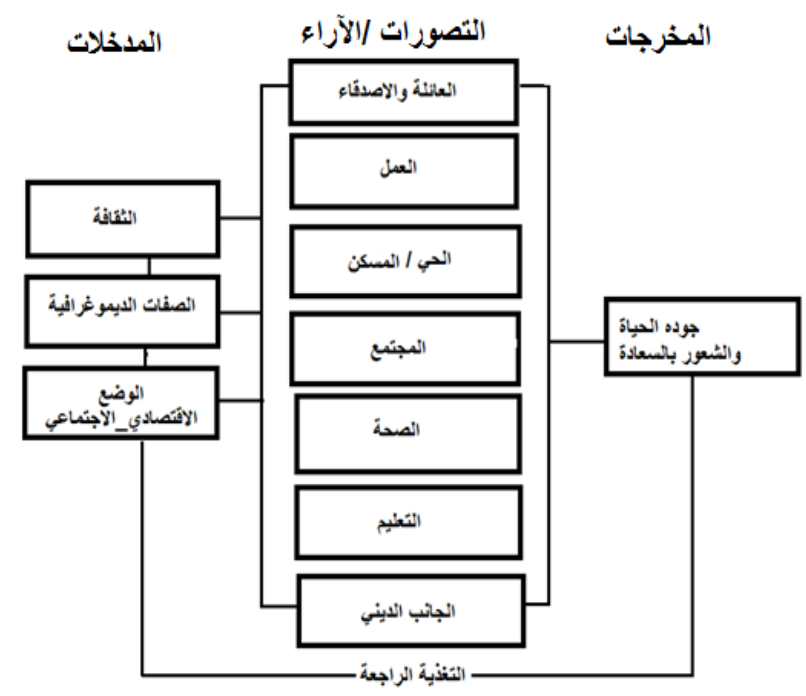

شكل رقم ( ) يبين نموذج كريج جاكسونCraig Jackson لجودة الحياة وقد اعتمد الباحث جوانب جودة الحياة كما وردت في نموذجا كرييج

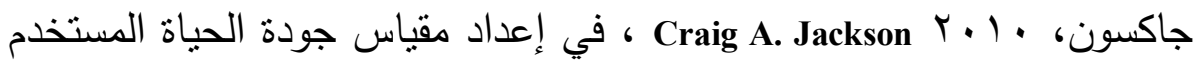

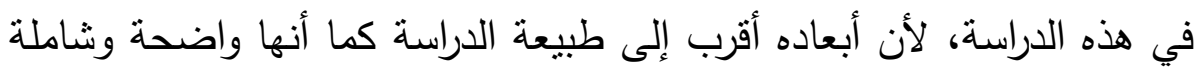

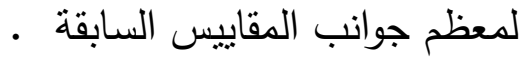
إن جودة الحياة في تحليلها النهائي "وعي الفرد بتحقق التوازن بين الجوانب الجسمية والنفسية والاجتماعية لتحقيق الرضا عن الحياة والاستمتاع بها والوجود الإيجابي. فجودة الحياة تعبر عن التوافق النفسي كما يعبر عنه بالسعادة والرضا لهاهي عن الحياة كناتج لظروف المعيشة الحياتية للأفراد وعن الإدراك الذاتي للحياة،

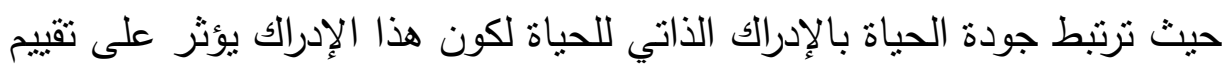
الفرد للجوانب الموضوعية للحياة كالتعليم والعمل ومستوى المعيشة والعلاقات 
الاجتماعية من ناحية، وأهمية هذه الموضوعات بالنسبة للفرد في وقت معين

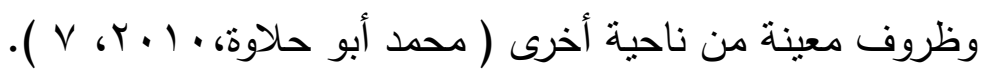

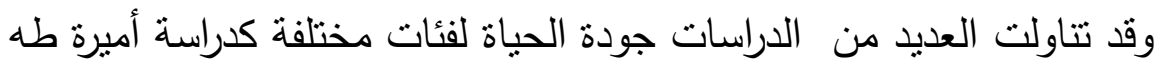
بخش 0. . ب هدفت إلى الكثف عن الفروق في جودة الحياة بين المعاقين بصريا والعاديين بالمملكة العربية السعودية، كما هدفت الدراسة إلى التعرف على العلاقة بين جودة الحياة ومفهوم الذات لدى هؤلاء العاديين والمعاقين بصريا بالمملكة

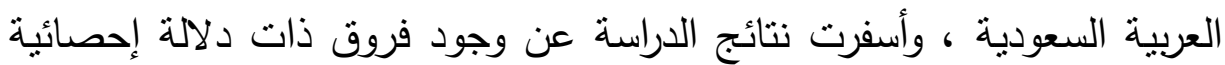

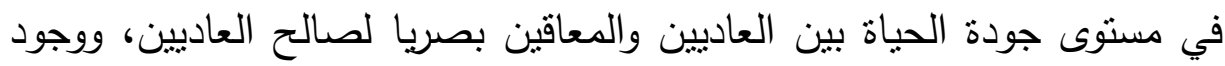
علاقة دالة وموجبة بين مفهوم الذات وجودة الحياة لدى عينة العاديين والمعاقين

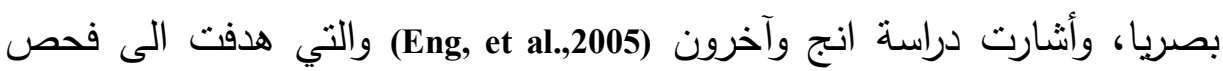
أبعاد الرضا عن الحياة لدى طلاب الجامعة الذين يعانون من اضطراب القلق وانق

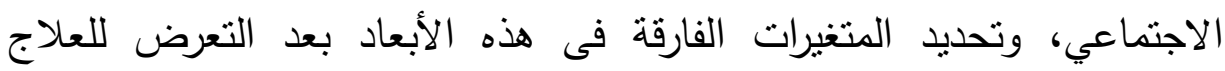
السلوكى المعرفي، الى حدوث تحسن واضح فى بعدى التحصيل الدراسي والأداء

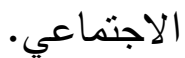

وتوصل هشام ابراهيم عبداله في دراسته عن الراشندين العاديين سنة

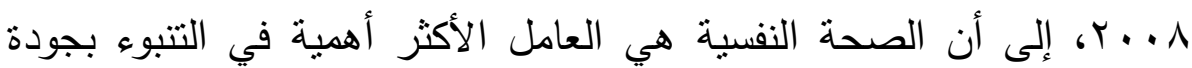

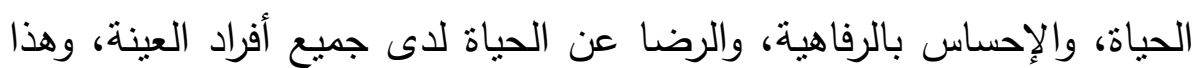
يؤكد على أهمية شعور الفرد بالصحة النفسية لتحسن قدرته على إدراك جودة الحياة، وأطفال المؤسسات في حاجة ملحة لتحسين أحوالهم الاجتماعية والنفسية، وتتمية إدراكهم لذاتهم وجودة حياتهم، وهذه مسئولية يجب أن تطلع بها

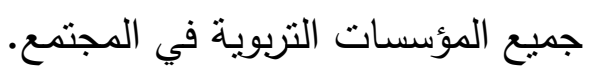

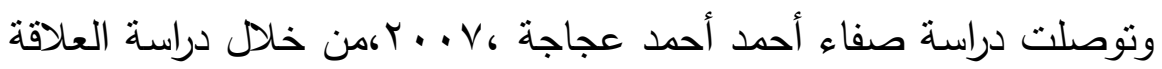
بين الذكاء الوجدانى وجودة الحياة لاى طلاب الجامعة ، ودراسة العلاقة بين

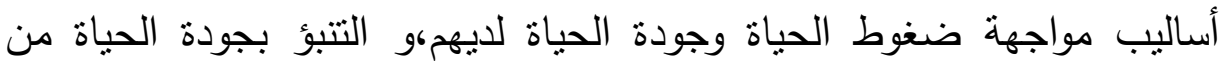


خلال بعض ابعاد الذكاء الوجدانى و بعض أساليب مواجهة الضغوط ، إلى وجود علاقة ارتباطية ذات دلالة احصائية موجبة عند ا ب,., بين الدرجة الكلية للذكاء

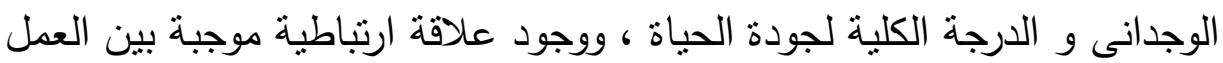

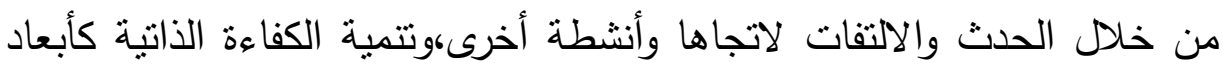
أساسية لأساليب المواجهة، و بين الدرجة الكلية لجودة الحياة ، كما تثير دراسة

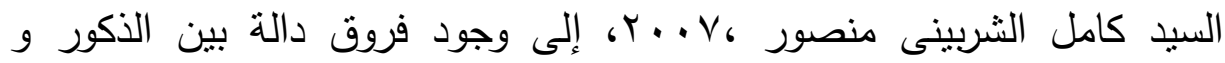

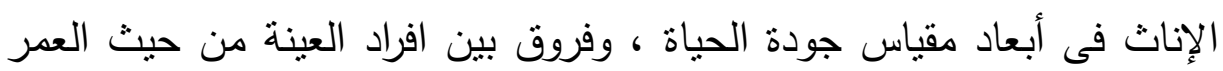

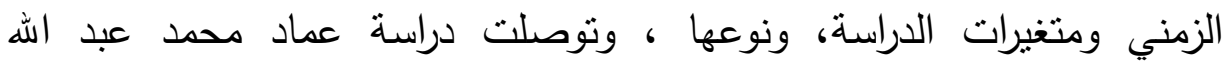

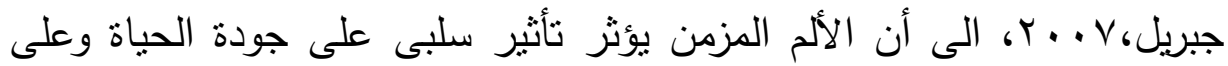

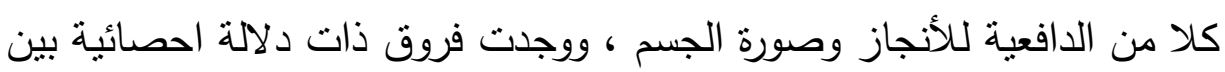
فئتى مرضى الألم المزمن ومجموعة الاصحاء فى جودة الحياة ودافعية الإنجاز

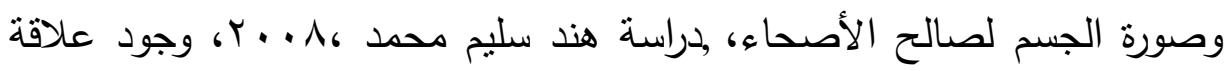
ارتباطية سالبة بين الرهاب الأجتماعى وجودة الحياة لدى طلاب المرحلة الثانوية

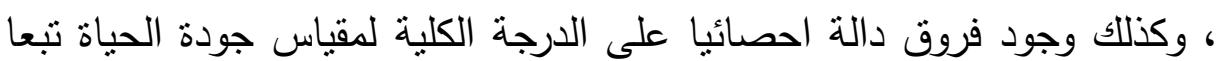

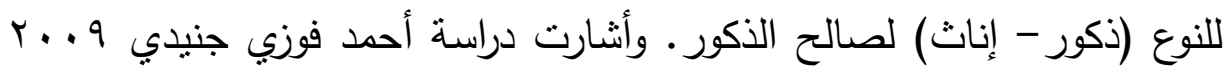
إلى فعالية البرامج الإششادية في تحسين جودة الحياة النفسية للأطفال الموهين

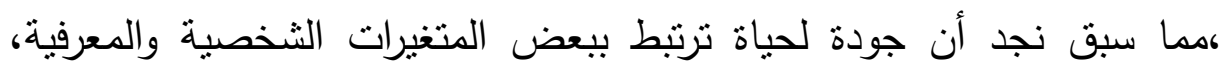
بالحالة المرضية للفرد، والمشكلات السلوكية، و والذكاء الوجداني، والمخاوف، لهنيط

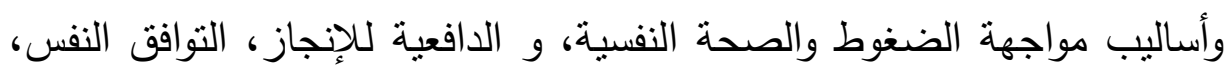
وقد أثنارت الكثير من الدراسات إلى أن أطفال المؤسسات لديهم الكثير من والنه

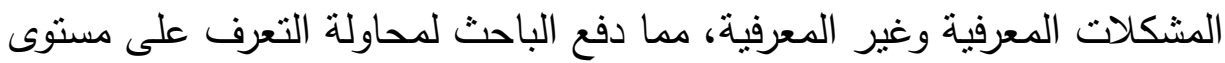
جودة حياة هؤلاء الأطفال وعلاقتها بميولهم المهنية مقارنة بأقرانهم الين يعيشون

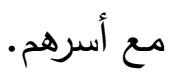


أطفال المؤسسات الإيوائية:

هم الأطفال الذين لا نقل سنهم عن ست سنوات ولا يزيد عن ثماني عشرة سنة، والمحرومون من الرعاية الأسرية بسبب اليتم أو تصدع الأسرة أو عجزها لأهن

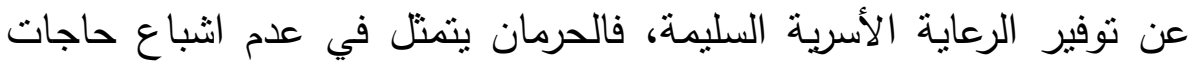

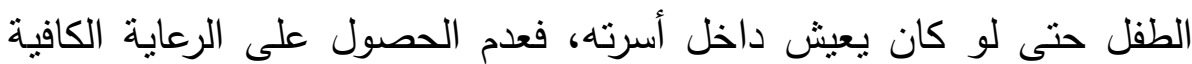
سواء كانت مادية أو عاطفية كالحب والحنان والاهتمام يعتبر حرمانا، فالحرمان لا يتوقف عند فقد الأبوين أو تخلى احدهما أو كلاهما عنه؛ إنما بمتن ليشمل

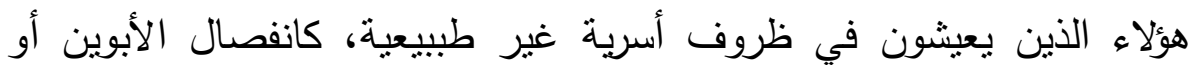
مرضهما، او عدم أهليتهم لرعاية طفلهما.

وينظر معجم التتمية الاجتماعية - الصادر عن جامعة الدول العربية - إلى الطفل الدحروم على أنه مرادف للطفل اللقيط، فيعرف الطفل المحروم بأنه : الطفل اللقيط أو المتخلى عنه الذي يولد لأب وأم غير معروفين فينبذانه للتخلص منه، أو يتركه المسؤولون عنه قانهانها : (معجم التتمية

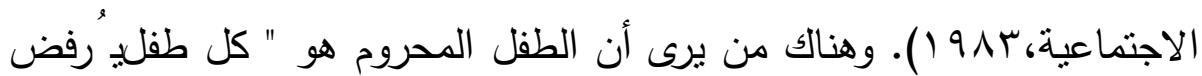

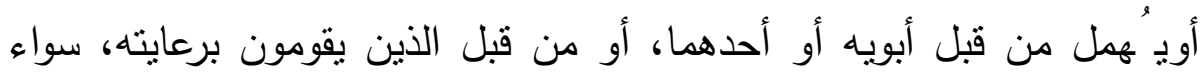

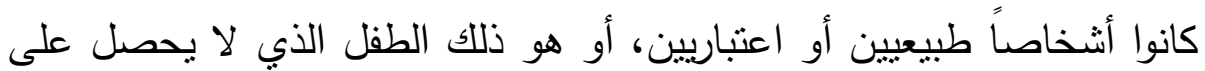

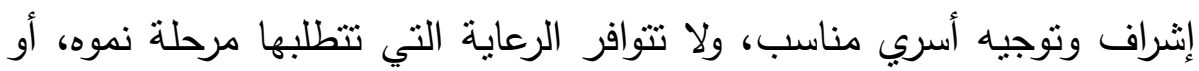

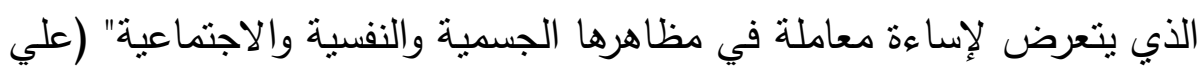
الحوات وآخرون، 919 (1، 79 (1).

وأطفال المؤسسات الإيوائية فئة من فئات المجتمع الذينيُ عُنبرون ضحايا

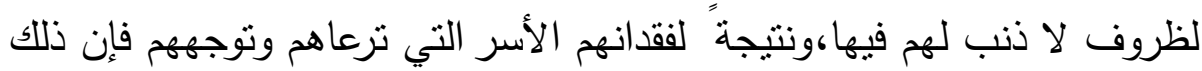

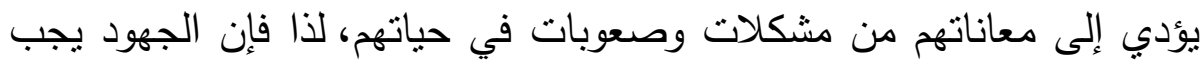

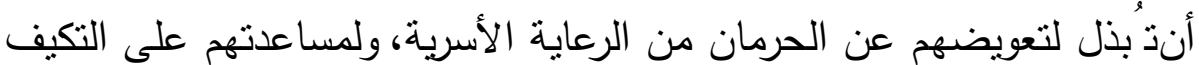
في مجتمعهم، وليكونوا أعضاء فاعلين فيه. 
إن الحرمان من الرعاية الأسرية، وما يترتب عليه من الإقامة في مؤسسات

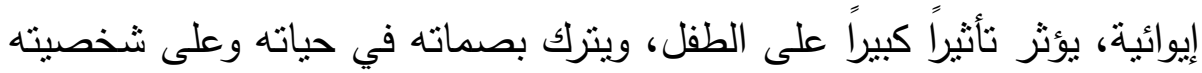

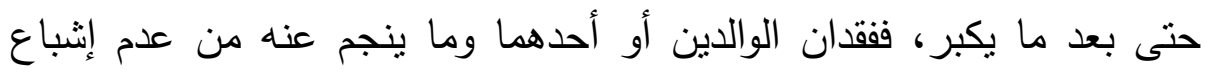

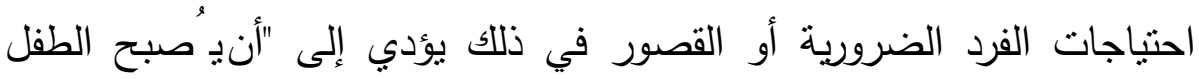

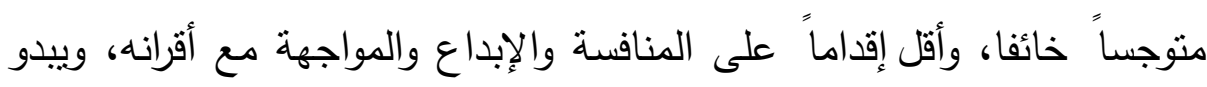

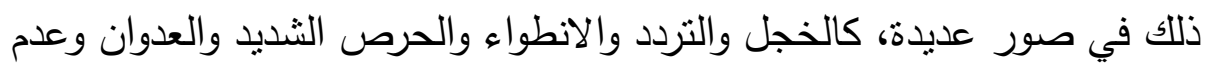
المبالاة، والعكس صحيح، فإثباع احتياجات الطفل يجعل منه شخصية إيجابية متعاونة قادرة على تحمل المسئولية والتكيف والتوافق داخل محيطه البيئي" (خيري الجميلي و محي الدين عبده، 9 ـ (9009 (19). ويحتاج الطفل إلى الرعاية الأسرية التي تعينه في حياته، وتساعده على التكيف الاجتماعي السليم، فالطفل في حاجة إلى إكسابه الثقة في النفس عن طريق إثراكه في شئون أسرته، وتهيئة الفرصة له لكي يتحمل المسئولية تدريجيًّ، ويزيد من إدراكه لجودة حياته في مراحل عمره المختلفة، وتطلعه لمستقبل أفضل يصنعه بمشاركته الفعالة في المجتمع.

إن الحياة في المؤسسات تعني نمو الأطفال في عزلة عن أسرهم وعن

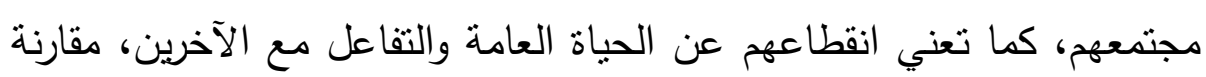
بالأطفال الآخرين، مما يؤدي إلى أضرار شديدة وطويلة الأمد على الفرد.

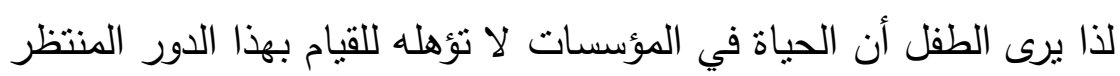
منه. وتجدر الإشارة إلى أنه، وان كان من المسلم به ثبوت أضرار للرعاية

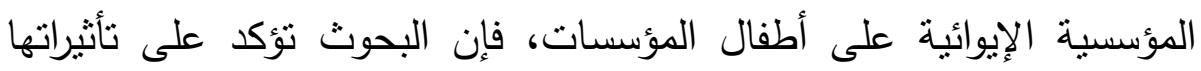

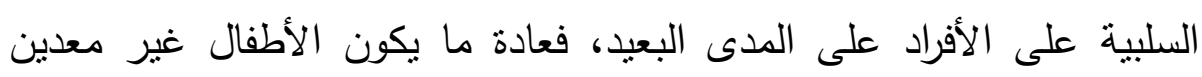

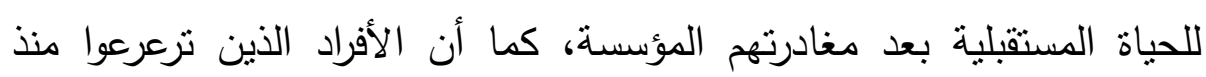

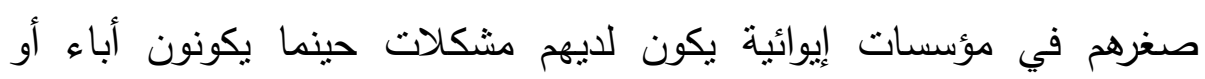

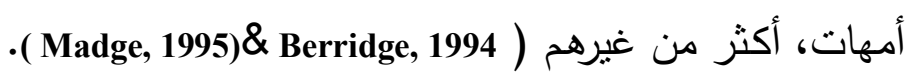


فأطفال المؤسسات بعانون من سوء التوافق الثخصي والاجتماعي، ويتمثل ذلك في عدم الشعور بالحرية وعدم الاستقالية والثعور بالنقص وانخفاض

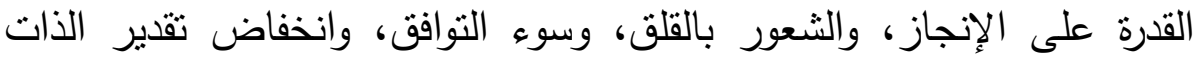

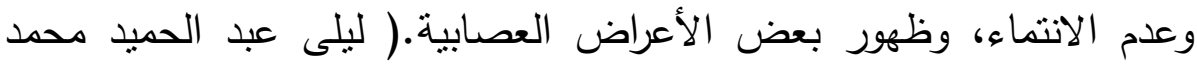

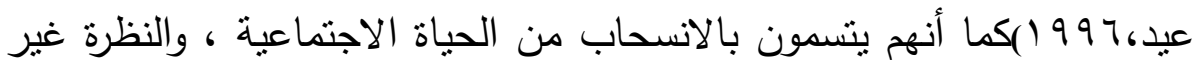

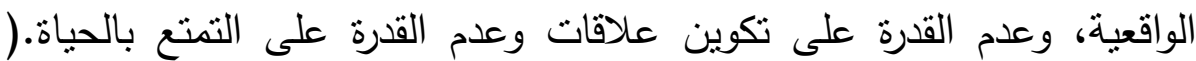

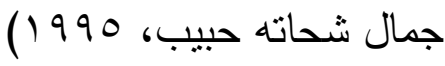
إن إدراك أطفال المؤسسات للرعاية يرتبط بنظرتهم للحباة، فالذين يدركون الرعاية سلباً ينظرون للحياة أكثر تثناؤما، مقارنة بالذين يدركونها أكثر إيجاباً.

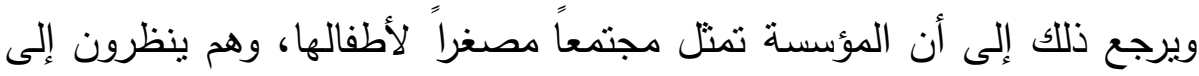

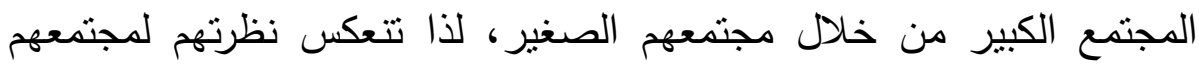
المصغر على الحياة بوجه عام، سواء كان سلبا أو إيجابا.

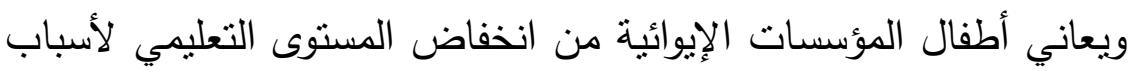

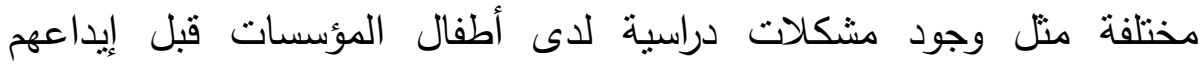
المؤسسات الإيوائية، نتيجة للمشكلات الأسرية التي يعانون منها، والتنكك

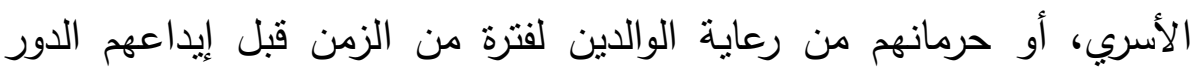
والمؤسسات. ويؤكد هيث وآخرون أهمية تأثير الحرمان والخبرات السيئة السابقة السئة

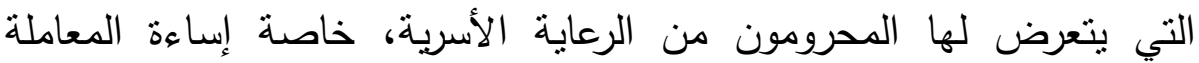
والإهمال التي تؤثر سلبياً على التحصيل الدراسي، وعلى الطفل ككل، حتى بعد التهد

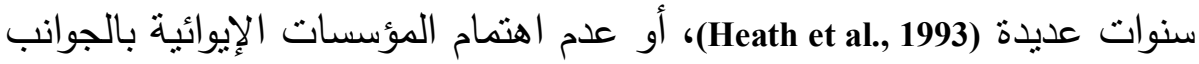
التعليمية للأطفال. كما تثير البحوث إلى أن هناك مشكلات تطليمية يعاني منها

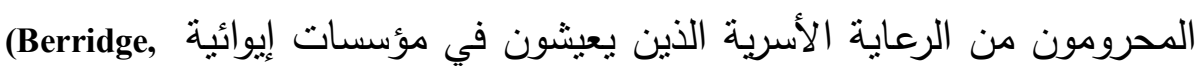
1994, Colton et al., 1991) 
إن عدم وجود القدوة، التي تتمي الطموح العلمي لدى أطفال المؤسسات

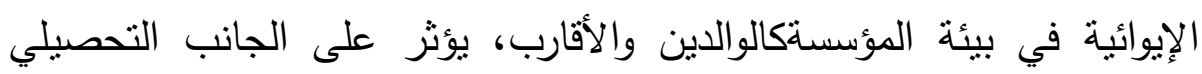
والاجتماعي والنفسي، وقد يرجع ذلك إلى سوء معاملة هؤلاء الأطفال في

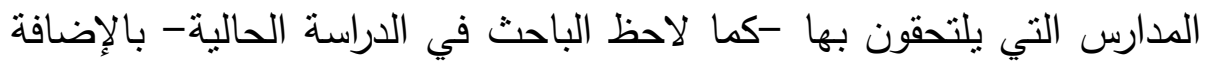

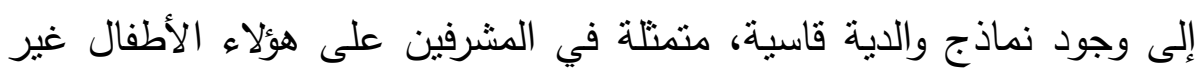

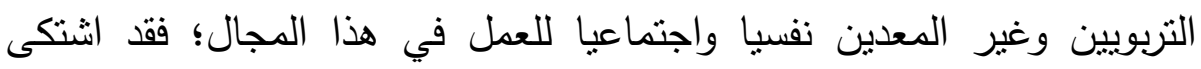
الكثير من الأطفال أثثاء المقابلات من قسوة بعض المشرفين وانئ وقياميامه بالاعتداء

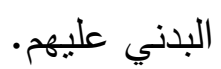

ولذا فإنه لابد من إعطاء اهتمام خاص بالأمور التعليمية لهذه الفئة بجانب الاهتمام الاجتماعي والنفسي والمهني، ويجب على الأخصائيين الاجتماعين الأبين

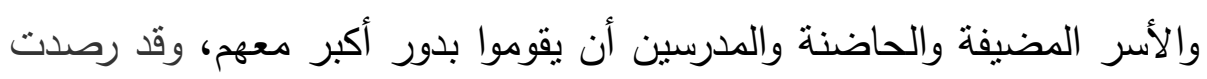

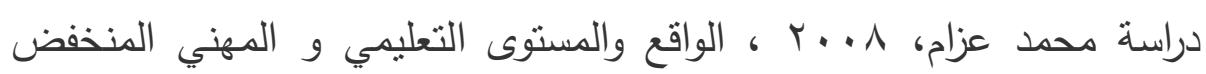

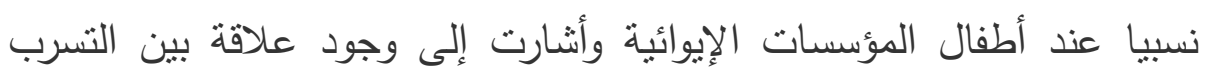

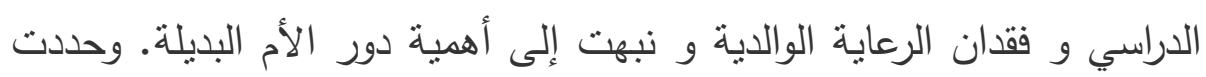

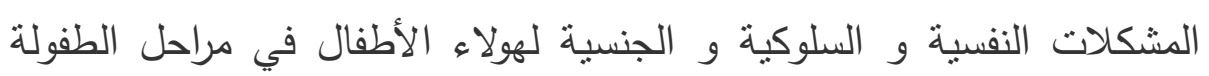

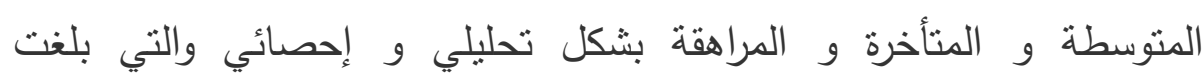
مستويات عالية تتتاسب مع الظروف القاسية التي يعيشونها في المؤسسة

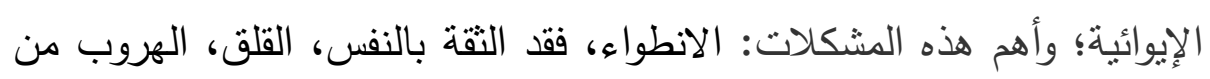

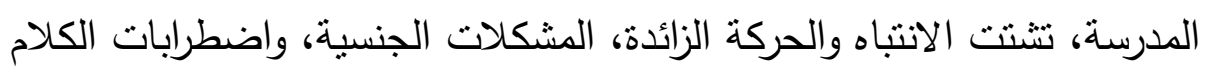
واللغة، والألفاظ البذيئة، والعدوان والكذب. لتبن.

يعتقد البعض أن المؤسسة تقوم بدور قريب لدور الأسرة الطبيعية بالنسبة ولابة

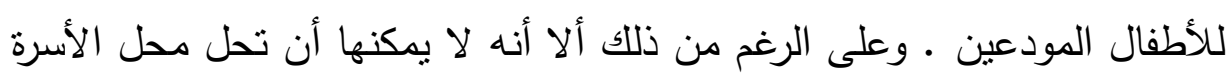

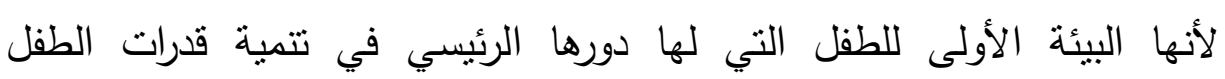

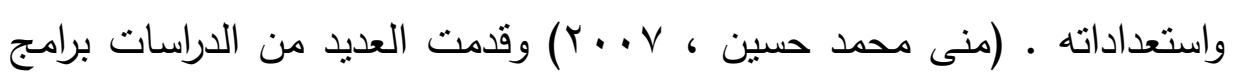
IVI 
لتخفيف حدة الاضطرابات السلوكية والعدوان لأطفال المؤسسات الإيوائية، معتمدة

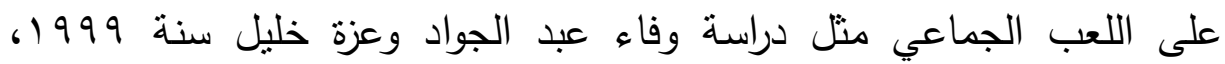
ودراسة فايزة محمد رجب بهنسي سنة ....... ودراسة ناظلك عيسى عفيفي . . . .

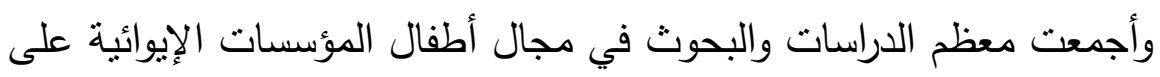
ضرورة الاهتمام بإعداد الاخصائيين الاجتماعيين والنفسانيين، والمشرفين المهنيين لتوفير حياة جيدة لأطفال هذه المؤسسات ، وتوفير مناخ جيد للتواصل وتتمية المهارات الاجتماعية، وتحسين الصحة النفسية والتوافق النفسي مما يحسن من لن هن

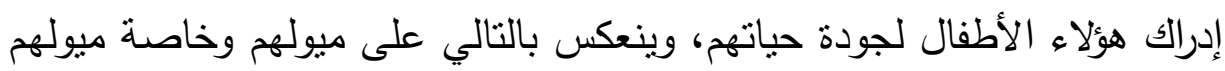

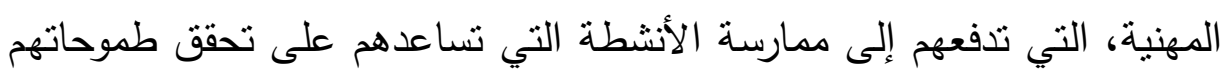

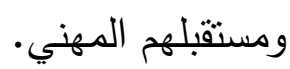

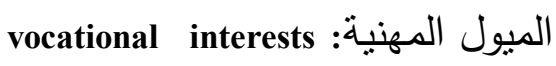
الميل المهني هو المجموع الكلي لاستجابات القبول التي يبديها الفرد والتي

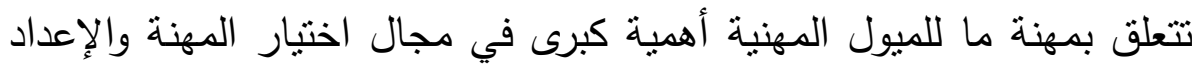

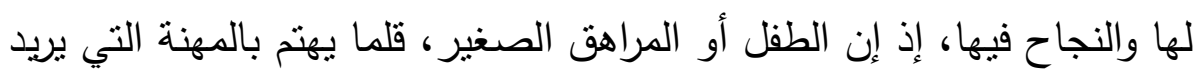

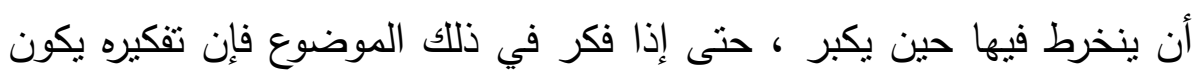

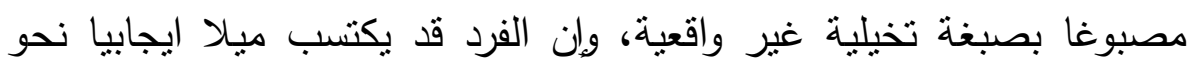

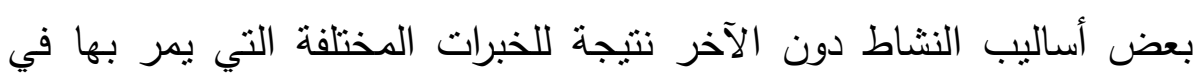

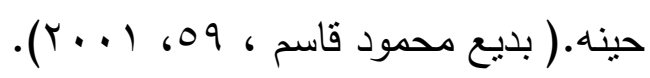

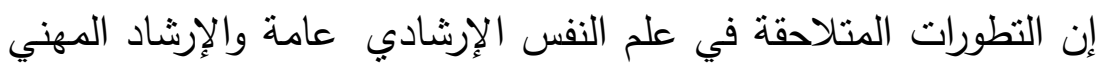

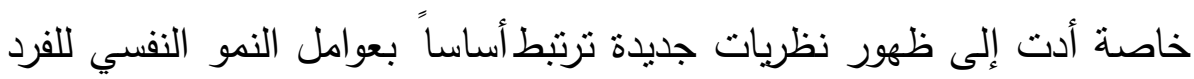

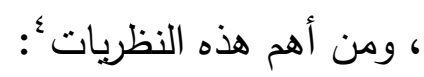

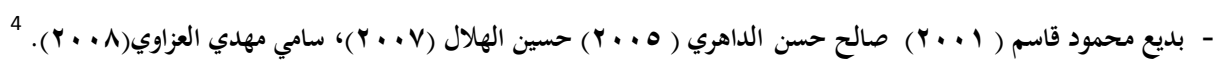


1 - نظرية جنزبرج، Ginzbers وزملائه عام 1901 : وتعتبر من المحاولات الأولى لوضع نظرية تفصيلية للنمو المهني ، تقوم على أسس ثلاثة

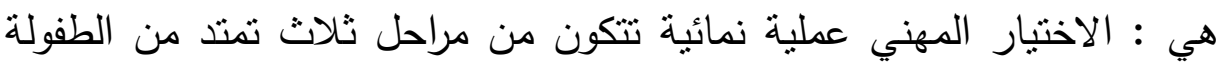
حتى الخامسة عشرة، وأن القرارات التي اتخذت في لحظة ما تؤثر في القرارات التالية ولا يمكن الرجوع فيها، والتوفيق بين جوانب متعددة هي الخاصية المميزة لكل اختيار . ، وقد قسم جينزبرج النمو المهني إلى ثلاث مراحل هي: المرحلة

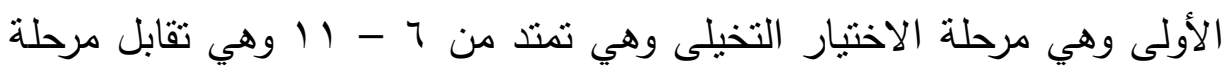
الكمون عند فرويد ، وتتميز بالاختيار العشوائي ، وقد يحققها الطفل من خلال

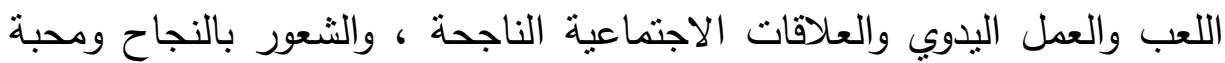

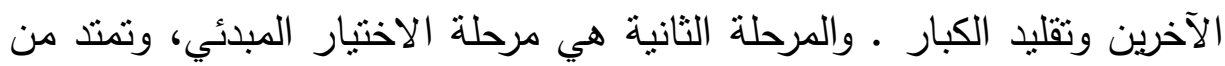

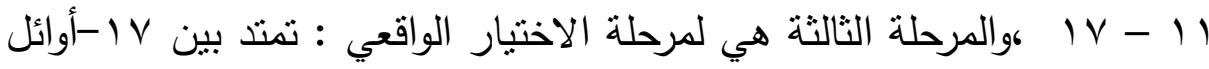

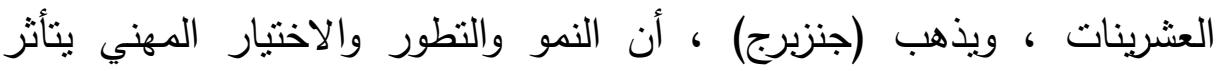

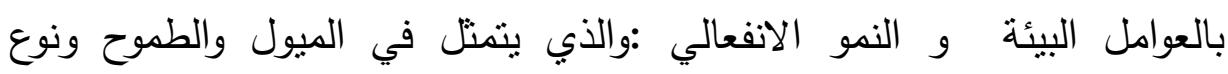

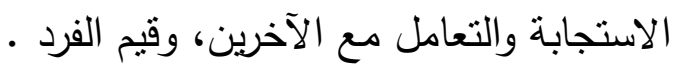

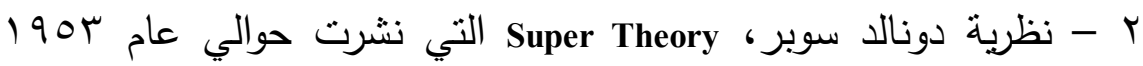
والتي ترى ان عملية النمو المهني هي عملية نمو وتكيف واكتمال لمفهوم الذات الإنسانية، بمعنى أنها توفيق بين مفهوم الذات الذي هو نتيجة التفاعل بين القدرات الموروثة والاستعدادات، وبين التكوين الفسيولوجي العصبي والغددي لهي لهين والفرص المتاحة للفرد لكي يقوم بأدوار اجتماعية متعددة ومدى نجاحه في ذلك ولكين

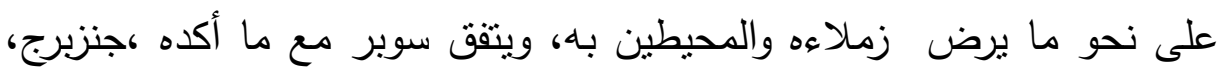

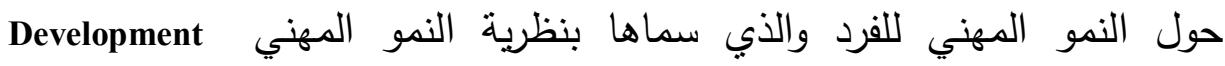
Vocational للفرد في المستويات العمرية المختلفة ـ وهذه المستويات هي : مرحلة النمو : تبدأ

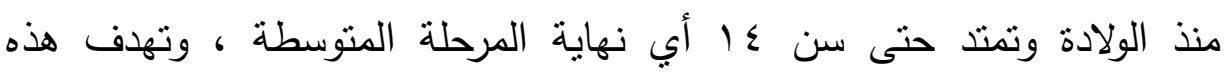
$I V T$ 
المرطلة إلى مساعدة الفرد على نحقيق مفهوم ذاته ، عن طريق القيام بأدوار

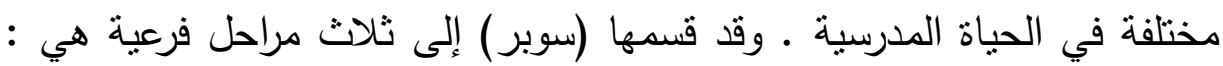

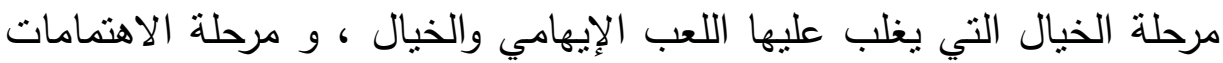

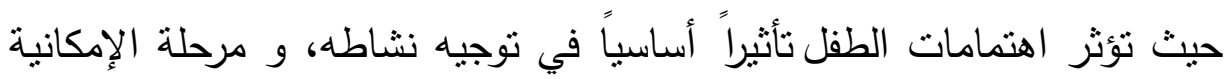

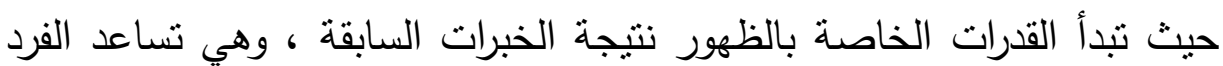
على اكتساب اتجاهات إيجابية نحو العمل ،ومرحلة الاستكثاف : وتبدأ هذه

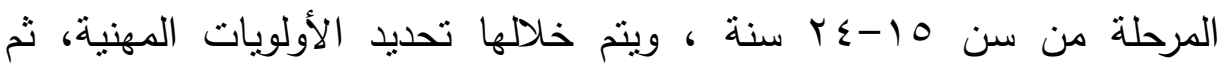

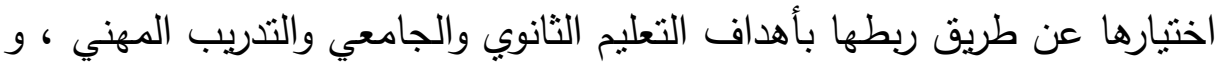

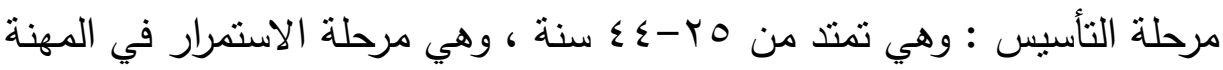

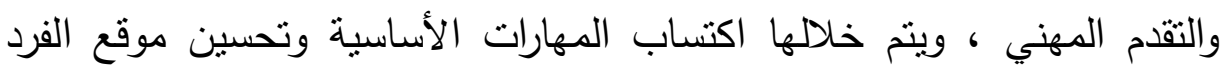

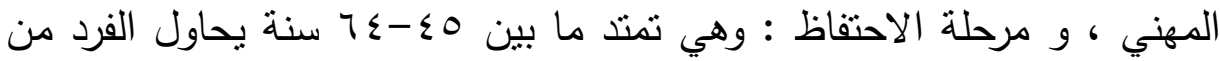
خالالها المحافظة على ما حققه واكتسبه من المهنة ، ويميل نحو عدم تغيير مهنته حيث يحقق الفرد مكانة في العمل ، ويحاول المحافظة على هذه المكانة

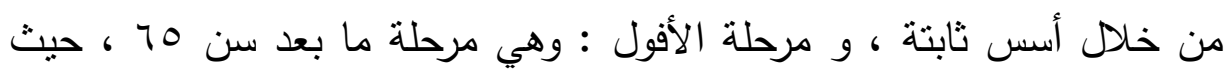

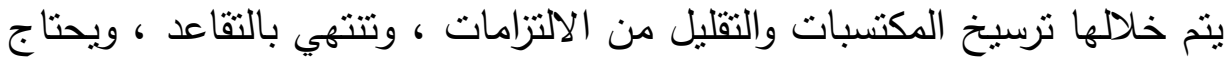

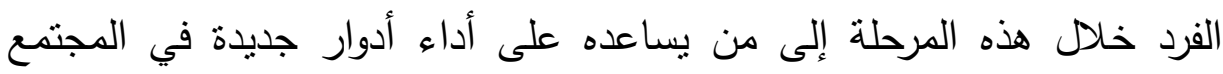
تتلاءم مع قدراته وقابلياته في هذه المرحلة العمرية .

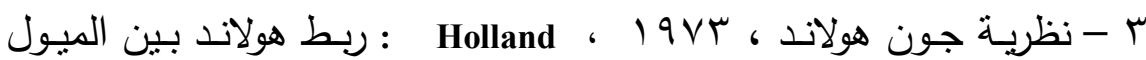

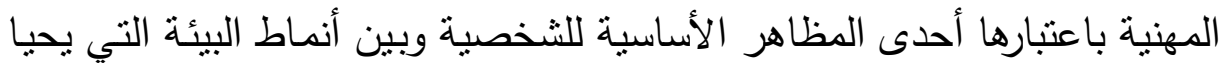

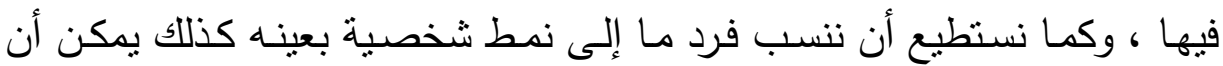

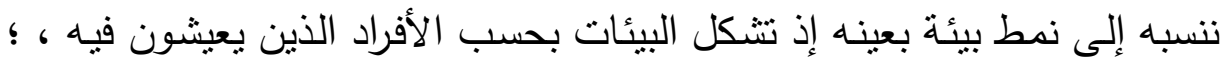

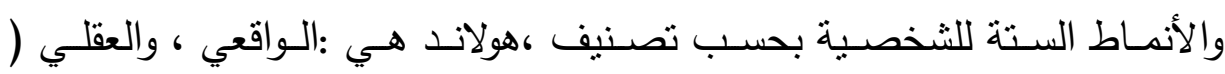
التحليلي)، والفنان ، والاجتماعي ، والمغامر ، والثقليدي ، وكل فرد ينتمي إلى التى

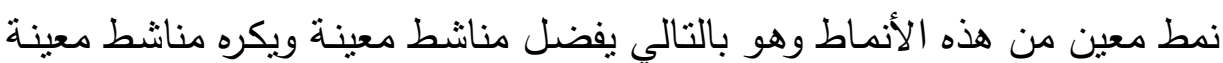


لا تتفق مـع نمط شخصيته ، وقد اعتمد الباحث على هذه الأنماط في تصميم

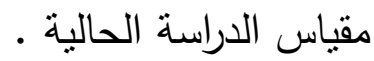

ويرى هولاند أن أي شخص يمكن أن يصنف تحت أحد تلاك الأنماط إما بواسطة ميوله التعليمية أو المهنية ، أو بواسطة الدرجات التي يحصل علئل عليها عند أخذه

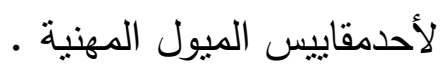
كما يرى أن لكل بيئة من البيئات يلتحق بها أفراد شخصياتهم شبيهة بشخصيات

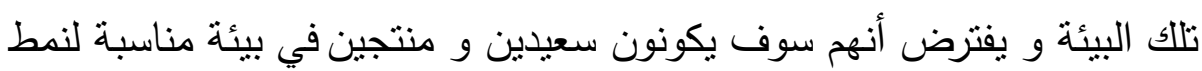
شخصياتهم و غير سعيدين و غير منتجين في بيئة لا تتاسب نمطشخصئسياتهم،

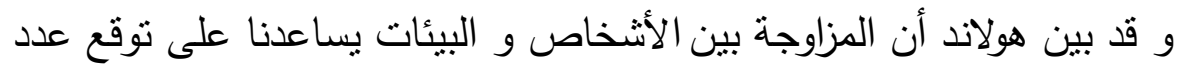

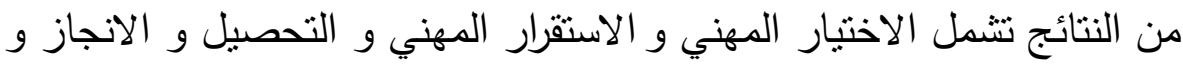

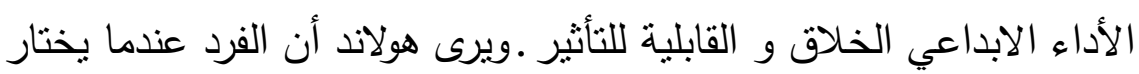

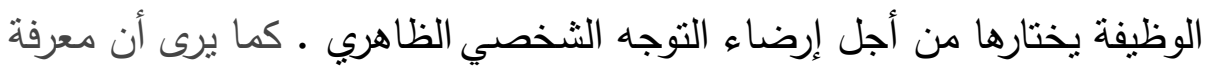

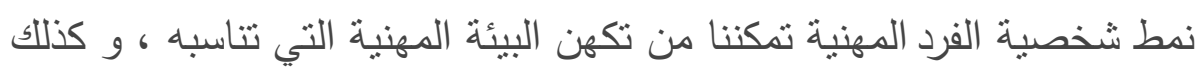
معرفة متطلبات مجال مهني معين يمكننا من تصوير شخصية الفرد الذي يسنطيع مهن أن يؤدي هذه المهنة بنجاح ـ كما أن درجة إندفاع الفرد نحو البيئات المهنية

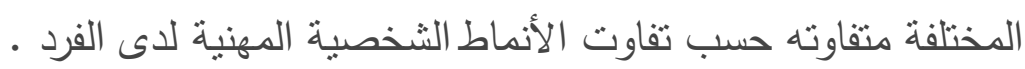
ع - نظرية آن رو، Anne Roe : وقد نشرت " آن رو " أراء النظرية في الفترة

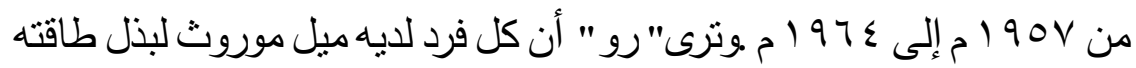
النفسية بطريقة ما،وهذا الميل بالاشتراك مع خبرات الطفولة يشكلان النمط الذي ينميه

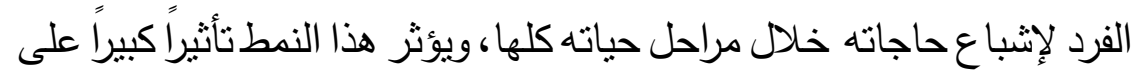

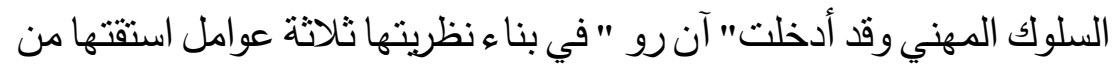
نظريات علم النفس وهي:مبدأ تصريف الطاقة النفسية وكذللك خبرات الطفولة، ، الحاجات النفسية، وقد اعتمدت في هذا الجانب على نظرية ماسلو للحاجات، تأثنير

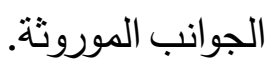


من خلال استعراض النظريات السابقة نجد أنها قد نتاولت الميول المهنية والاختيار المهني وأهم محدداته وبشكل عام فقد أكدت هذه النظريات على:

1

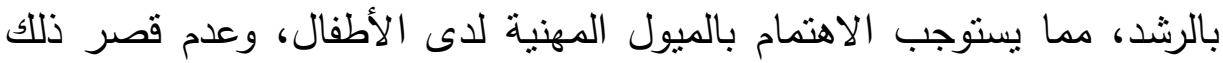
الاهتمام على الكبار ، ولذلك كان اهتمام هذه الدراسة بالتعرف على الميول المهنية

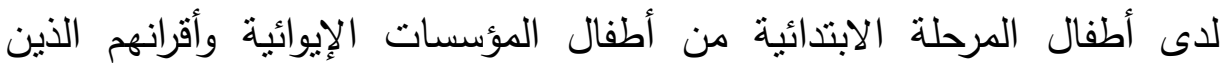
يعيشون مع أسر هم.

r - أن الميول المهنية تتأثز بعوامل خارجية كمطالب البيئة والضغوط الخارجية، وعوامل داخلية كالسمات المحددة للفرد منت القدرات والاستعدادت والميول.

r - أهمية خبرات الطفولة ومفهوم الذات، ونمط البيية، في تشكيل الميل المهني.

ع - الميل المهني يمكن قباسه من خلال قوائم الميول حيث بطلب من

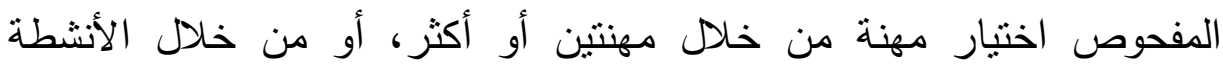
المصورة، وقد استفاد الباحث من الأطر النظرية للميول المهنية في بناء الأداة التي استخدمها في هذه الدراسة .

العوامل المؤثرة في الميول المهنية:

تؤثر كثثر من العوامل البيئية في ميول الفرد وتفضيلاته المهنية منل الطبقة

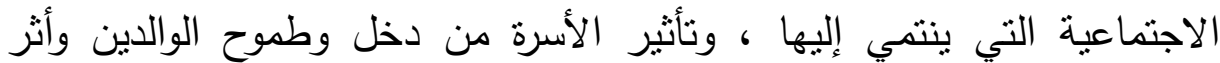
الأخوة والأخوات والبيئة والمجتمع المحلي. ، والمجتمع بدوره يؤثر في اختيارات 
الأفراد مهنهم، وذلك من خلال تصنيفه المهن من حيث قيمتها الاجتماعية، ولذا فالاتجاهات السلبية أو الإيجابية نحو المهن تتأثز بالتصنيف الاجتماعي. وإلاء

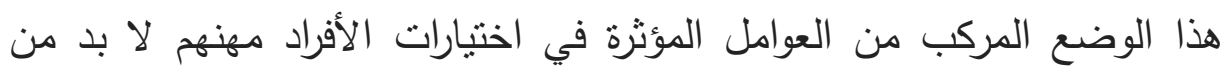

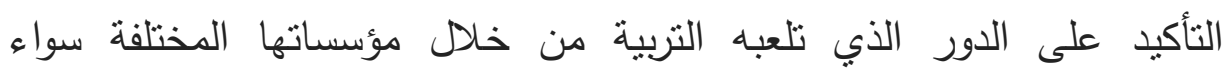

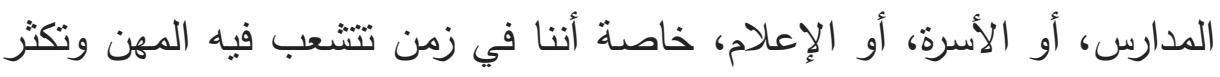

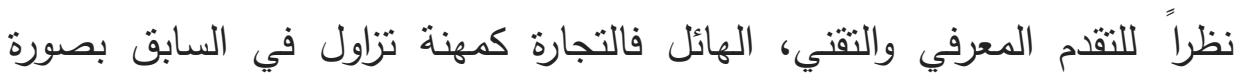

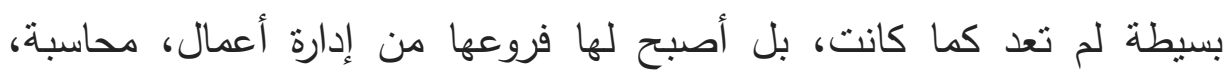

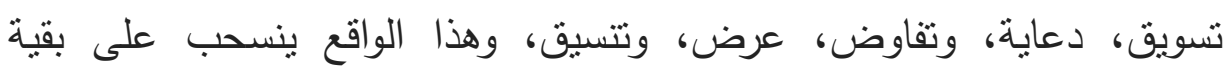

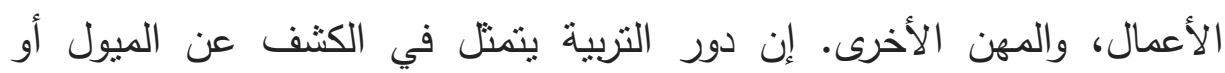
الرغبات والقدرات المتوافرة لدى الأفراد ومن ثم تتمية هذه الاستعدادات والارتقاء

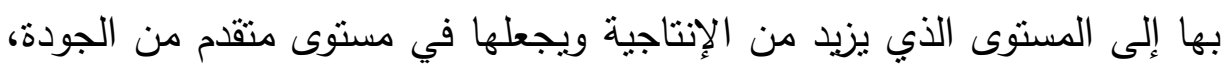

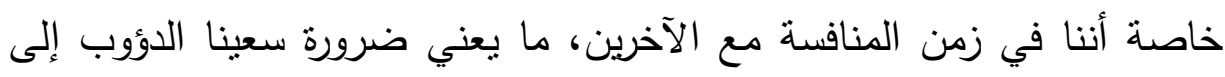

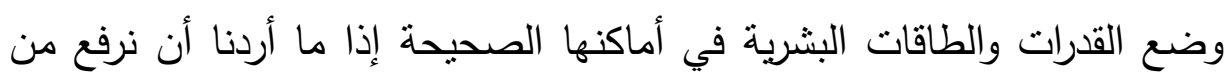

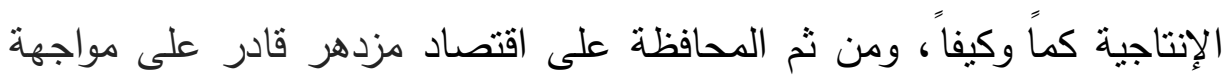

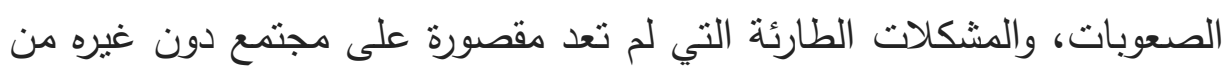
المجتمعات

ويمكن حصر أهم العوامل المؤثرة في الميول المهنية حسب نتائج الدراسات

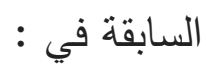
1 - العوامل الأسرية :أجمعت العديد من الدراسات على تأثير الأسرة في النمو

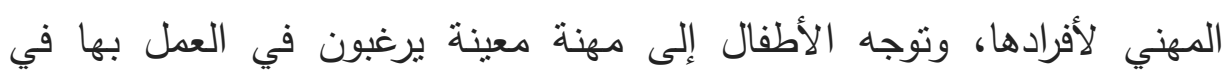

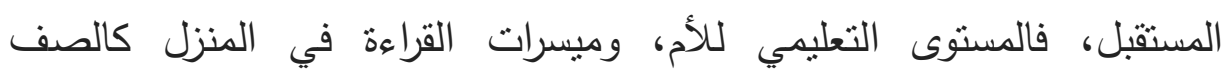
والمجلات والكتب فتشير دراسة أمل دكاك وأحمد الأصفر،99 199 ( ) إلى تأثير دور

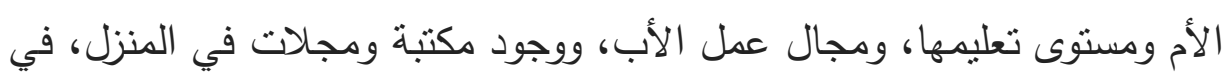
Baba. Mahila, اختيار الأطفال مهنة المستقبل، ودراسة بابا ك. ماهيليا، IVV 
التي توصلت إلى أنه يوجد فروق بين أبناء الأمهات المتعلمات، وبين أبناء غير المتعلمات في كل من التحصيل والميل المهني من حيث الميول التهيل القيادية والفنية

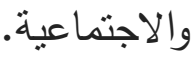

وأثنارت دراسة دخيل ذاكر العصيمي 1997 ، ، إلى أن أبرز العوامل

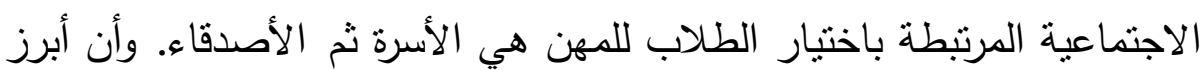

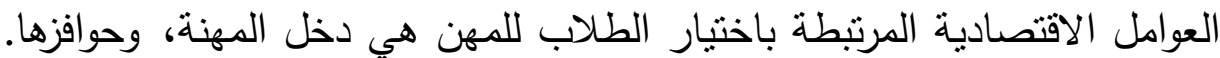

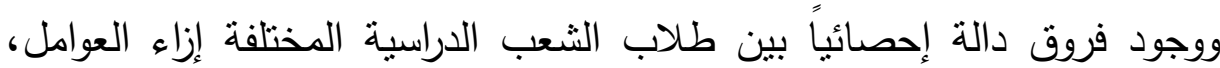
الاجتماعية ،والاقتصادية المتعلقة بالاختيار المهني. كما أن للتفاعل داخل الأسرة أثره في مساعدة أفرادها على اتخاذ التهاذ القرار

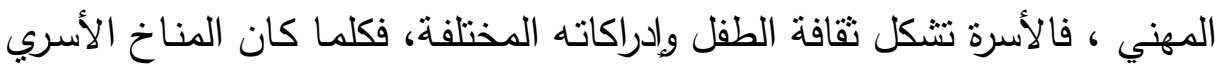

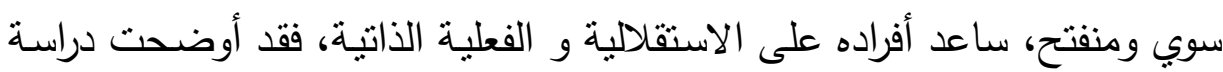
ويستون ،1996، ، أن هناك علاقة ارتباطيه ذات دلالة إحصائية بين أنماط، التفاعل الأسري المتمثل في التهيئة الإدراكية والثقافية وادراك أفراد العينة للفعالية الذاتية فيما

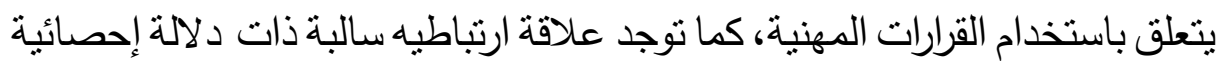

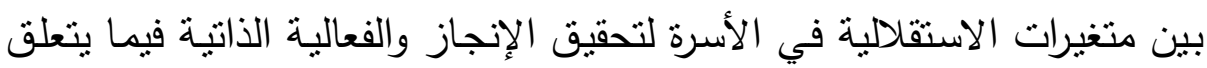

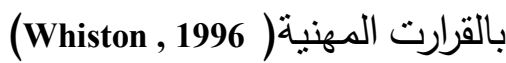
والطفل الذي يعيش في المؤسسة الإيوائية محروم من هذا الجو الأسري، الدتفاعل والمستقل، فهو يخضع لحياة تنظيمية ، روتينية، تنقتد الدفء الأسري،

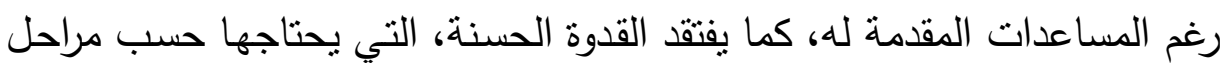
نموه المختلفة، مما يؤثر على استقلالينه، وميله للإعتمادية، وبالتالي على ميوله المهنية وقدرته على اتخاذ القرار المهني في المستقبل.

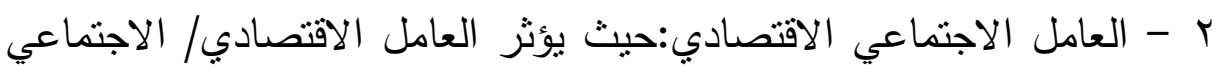

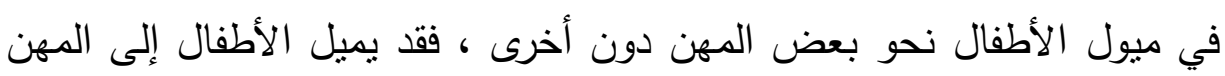

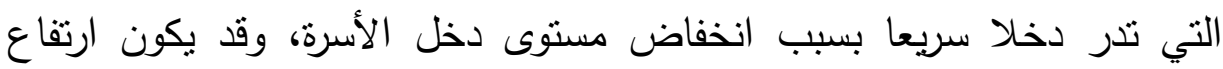


مستوى دخل الأسرة سببا في اختبار المهن التي تحتاج إلى كفاءة وتحقق مظهرا

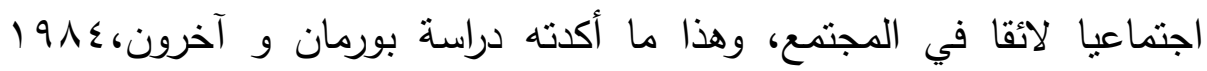
Borman et al,

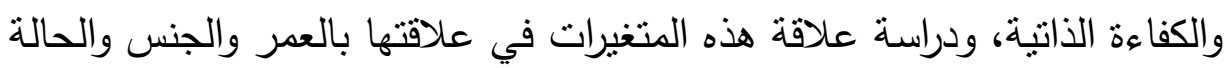

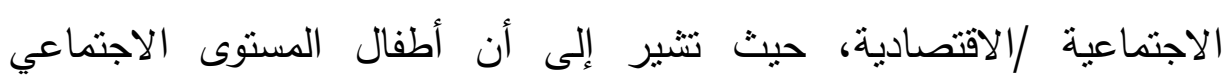

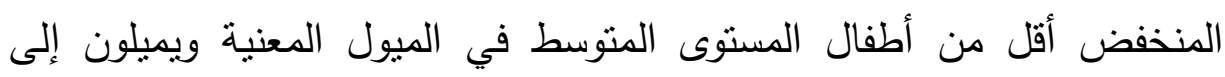

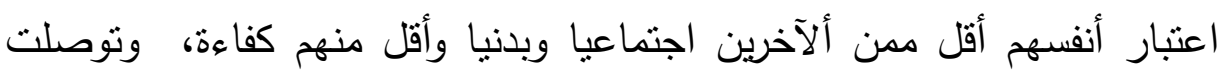

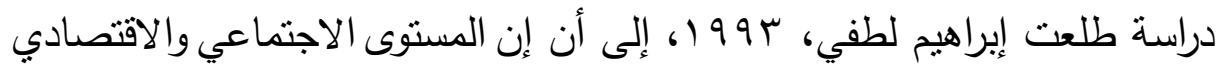

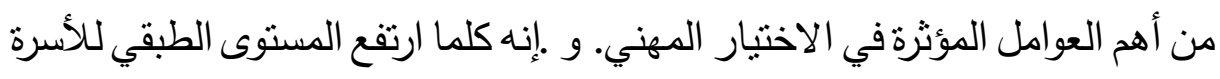
كلما زادت التطلعات لاختيار المهنة ذات المكانة العالية. r - السمات الثخصية: أكدت العديد من الدراسات على وجود علاقة ارتباطية موجبة بين الميول المهنية وبعض سمات الثخصية، كالكفاءة الاجتماعية، وتقدير

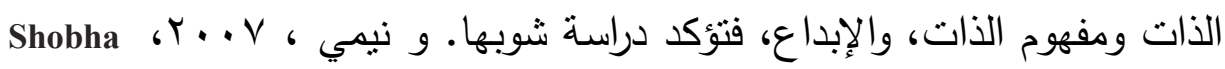
Nandwana and Nimmi Asawa الأكاديمي، والسمات الثخصية، كما توضح أن هناك علاقة قوية بين مفهوم

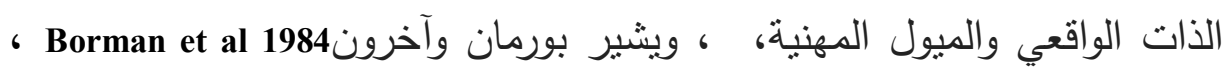

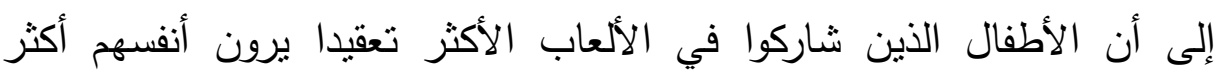

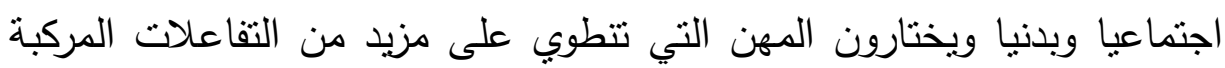

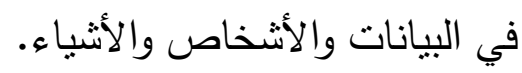

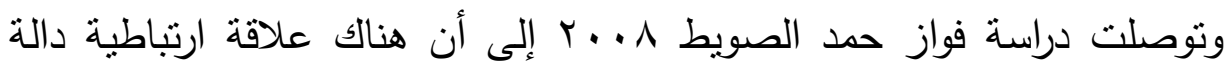
إحصائيا بين محددات الاختيار المهني والتوافق النفسي، وكذللك دراسة صالح

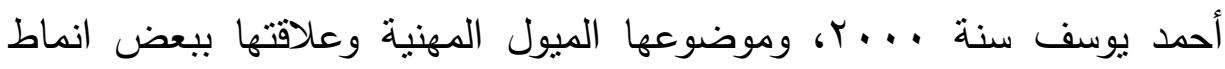
الثخصية كمدخل للتوجيه التربوي لطلاب المرحلة الثانوية بدولة الإمارات العربية المتحدة، وتوصلت الدراسة إلى أن هناك تفضيل من قبل الطلاب للبيئات المهنية 189 
جميعها ولكن بنسب متفاوتة حيث جاءت البيئة المهنية الاجتماعية في المقدمة ، وكانت البيئة الفنية أقل البيئات المهنية تفضيلا لدى الطلاب، وتوصلت دراسة صالح بن علي الغامدي، بو99 19، إلى أنه وتوجد علاقة سالبة دالة احصائيا بين الانبساط والبعد الواقعي والبعد التقليدي، والبحثي من مقياس التفضيل المهني،؛ وأبه

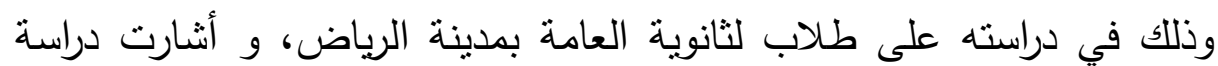

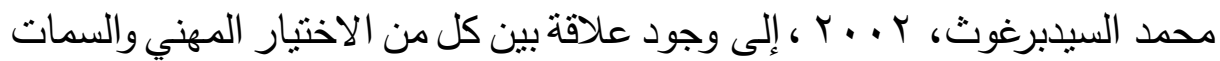
الثخصية والقدرات العقليةوبين العملية التوافقية الإيجابية. كما تؤكد نتائج دراسة رين برير ، Rene, Proyer,2006 على وجود علاقة ارتباطيه موجبة بين الذكاء والميول المهنية، فقد أكدت الدراسة وجود علاقة ارتباطية بين كل من الميول الواقعية والبحثية ( العقلية) وبين القدرات المكانية،

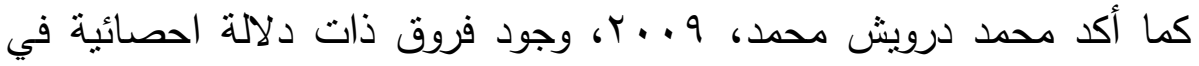
درجات الاختبار المهني تؤول لمتغير نمط الثخصية على خمس بيئات مهنية

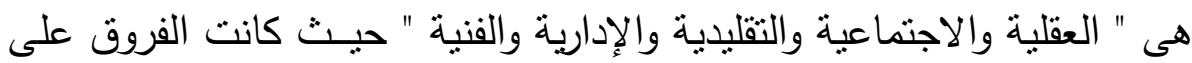
البيئة التقليدية في اتجاه النمط الحسي وعلى البيئة العقلية والاجتماعية والإدارية والفنية في اتجاه النمط الحدسي ـ كما أوضح أن هناك فروقاً ذات دلاهي لاتلة إحصائية في درجات الاختبار المهني تؤول لمتغير الجنس على أربع بيئات

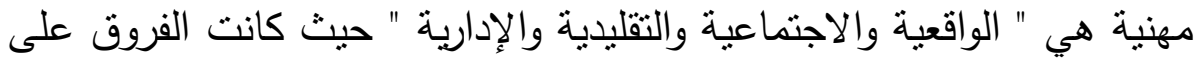
البيئتين الواقعية والإدارية في اتجاه الذكور ، وعلى البيئتين الاجتماعية

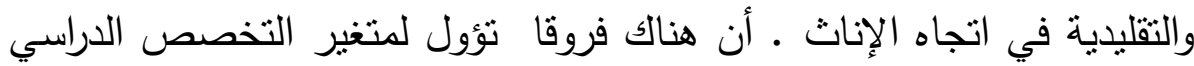
على ثلاث بيئات مهنية هي " الواقعية و العقلية والاجتماعية " . حيث كانت الفروق على البيئنين الواقعية و العقلية في اتجاه التخصص العلمي وعلى البيئة

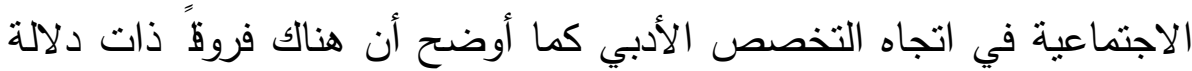

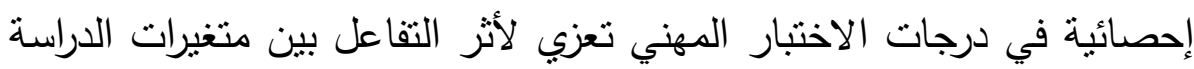

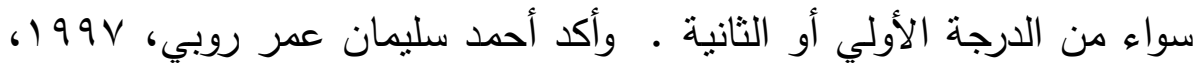


في دراسته التي تناولت الميول المهنية وعلاقتها بالتوجه نحو القوة الاجتماعية لاى طلاب وطالبات الكلية التكنولوجية بجامعة قطر ، وهدفت إلى التعرف على دلى دلى خصائص بنية الميول المهنية لدى عينة الدراسة وتحديد مدى التثابه أو لوابه

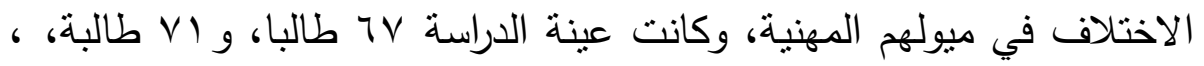
على أنه نوجد فروق في الميول المهنية بين الطلاب، وأن هناك علاقة بين الميول المهنية والتوجه نحو القوة الاجتماعية. وفي دراسة نصر الدين أمحمد

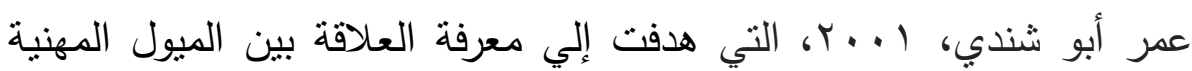
لطلبة مرحلة التعليم المتوسط في الجماهيرية العظمي ومستوي التحصيل

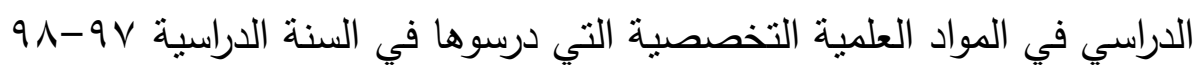
،أنشارت النتائج إلي عدم وجود علاقة ارتباط دالة إحصائيا بين الميول المهنية

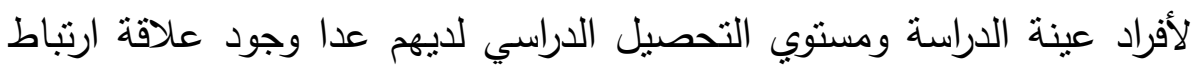

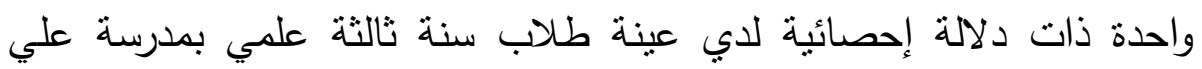

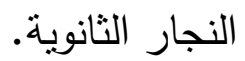

ومن خلال الدراسات السابق ذكرها ، يتضح أن الميل المهني ليس بمعزل

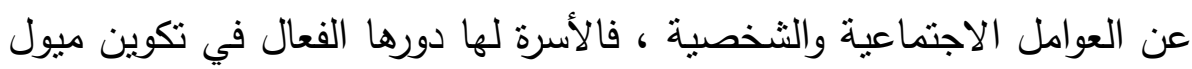
أبنائهم وتوجيهها ، وكذللك المستوى الاجتماعي الاقتصادي، نرى أن الأفراد

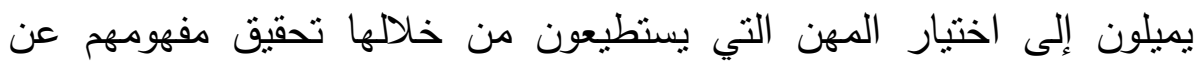

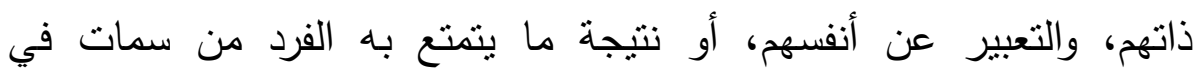

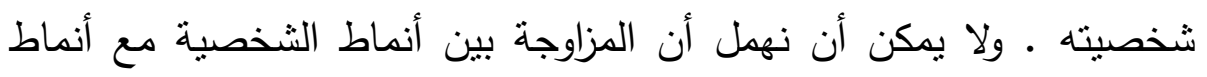

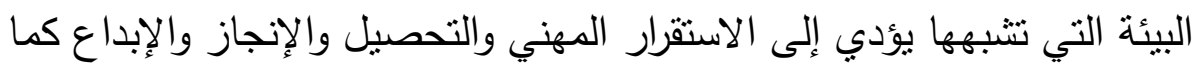
يؤكد هولاند في نظريته، وذللك يحتاج إلى مزيد من الاهتمام بالتربية المهنية في

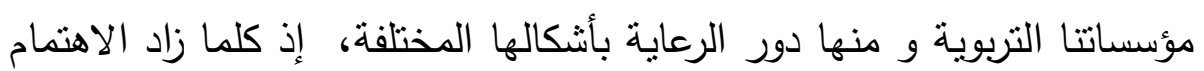

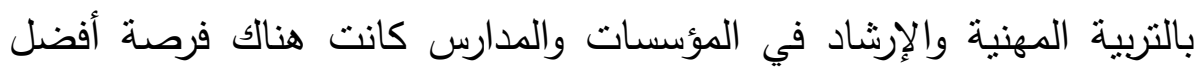
للأطفال لاختيار المهنة المناسب لسماتهم وإعدادهم التربوي والمهني، لأن 
للاختيار المهني أثر بعيد في شخصية الفرد في حياته الحاضرة والمقبلة. فهو قرار مصيري حاسم يحدد مستقبلة ويرسم لله معالم النجاح أو الفنشل، فالاختيار الصحيح يحيل الثباب إلى طاقات خلاقة ومنتجة. كما يحقق الاختيار المهني كثثرا من المنافع الاقتصادية والاجتماعية والنفسية. فمن الناحية الاقتصادية فإن اختيار الفرد للمهنة المناسبة له يؤدي إلى زيادة كفايته واحتمال ترقيته وزيادة

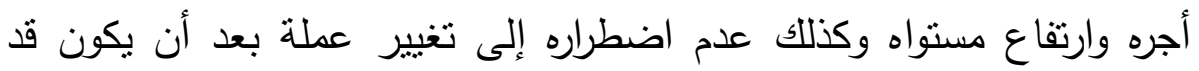
قضى فيه وقتاً طويلا ـ وبعد أن تكون المؤسسة قد أنفقت الكثير على تدريبه وتعليمه، وينعكس ذلك بالضرورة على جودة حياته وحياة أسرته، أن الاختيار الخاطئ قد يؤدي إلى سوء توافق الفرد مع عدم القدرة على مسايرة المجتمع بما

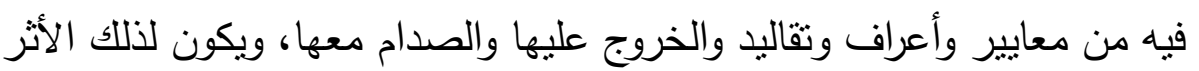

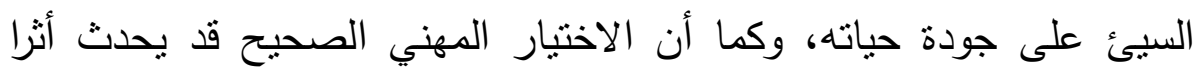
إيجابيا بحالة الفرد الصحية ويجعله فردا منوافقا يخلو من الصراعات الداخلية الثعورية واللاشعورية. ويتحلى بقدر من المرونة، ويستجيب للمؤثرات المهنية باستجابات ملائمة. ويتجه الكثير من الأفراد نحو مهن معينة، ويلتحقون بها نتيجة ميولهم نحوها، إن وضع المرء في المهنة التي تتاسبه من العوامل التي

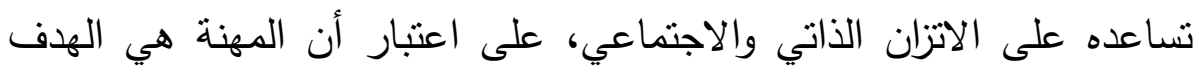
الذي يسعى إليه الفرد لكي يصبح عضوا مشاركا ومنتجا في المجتمع ، وقادرا على تحقيق السعادة له ولمن حوله ، وعلى العكس فعندما تكون المهنة غير مناسبة فإن سعادته لا تتحقق وبالتالي سيترتب على ذلى كلى انخفاض إنتاجيته

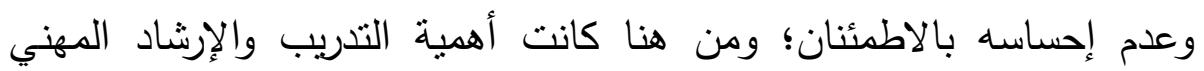
المدرسي لأطفالنا ليتحقق لهم مسنقبل مهني وحياتي أفضل، وأطفال المؤسسات ومنات الإيوائية أكثر الفئات حاجة إلى الاهنمام بجودة حياتهم ، ومساعدتهم على لهانى الاندماج في المجتمع والمشاركة الإيجابية في نشاطاته.

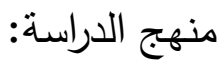


استخدمت الدراسة المنهج الوصفي- الارتباطي المقارن- حيث هدفت

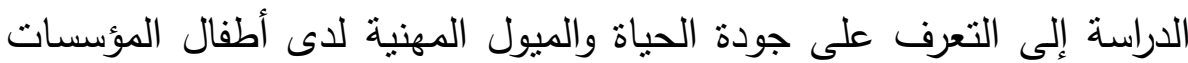
وأقرانهم الذين يعيشون مع أسرهم. عينة الدراسة :

تكونت عينة الدراسة من •^ طفلا وطفلة، ·ـمن أطفال المؤسسات

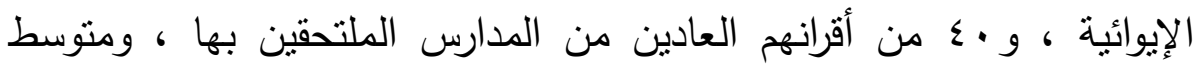

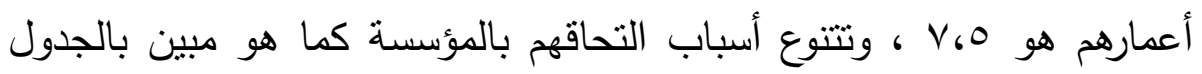

رقم (1)

جدول رقم (1) يبين خصائص العينة

\begin{tabular}{|c|c|c|c|}
\hline المجموع & أطفال يعيشون مع & أطفال المؤسسات & النوع \\
\hline & - & v & يتيم \\
\hline & - & 17 & مجهول \\
\hline & - & $1 \varepsilon$ & تفكك أسري \\
\hline & - & r & حالة اقتصادية \\
\hline$\Lambda$. & $\varepsilon$. & $\varepsilon$. & المجموع \\
\hline
\end{tabular}

$$
\text { أدوات الدراسة: }
$$

مقياس جودة الحياة: إعداد الباحث.

$$
\text { وصف المقياس: }
$$

يتكون المقياس من ثلاثة جوانب رئيسة كما وصفها كريج جاكسون وهي الكينونـة

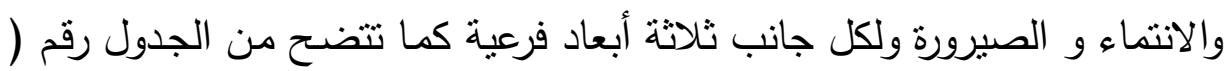

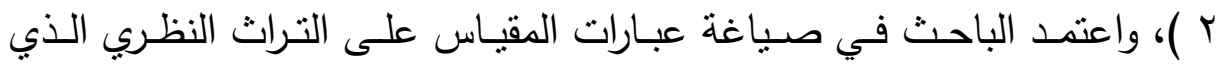
IN 
تتاول جودة الحياة، والمقاييس المختلفة لجودة الحياة، منل مقياس منظمة الصحة العالمية ه . . ب، ومقياس جودة الحياة لسامي هاشم I . . r، ومقياس جودة الحياة

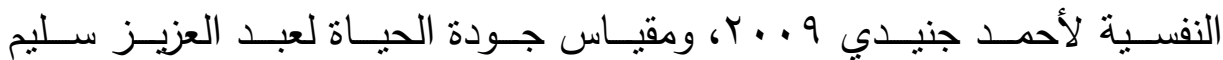

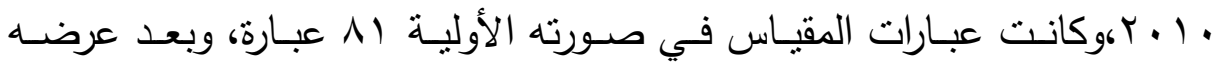
للتحكيم وصلت عبارات المقياس في صورته النهائية ؟0 عبارة؛ كل مجال تمثله 1 1 عبارة، وكل بعد تمثله 7 عبارات، والجدول رقم ( r ) يبين مجالات المقياس وأبعاده، وتعريف كل بعد، وقام الباحث بإعداد صـورتين من المقيـاس، أحدهما لأطفال المؤسسات، والأخرى للأطفال الذين يعيشون مع أسرهم. ( ملحق رقم 1 ) جدول رقم (Y) مجالات وأبعاد جودة الحياة.

\begin{tabular}{|c|c|c|}
\hline التعريف & الأبعاد & المجال \\
\hline 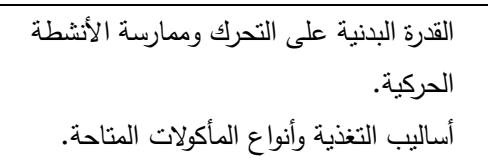 & $\begin{array}{r}\text { Physical الوجود البدني } \\
\text { Being }\end{array}$ & \multirow[t]{3}{*}{$\begin{array}{r}\text { Being } \\
\text { Bينونة(الوجود) }\end{array}$} \\
\hline 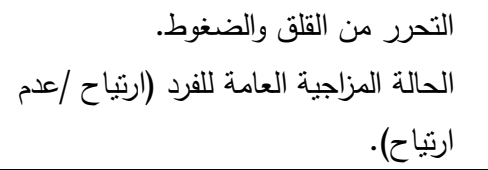 & $\begin{array}{c}\text { Psychological Being } \\
\text { Psود النفسي }\end{array}$ & \\
\hline وأفكار الفرد الذانية عن الصواب المستقبل (الاستبشار). & $\begin{array}{r}\text { Spiritual الوجود الروحي } \\
\text { Being }\end{array}$ & \\
\hline نطاق الجيرة التي تحتوي الفرد. الثقة التي أعيش فيها. & 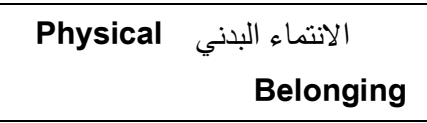 & \multirow{3}{*}{$\begin{array}{r}\text { الانتماء } \\
\text { Belonging }\end{array}$} \\
\hline القرب من أعضاء الأسرة التي أعيش معها. & $\begin{array}{r}\text { Social الانتماء الاجتماعي } \\
\text { Belonging }\end{array}$ & \\
\hline 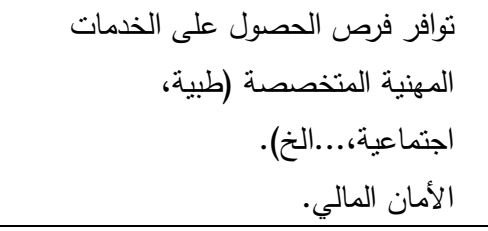 & $\begin{array}{c}\text { الانتماء المجتمعي } \\
\text { Community Belonging }\end{array}$ & \\
\hline العمل في وظيفة أو الذهاب إلى المدرسة. & $\begin{array}{r}\text { Practical الصيرورة العملية } \\
\text { Becoming }\end{array}$ & الصيرورة \\
\hline
\end{tabular}




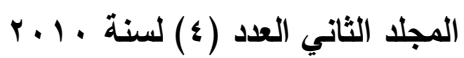
مجلة كلية التربية بدمنهور · جامعة الاسكندرية

\begin{tabular}{|c|c|c|}
\hline 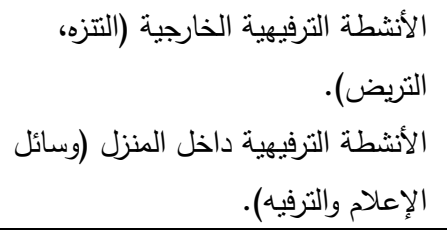 & $\begin{array}{r}\text { Leisure الصيرورة التزفيهية } \\
\text { Becoming }\end{array}$ & Becoming \\
\hline الحسين الكفاءة البدنية والنفسية. & $\begin{array}{r}\text { Groth الصيرورة الارتقائية } \\
\text { Becoming }\end{array}$ & \\
\hline
\end{tabular}

Craig Jackson, 2010,10-13

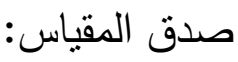

صـاغ الباحث أبعاد المقياس في شكل عبارات يمكن قياسـها ، وصلت إلى عبارة ثم تم عرضـها على مجموعة من المحكمين من أسـاتذة الجامعة المهتمين

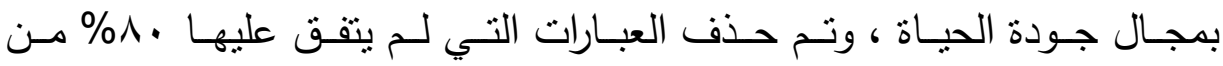
المحكمين وتعديل بعض العبارات ليصبح المقياس في صورته النهائية ؛ عبارة. ثبات المقياس:

قام الباحث بحساب ثبات المقياس باستخدام معامل ثبات ألفا وكانت النتائج

كما هو مبين بالجدول رقم(ب)

جدول رقم (r ) يبن معامل ثبات مقياس أبعاد جودة الحياة

\begin{tabular}{|c|c|c|c|c|c|c|c|c|c|c|}
\hline الارجة الكلة & الارتقائيةورة & الترفيرية & الصعيرورة & المجتمعي الاتتماء & الاجتماعي الانتماء & الانتماء & الروجي الرجي & النفسي & البدجود & البعد \\
\hline$\cdot, \wedge \wedge$ & $\cdot, \wedge r$ & $\cdot, \wedge 0$ & $\cdot, \wedge q$ & ^צ, • & $\cdot, \vee^{\prime}$ & $\cdot, \wedge 1$ & $\cdot, \wedge \leq$ & $\cdot, \mathrm{VA}$ & $\cdot, \mathrm{VT}$ & الثبات \\
\hline
\end{tabular}

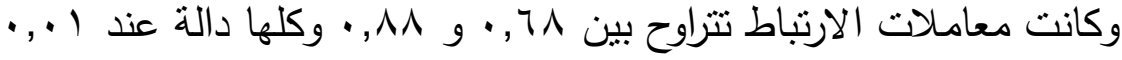

مدا يشير إلى ثبات المقياس المعد. الاتساق الداخلي للمقياس:

حيث طبق المقياس على · r من أطفال المؤسسات الإيوائية و • r من الأطفال الذين يعيشون مع أسرهم تم اختارهم بطربقة عشوائية، وتم حساب معامل الارتباط 
بين أبعاد المقياس بعضها ببعض وبين الدرجة الكلية كانت النتيجة كما هو مبين

$$
\text { في الجدول رقم ( ) }
$$

جدول رقم (ع ) يبين ارتباط أبعاد المقياس يبعضها وبالدرجة الكلية

\begin{tabular}{|c|c|c|c|c|c|c|c|c|c|c|c|}
\hline الارجة & \multicolumn{3}{|c|}{ الصيرورة } & \multicolumn{3}{|c|}{ الانتماء } & \multicolumn{3}{|c|}{ الكينونة } & \multicolumn{2}{|c|}{ المجال } \\
\hline & الارتقائية & الترفيهية & العملية & المجتمعي & الاجتماعي & المكاني & الروحية & النفسية & البدنية & & \\
\hline$\cdot, v r$ &., 09 &., 79 & $\cdot, \mathrm{vV}$ & . & $\cdot, v \varepsilon$ & $\cdot, \wedge 0$ & צ & $\cdot, v r$ & & البدنية & \\
\hline$\cdot, \wedge \varepsilon$ & $\cdot$, vo & $\cdot, v \leq$ & $\cdot, \wedge$. & • & $\cdot, v_{0}$ & $\cdot, \wedge 1$ & $\cdot, \vee \wedge$ & & & النفسية & 星 \\
\hline . & $\cdot, 79$ & $\cdot, \vee \wedge$ & 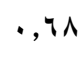 & $\cdot, \wedge 4$ & $\cdot, v r$ & סו, • & & & & الروحية & \\
\hline$\cdot, \vee \vee$ & $\cdot, V \leqslant$ & צ & $\cdot, \mathrm{VI}^{\prime}$ & $\cdot, \infty$ & ד & & & & & المكاني & \\
\hline$\cdot, \vee \wedge$ & $\cdot, \wedge 0$ & $\cdot, \wedge 1$ & $\cdot, 79$ & $\cdot, \wedge \bullet$ & & & & & & الاجتماعي & 诗 \\
\hline$\cdot, \wedge \vee$ & $\cdot, V \leqslant$ & צד, & $\cdot, \wedge \vee$ & & & & & & & المجتمعي & \\
\hline$\cdot, \mathrm{VV}$ & $\cdot, \uparrow$ & $\cdot, 0 \mathrm{~V}$ & & & & & & & & العملية & 3 \\
\hline
\end{tabular}




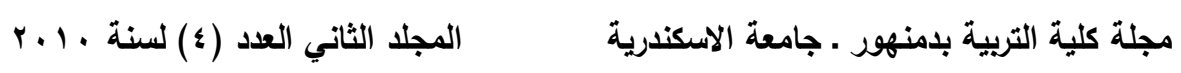

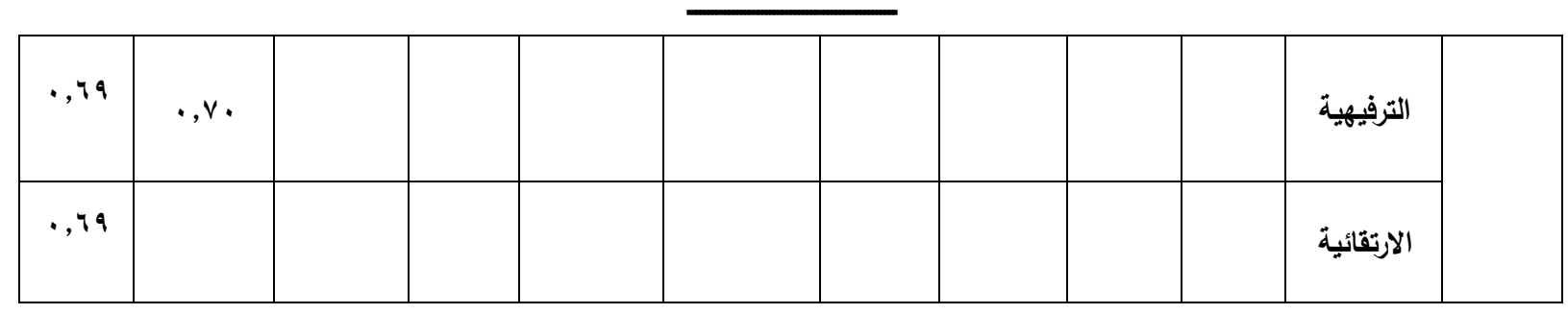

ويتضح من الجدول السابق أن معاملات الارتباط بين أبعاد المقياس بعضها البعض عالبة وذات دلالة إحصائية عند 1 , , حيث نتراوح هذه المعامالت بين

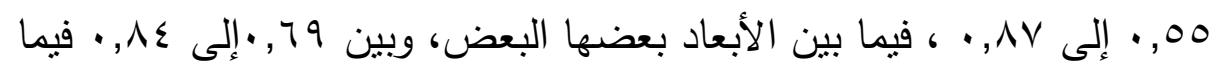
بين الأبعاد والدرجة الكلية للمقياس، وتم حساب معامل الارتباط بين مجلات المقياس المختلفة في الجدول رقم (0 ) فكانت معاملات ارتباط مرتفعة تتراوح بين

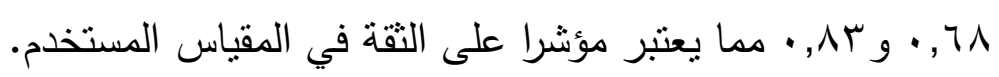
جدول رقم ( 0 ) يبين الارتباط يبن درجات مجالات مقياس جودة الحياة بعضها ببعض وبين الدرجة الكلية

\begin{tabular}{|c|c|c|c|c|}
\hline الكلية & الصيرورة & الانتماء & الكينونة & المجال \\
\hline$\cdot, v_{1}$ & •, & $\cdot, \mathrm{V} \cdot$ & & الكينونة \\
\hline$\cdot, \vee \wedge$ & $\cdot, 79$ & & & الانتماء \\
\hline$\cdot, \uparrow \wedge$ & & & & الصيرورة \\
\hline
\end{tabular}

1 - مقياس الميول المهنية: إعداد الباحث.

اطلع الباحث على العديد من مقاييس الميول المهنية؛ المصورة منها

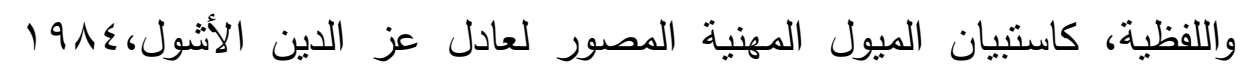




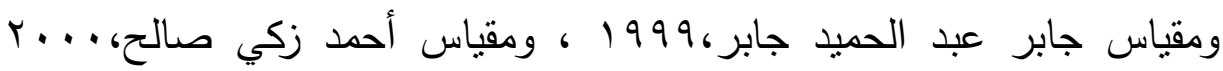
ووجد أن معظمها أعد للأعمار المتقدمة أو للمعوقين عقليا،مما يجعل استخدامها مع الأعمار الصغيرة غير مجد في الدراسة الحالية، كما أن معظمها يتتاول عبارات كثيرة تربو عن المائنين في بعض المقاييس أو . .0 عبارة في مقاييس

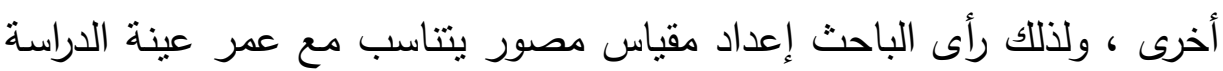

وخصائصها.

$$
\text { وصف المقياس: }
$$

يتكون المقياس •r نشاطا ، تمنل ستة من الميول المنية المختلفة حب

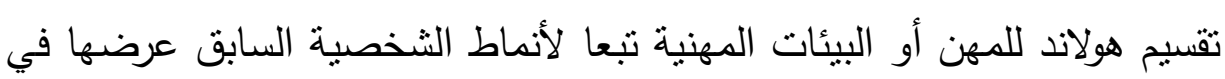
الإطار النظري ، كل ميل تمثله خمسة أنشطة، تعرض في شكل خمس بطاقات كل بطاقة تتضمن ست صور ، تمثل كل صورة نشاطا معينا، يمنل نمطا من ألأنماط البيئية المهنية عند هولاند ويطلب من المفحوص أن يختار نشاطا واحدا

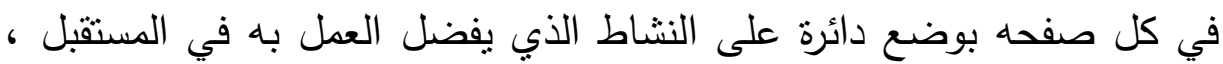
والمقياس من صورتين صورة للذكور وصورة للإناث.ملحق رقم (r)

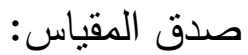

1 - صدق المحكمين:عرض المقياس في صورة الأولية على مجموعة من المحكمين، وكان يتكون من بك صورة تعبر عن الأنشطة المهنية المختلفة، وتم

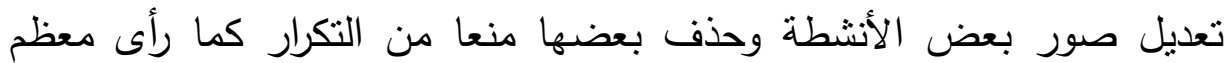

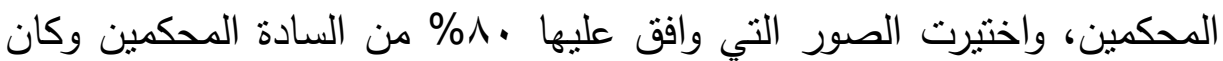
عددهم عشرة من السادة أساتذة الجامعات والإخصائين النفسانيين العاملين في مجال المؤسسات الإيوائية، ليتكون المقياس في صورته النهائية من •ب صورة تمنل الأنشطة المهنية المختلفة( ملحق رقم r ) r - الصدق من خلال حساب استقلالية الميول المستخدمة في المقياس: 


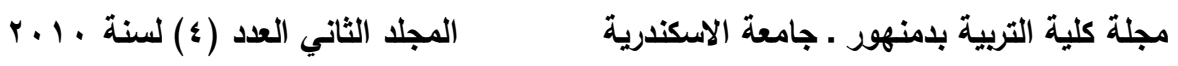

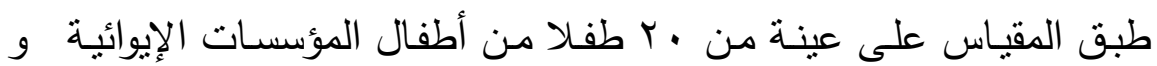

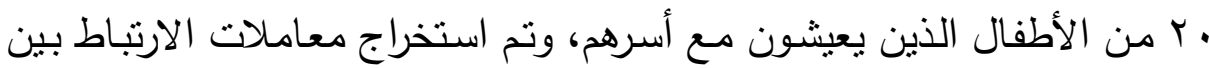

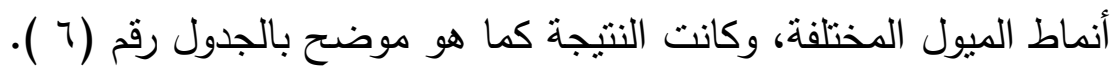

جدول رقم (7 ) يين الارتباط بين أنماط الميول المختلفة في المقياس

\begin{tabular}{|c|c|c|c|c|c|c|}
\hline التقليدي & المغامر & الاجتماعي & الفني & التحليلي & الواقعي & \\
\hline$\cdot, r O-$ & . & $\cdot, r Y-$ & $\cdot, \cdot \wedge-$ & $\cdot, r \cdot-$ & 1 & الواقعي \\
\hline$\cdot, Y_{1}-$ & $\cdot, r V-$ & $\cdot, r 1-$ & $\cdot, 19-$ & 1 & & التحليلي \\
\hline$\cdot, \mid \vee-$ & $\cdot, r \leq-$ & $\cdot, 14$ & 1 & & & الفني \\
\hline$\cdot, \cdot V-$ & .,$r_{-}$ & 1 & & & & الاجتماعي \\
\hline$\cdot, .9-$ & 1 & & & & & المغامر \\
\hline 1 & & & & & & التقليدي \\
\hline
\end{tabular}

يتضح من الجدول السابق أن معاملات الارتباط بين بين الميول المختلفة في

المقياس ذات دلالة سلبية ومنخفضة، مما يشير إلى استقلالية كل ميل عن الميول الأخرى، وبالتالي التأكيد على صدق دانه المقياس المستخدم.

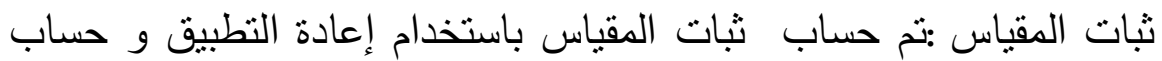

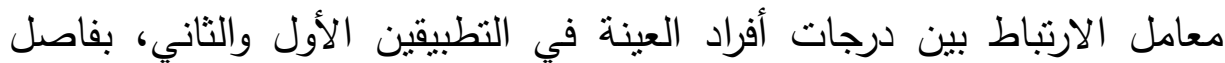

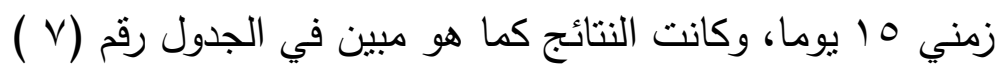

جدول رقم ( V ) بيين الارتباط بين مرتي تطبيق اختبار الميول المهنية.

\begin{tabular}{|c|c|c|c|c|c|}
\hline الدلالة & الارتباط & \multicolumn{2}{|c|}{ إعادة التطبيق } & \multicolumn{2}{|c|}{ التطبيق الأول } \\
\hline \multirow[t]{2}{*}{$\cdot, \cdot 1$} & $\cdot, V r$ & انحراف معياري & متوسط & انحراف معياري & متوسط \\
\hline & & $\cdot, r$ & $\varepsilon, 9$ & $\cdot, r \Lambda$ & $\varepsilon, \wedge r$ \\
\hline
\end{tabular}


وكان معامل الارتباط بين التطبيقين هو 0,72، وهو ارتباط دال احصائيا عند

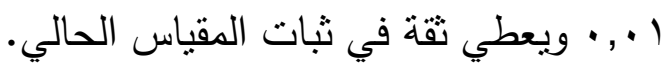

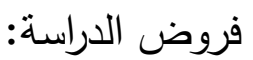

1 - توجد فروق ذات دلالة إحصائية بين منوسط درجات أطفال المؤسسات

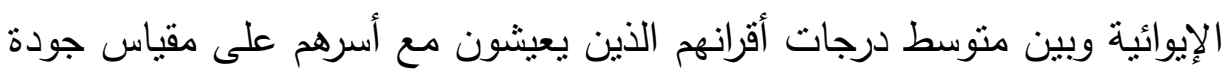
الحياة لصالح الأطفال الذين يعيشون مع أسرهم. r - نوجد فروق ذات دلالة إحصائية بين منوسطات درجات مجموعات الات دات أطفال المؤسسات الإيوائية حسب ميولهم المهنية.( الواقعية - التحليلية - الفنية الاجتماعية - المغامرة - التقليدية ) على مقياس جودة الحياة. r - توجد فروق ذات دلالة إحصائية بين متوسطات درجات مجموعات الأطفال الذين يعيشون مع أسرهم حسب ميولهم المهنية.( الواقعية - التحليلية الفنية - الاجتماعية - المغامرة - التقليدية ) على مقياس جودة الحياة. ع - لاتوجد فروق ذات دلالة احصائية بين الذكور والأناث على مقياس

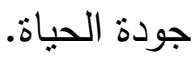
ه ـ يختلف ترتيب الميول المهنية لدى أطفال المؤسسات عنه لاى الأطفال

$$
\text { الذين يعيشون مع أسرهم. }
$$

بالنسبة للفرض الأول الذي نصه " توجد فروق ذات دلالة إحصائية بين منوسط درجات أطفال المؤسسات الإيوائية وبين منوسط درجات أقرانهم الذين يعيشون مع أسرهم على مقياس جودة الحياة لصالح الأطفال الذين يعيشون. كانت النتائج كما هو مبين بالجدول رقم ( 1 ) الجدول رقم ( ^ ) يبين الفروق بين أطفال المؤسسات الإيوائية و الأطفال الذين يعيشون مع أسرهم على مقياس جودة الحياة

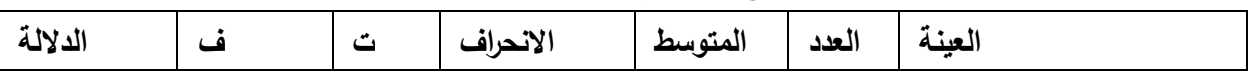




\begin{tabular}{|c|c|c|c|c|c|c|}
\hline & & & المعياري & & & \\
\hline \multirow[t]{2}{*}{. .1} & \multirow[t]{2}{*}{$11,4 \leq$} & \multirow[t]{2}{*}{11,1} & r, & rr & $\varepsilon$. & أطفال المؤسسات الإيوائية \\
\hline & & & O,r & \& & $\varepsilon$. & أطفال يعيشون مع أسرهم \\
\hline
\end{tabular}

بحساب الفروق باستخدام اختبار T test تشير النتائج إلى وجود فروق ذات

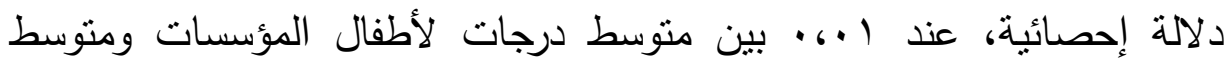
درجات الأطفال الذين يعيشون مع أسرهم على مقياس جودة الحياة لصالح

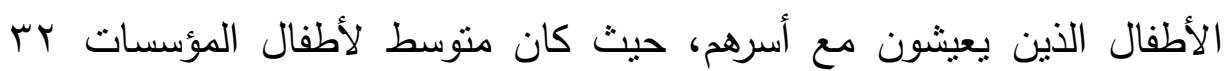

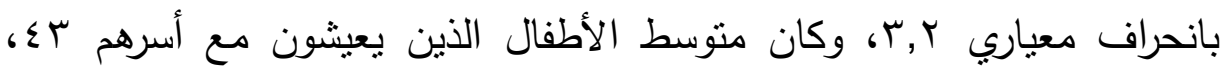

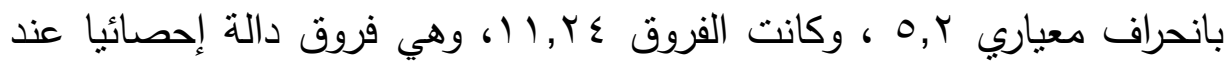

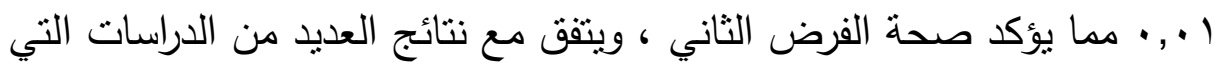

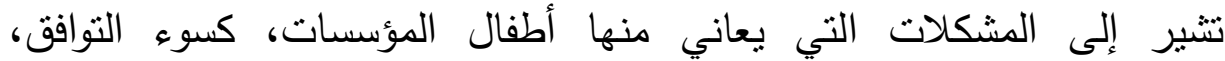

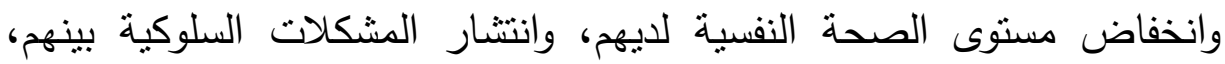
كالعدوان، والانسحاب، وعدم القدرة على التمتع بالحياة، والإحساس بالدونية،

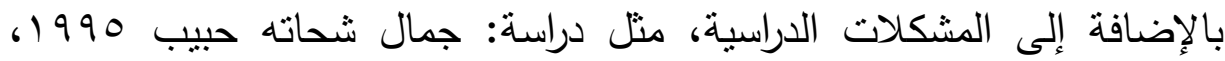

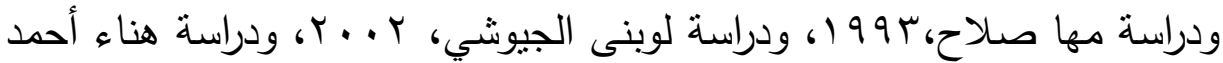

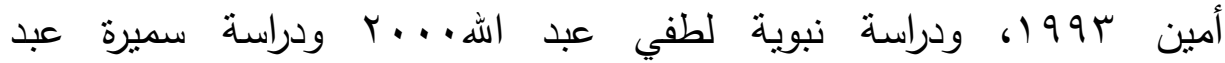

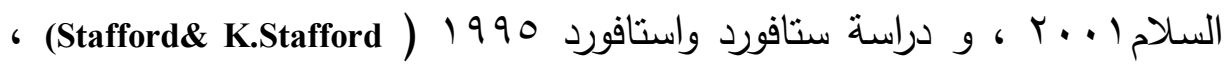
مما يؤثر على إدراكهم لحياتهم، والرضا عنها، حيث يعيشون رغم الخدمات المقدمة حياة بعيدة عن جو الأسرة الطبيعي، فيحرم من إثباع الكثير من حاجاته

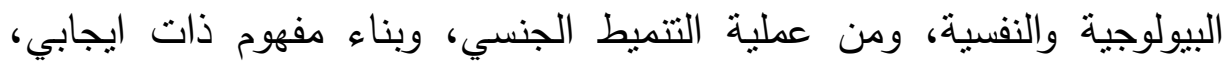
وفقدانه الأمن الذاتي والاجتماعي، ويؤدي ذللك إلى انخفاض مستوى جودة الحياة لديهم عن أقرانهم في البيئة المحيطة بالمدرسة. وبالنسبة للفرض الثاني والذي ينص على أنه: 
"توجد فروق ذات دلالة إحصائية بين متوسط درجات مجموعات أطفال

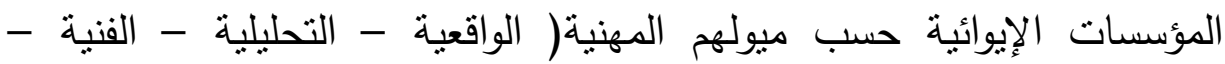

الاجتماعية - المغامرة - التقليدية ) على مقياس جودة الحياة"

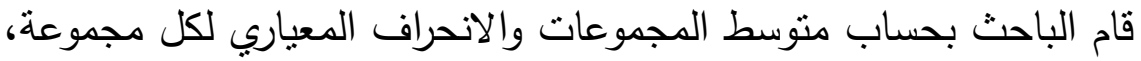
ثم تم حساب الفرق بين منوسط المجوعات الست و كانت النتائج كما في الجدول

$$
\text { رقم(9 ) والجدول رقم (·) }
$$

الجدول رقم(9) يبين المتوسطات والانحراف المعياري للميول المختلفة لأطفال المؤسسات الإيوائية

\begin{tabular}{|c|c|c|c|}
\hline العدد العد & الانحراف المعياري & المتوسط & الميل \\
\hline 10 & $r, \varepsilon$ & rq,qrr & الواقعي \\
\hline$r$ & 1 & $r q, \ldots$ & التحليلي \\
\hline$r$ & 1,0 & Vדז4,ו ו" & القنى \\
\hline$\wedge$ & $r, \varepsilon$ & rY,AvO. & الاجتماعي \\
\hline & $\varepsilon, Y$ & $r \varepsilon, \ldots$ & المغامر \\
\hline 9 & $1, \wedge$ & rrr,rrr & التقليدي \\
\hline$\varepsilon$ & 4,19 & rr,.vo. & المجموع \\
\hline
\end{tabular}

الجدول رقم(• ( ) يبين الفروق بين المجموعات بالنسبة للميول ودلالتها 


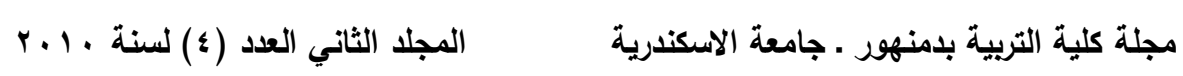

\begin{tabular}{|c|c|c|c|c|c|}
\hline الدلالة & قيمة (ف) & المتوسط & درجة الحرية & مجموع المربعات & \\
\hline \multirow[t]{3}{*}{$\cdot, \cdot 1$} & $r, \Lambda \cdot r$ & 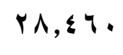 & 0 & $1 \leqslant r, r \ldots$ & بين المجموعات \\
\hline & & $\vee, \leqslant \wedge \diamond$ & r & $r 0 \leq, \leq V 0$ & $\begin{array}{l}\text { المجموعات داخل } \\
\text { داخل }\end{array}$ \\
\hline & & & $r q$ & 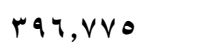 & المجموع \\
\hline
\end{tabular}

حيث نشير النتائج إلى أن هناك فروقا ذات دلالة إحصائية بين المجموعات المختلفة حسب مبولهم على مقياس جودة الحياة، وهي فروق دالة احصـايا عند

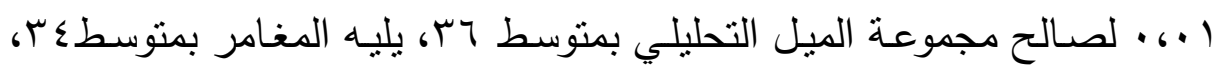

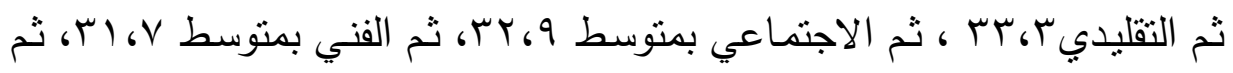
الواقعي بمتوسط 9،9 9، فالأطفال ذوي الميول التحليلية لديهم إدراك أفضل لجودة حياتهم ، يليهم المغامرون ثم أصـاب الميول التقليدية، وأصـحاب الميول الفنيـة ، والاجتماعيـة ، واخيرا الواقعيـة، الذين يميلون للمهن الواقعية التي ترتبط بالمكسب السربع، أو تتسـم بالحربـة، مثنل الميكانيكي ، والنقاش، والمـزارع، واللحـام، وغيرهـا من المهن اليدويـة التي ترتبط ببيئة المؤسسـة وطبيعتها، والتدريب المهني المقدم للأطفـال في هذه المؤسسـات، مدـا يسـتدعي الاهتمـام بالتوجيـه المهني المقترن بتحسين أوضـاع هؤلاء الأطفال وتحسين توافقهم الذاتي و الاجتمـاعي وصستهم

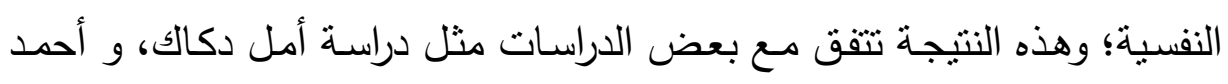

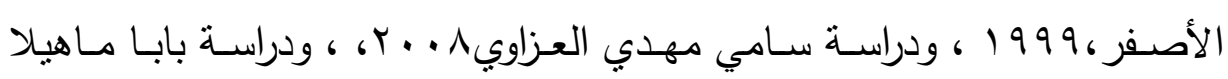

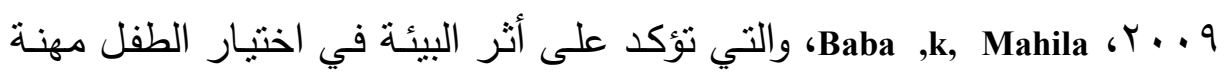
المستقبل، ودور الأسرة في ذلك. 
وبالنسبة للفرض الثالث والذي نصه:

"توجد فروق ذات دلالة إحصائية بين متوسطات درجات مجموعات الأطفال

الذين يعيشون مع أسرهم حسب ميولهم المهنية.( الواقعية - التحليلية - الفنية -

الاجتماعية - المغامرة - التقليدية ) على مقياس جودة الحياة."

فإنه بحساب الفروق باستخدام اختبار T test للعينات المستقلة، كانت النتيجة

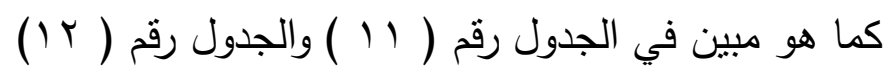

الجدول رقم(1 (1) يبين المتوسطات والانحراف المعياري لميول الأطفال الذين

\begin{tabular}{|c|c|c|c|}
\hline \multicolumn{4}{|c|}{ يعيشون مع أسرهم } \\
\hline العدد & الانحراف المعياري & المتوسط & الميل \\
\hline 1. & $r, 0 \leqslant$ & $\varepsilon \varphi, q$ & تحليلي \\
\hline$\wedge$ & $1, \leqslant 9$ & rq, ro & تقليدي \\
\hline$v$ & r, r & $m 4, r q$ & واقعي \\
\hline 7 & r,14 & V & الاجتماعي \\
\hline - & $r, r$. & $\leqslant v, r$ & فني \\
\hline ؛ & $r, 1$. & $\leqslant 9, r_{0}$ & مغامر \\
\hline$\varepsilon$. & $0, \Lambda$ & $\approx 1,1$. & المجموع \\
\hline
\end{tabular}

الجدول رقم(r ا ) يبين الفروق بين المجموعات بالنسبة للميول ودلالتها

للأطفال الذين بعيشون مع أسرهم 


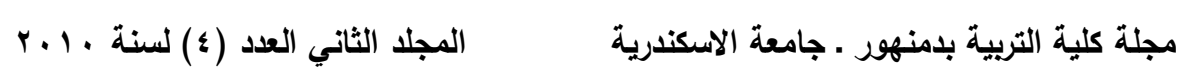

\begin{tabular}{|c|c|c|c|c|c|}
\hline الدلالة & قيمة (ف) & المتوسط & درجة الحرية & مجموع المربعات & \\
\hline \multirow{3}{*}{$\cdot, \cdot 1$} & ه & Y $10, r q \wedge$ & 0 & $1 \cdot \vee \neg, \leqslant \wedge \wedge$ & بين المجموعات \\
\hline & & 9,910 & $r \varepsilon$ & $r r \Delta, 11 r$ & المجموعات \\
\hline & & & rq & . ז, & المجموع \\
\hline
\end{tabular}

يتضـح مـن الجدول رقم ( r I ) أن هناك فروق بين بين مجموعات الميول

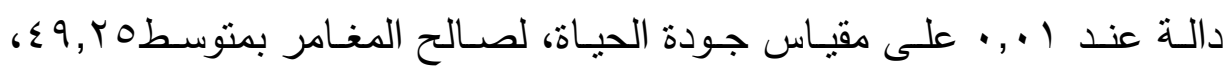

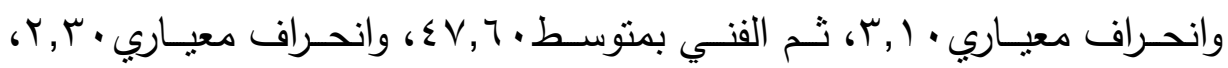

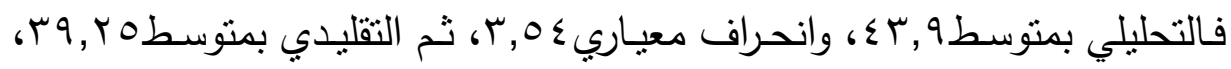

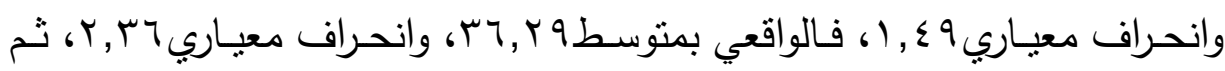

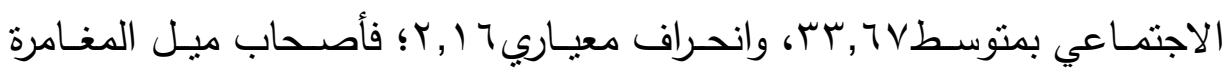
لديهم إدراك لجودة الحياة يفوق أصحاب الميول الأخرى ؛ وهذا يتفق مـع طبيعة الشخصية المغامرة، ويختلف الأطفال الذين يعيشون مع أسرهم في إدراكهم لجودة حياتهم عن أطفال المؤسسات اُيوائية حسب طبيعة الميول. وبالنسبة للفرض الرابع والذي ينص على: "لاتوجد فروق ذات دلالة احصائية بين الذكور والأناث على مقياس جودة الحياة." فبحساب الفروق بين الذكور واُيناث للعينة كلها - أطفال المؤسسات اُيوائية والأطفال الذين يعيشون مع أسرهم كانت النتائج كما هو موضتح في الجدول رقم 
جدول رقم (r ا ) يبين الفروق بين الإناث والذكور على مقياس جودة الحياة

\begin{tabular}{|c|c|c|c|c|c|}
\hline الدلالة & ف & الانحراف المعياري & المتوسط & العدد & النوع الن \\
\hline \multirow[t]{2}{*}{ غير دال } & \multirow[t]{2}{*}{$\cdot, \wedge \varepsilon$} & $r, \xi$ & $r \wedge, \tau$ & «^ & :Sر \\
\hline & & $ץ, \uparrow$ & $r 4,0$ & rr & انثي \\
\hline
\end{tabular}

وتوضح نتائج الجدول السابق عدم وجود فروق بين الذكور والإناث على

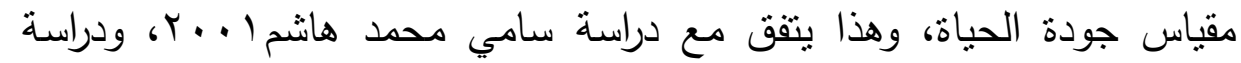

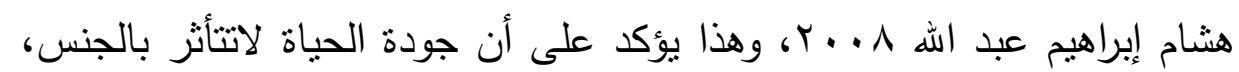

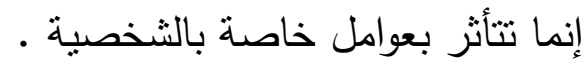
وبالنسبة للفرض الخامس ونصه " يختلف نرتيب الميول المهنية لدى أطفال المؤسسات عنه لاى الأطفال الذين يعيشون مع أسرهم".

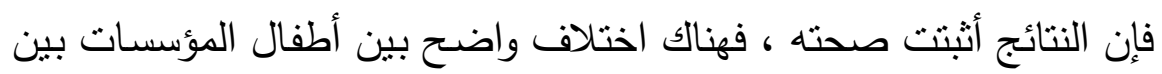
الأطفال الذين يعيشون مع أسرهم من حيث ترتيب الميول وذلك كما في الجدول

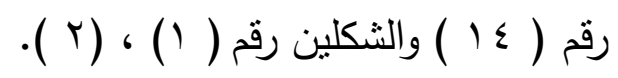

جدول رقم (ع () يبين توزيع الميول لأطفال المؤسسات الإيوائية وأقرانهم

\begin{tabular}{|c|c|c|c|c|c|c|c|}
\hline \multicolumn{8}{|c|}{ الذين يعيشون مع أسرهم } \\
\hline 7 & 0 & $\varepsilon$ & $r$ & $r$ & 1 & العينة & \\
\hline 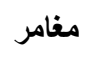 & فني & تحليلي & اجتماعي & تقليدي & واقعي & الميل & أطفال المؤسسات \\
\hline r & $r$ & $r$ & $\wedge$ & 9 & 10 & العدد & \\
\hline 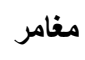 & فني & اجتماعي & واقعي & تقليدي & تحليلي & 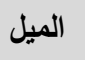 & أطفال مع أسرهم \\
\hline$\varepsilon$ & - & 7 & v & $\wedge$ & 1. & العدد & \\
\hline
\end{tabular}

فالميول الواقعية تقع في المركز الأول لدى أطفال المؤسسات ، وفي المركز

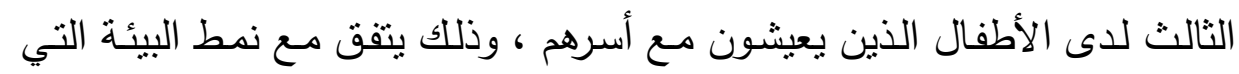

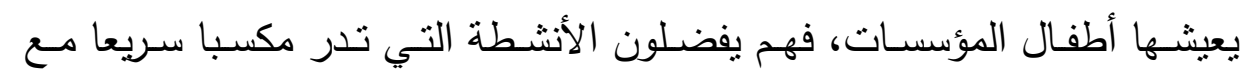


شعورهم بالحرية في ممارستها مثل نقاش أو مزارع، أو سائق، حيث إنهم يعانون في المؤسسة من الحياة الروتينية المنظمة والمقيدة بالقواعد والقوانين .

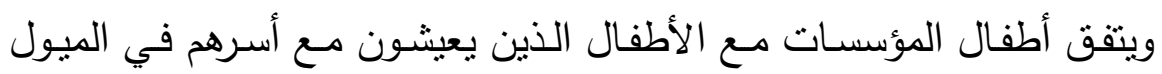

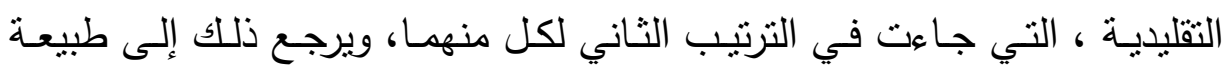

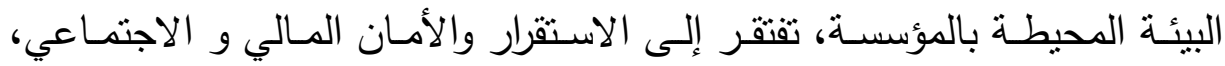
حيث إنها بيئة بين الحضـر والريف، يحدث فيها اختلاط بين البيئة الحضرية

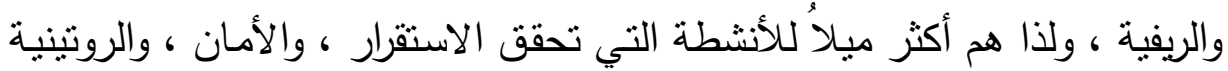

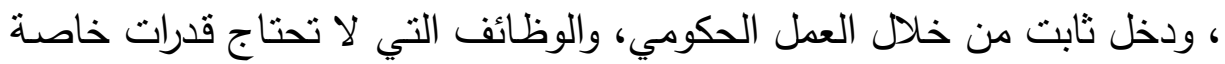

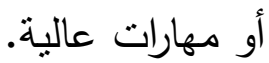

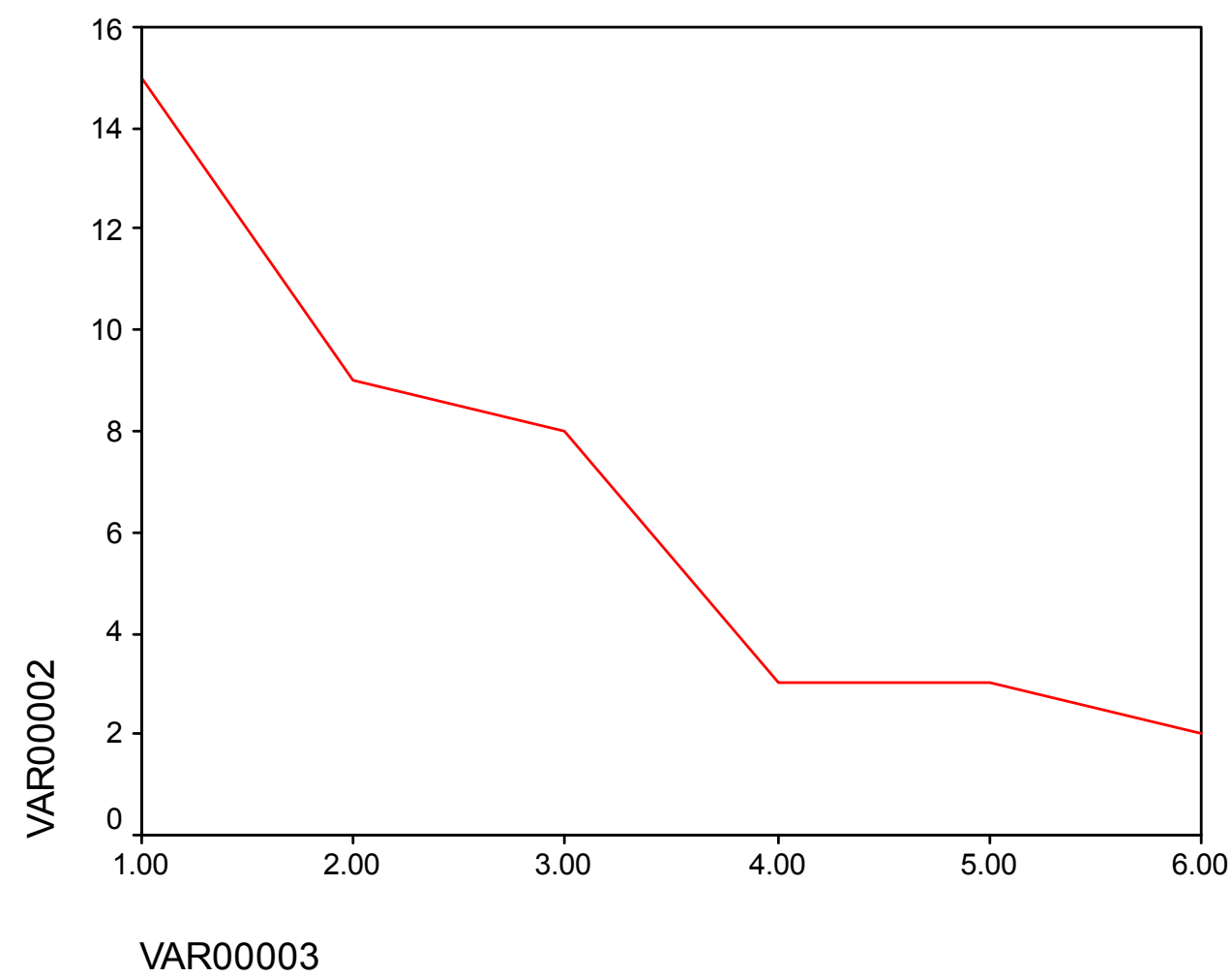

شكل رقم (1 ) يبين توزيع الميول بالنسبة لأطفال المؤسسات 
ويأتي الميل إلى الأنشطة الاجتماعية في المرتبة الثالثة لأطفال المؤسسات

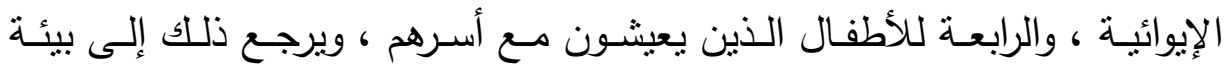

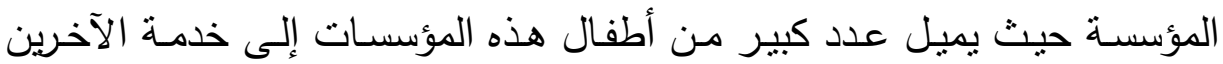

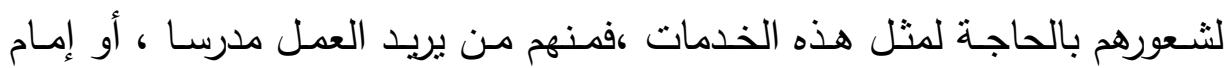

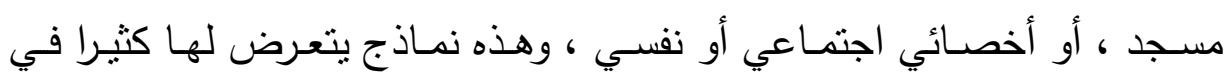

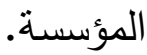

ويأتي الميل التحليلي في المرتبة الرابعة لأطفال المؤسسات الإيوائية ، وفي

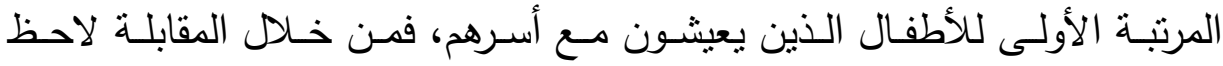

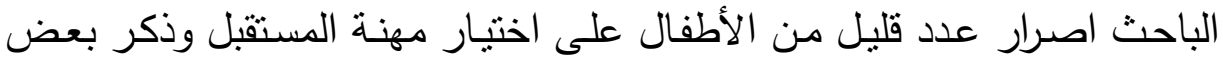

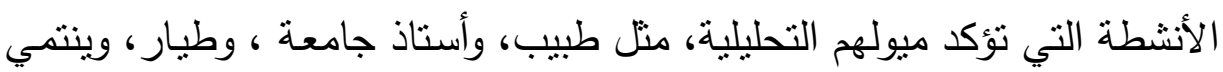

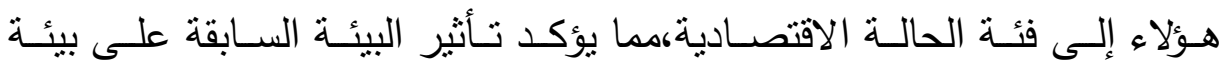

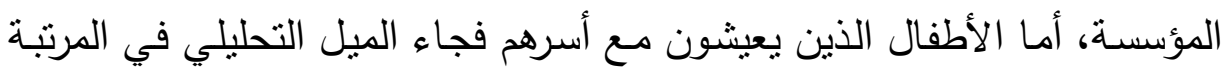

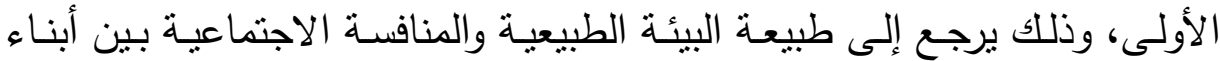

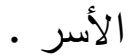




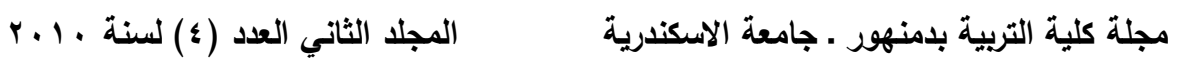

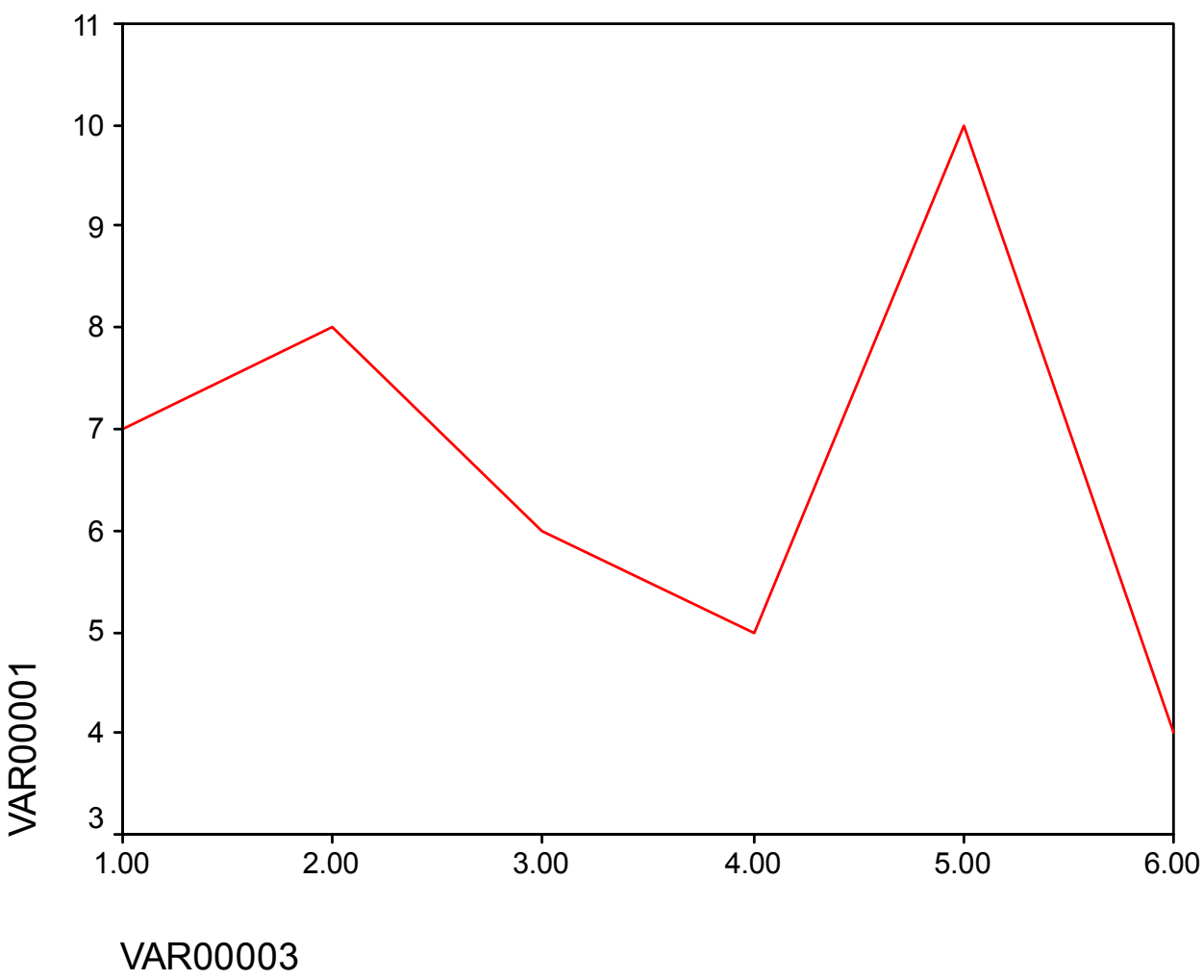

شكل رقم ( r) يبين توزيع الميول المهنية للأطفال العاديين

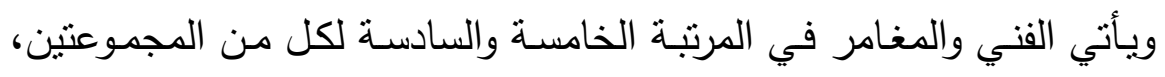

ويتفق ذلك مع طبيعة المؤسسة والبيئة المحيطة بها.

توصيات الدراسة

$$
\text { توصى الدراسة بـ : (الان }
$$

1 - الاهتمام بالتربيـة المهنيـة في المدارس بمراحلهـا المختلفة عامـة، ودور

الرعاية بأنشكالها المختلفة خاصة. 
r - ضرورة الاهتمام بالإعداد الجيد للأخصائيين النفسانيين والاجتماعيين

$$
\text { الذين يعملون مع أطفال المؤسسات الإيوائية. }
$$

r - إجراء مزيد من البحوث والدراسات في مجال جودة الحياة ومصاحباتها

النفسية لاى أطفال المؤسسات، والأطفال المساءة معاملتهم.

ـ - إعداد البرامج الإرشـادية التي تهدف إلى تحسين جوانب الثخصية

المختلفة، لأطفال المؤسسات الإيوائية.

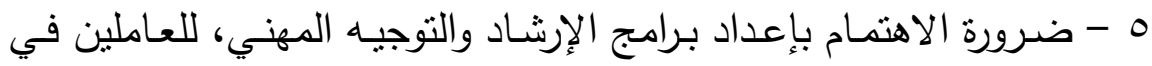

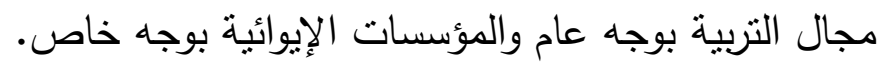

ملخص الدراسة:

هدفت الدراسة إلى التعرف على جودة الحية والميول المهنية لأطفال المؤسسات الإيوائية، مقارنة بأقرانهم الذين يعيشون مع أسرهم، وكذلك إعداد إدهاد

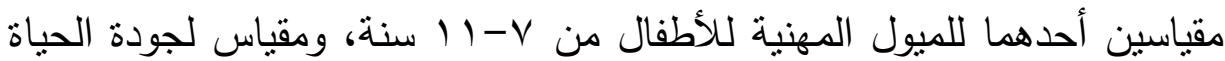


للأطفال ، وهو في صورتين صورة لأطفال المؤسسات، وصورة للأطفال الذين

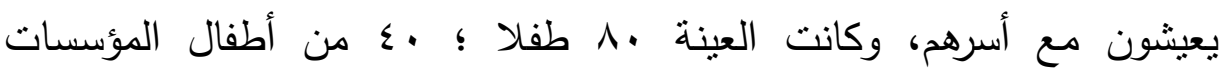
الإيوائية، و •ــ من الأطفال الذين يعيشون مع أسرهم، واستخدت الدراسة المنهج

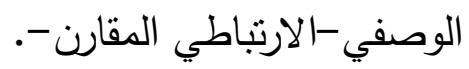

وتوصلت الدراسة إلى أن هناك فروقا بين أطفال المؤسسات الإيوائية والأطفال الذين يعيشون مع أسرهم في إدراكهم لجودة الحياة، لصالح الأطفال

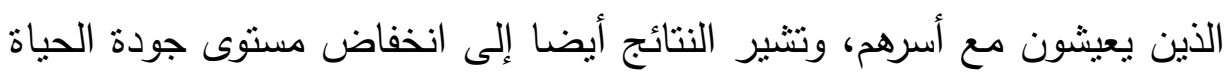

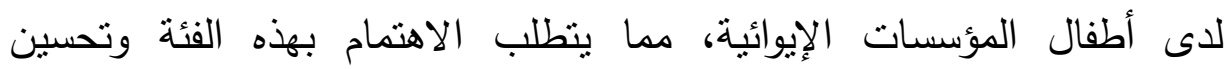

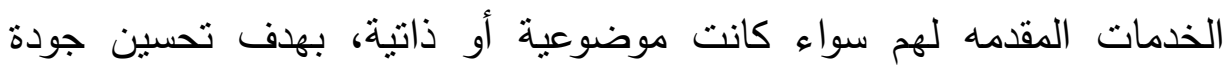

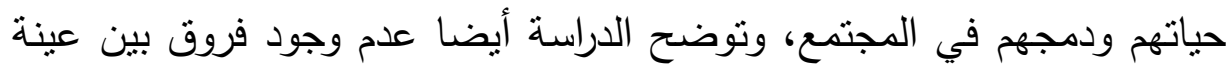

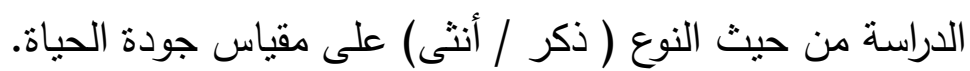

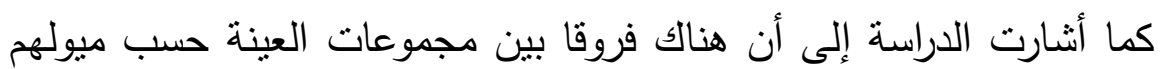
في جودة الحياة، لصالح مجموعة الميل التحليلي بمتوسط بس، يليه المغامر

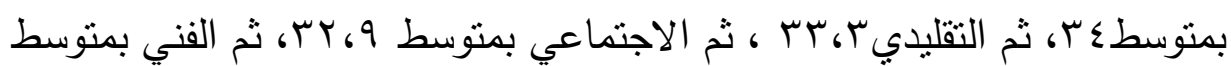

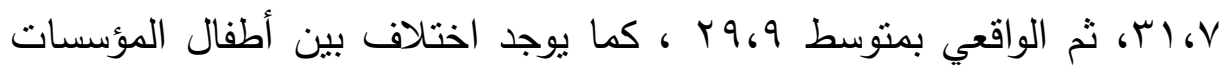
والأطفال الذين يعيشون مع أسرهم، في ترتيب بعض الميول وهي التحليلي

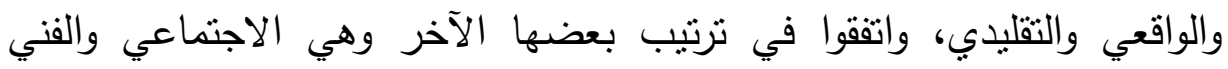

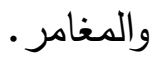

\section{Summary of the study}

The study aimed to identify the quality of life and Vocational Iinterests for the children of residential institutions, compared to their peers who live with their families, as well as the preparation of two scales, one of the Vocational Iinterests for children 
from 7-11 years, and a measure of the quality of life for children, while in the two images of children in institutions, and a picture of children living with their families, and the sample was 80 children; 40 of the children boarding institutions, and 40 of the children who live with their families.

The study found that there are differences between the children of residential and children living with their families, for children who live with their families, and the results suggest also to the low-level, of quality of life of the children of residential institutions, which requires attention to this category and improve the services provided to them, whether objective or subjective, in order to improve the quality of their lives and their integration in society.

The study also no significant differences between the study sample in terms of gender (male / female) on a scale quality of life.

The study also noted that there are differences between the sample groups according to their Iinterests in Quality of Life, the Iinterest for the group of investigative average of 36 , followed by the enterprising with an average $34,33.3$, and the traditional, social, and an average of 32.9, an average of 31.7 and then technical, then the real average of 29.9, and there are differences among institutionalized children and children living with their families, in the order of some of the investigative interests, traditional and realistic and agreed in the order of others like the social, artistic, and adventurous.

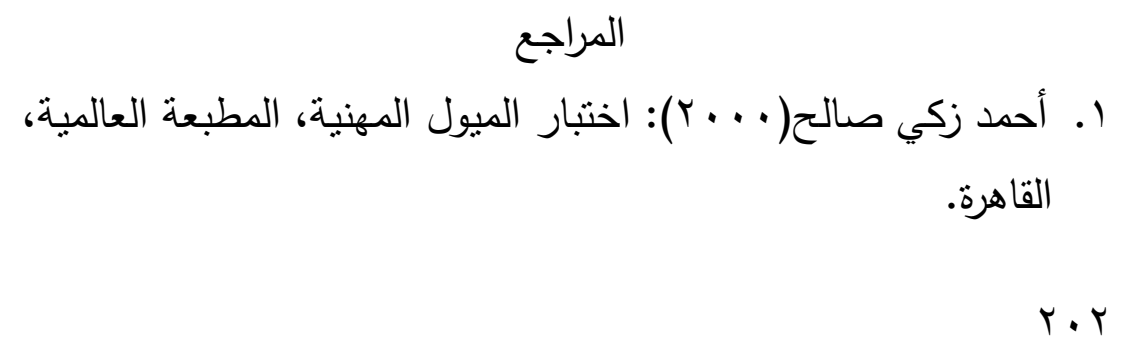


r. أحمــ سـليمان عمـر روبـي( 99 (1): الميول المهنيـة وعلاقتها بالتوجـهـ

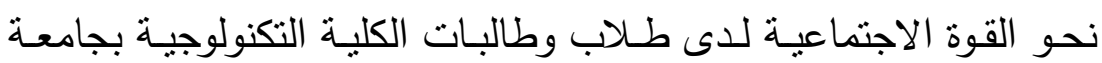

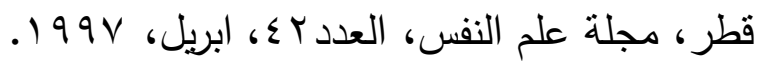

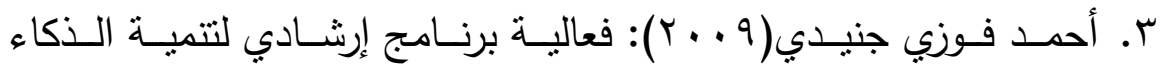
الوجداني في جودة الحياة النفسيثة للتناميذ الموهوين، رسالة دكتوراه غير برني منشورة، كلية التربية بالسويس، جامعة قناة السويس.

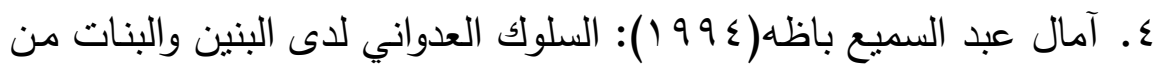
أطفال دور الرعاية الاجتماعية، مجلة كلية تربية طنطا، العدد ·ب، مجلد

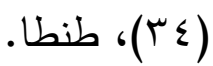
ه. أمل دكاك و أحمد الأصـفر (999 إ: خصـائص الأسـرة واختيـار مهنـة المستقبل بين الأطفال ، مجلة الطفولة والتتمية ، العدد الصفري ، تشرين الصني الثاني ، 110 1

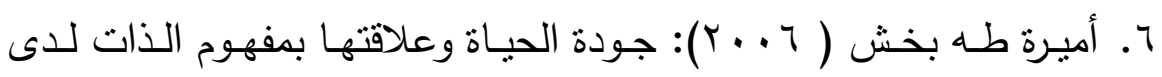
المعاقين بصريا والعاديين بالمملكة العربية السعوية، مجلة كلية التربية،

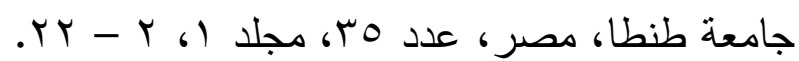

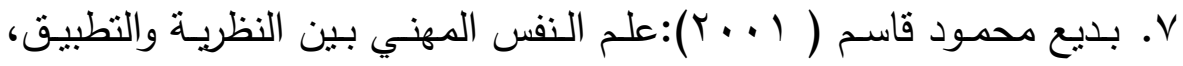
مؤسسة الوراق للنشر والتوزيع، الأردن، عمان.

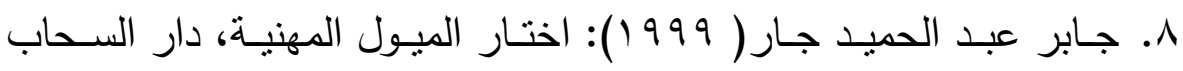
للنشر والتوزيع، القاهرة.

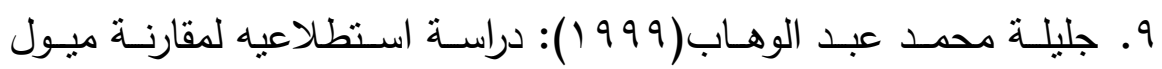
الأطفال في المرحلة العمرية من 9-ـ أمن رواد نوادي الأطفال التابعة

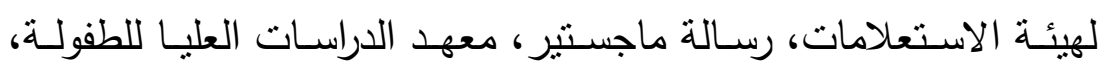
جامعة عين شمس، القاهرة. 
• 1. جمـال شـحاته حبيب( (1990): المخـاطر النفسية والاجتماعيـة التي يتعرض لها أطفال المؤسسات الإيوائية ودور الخدمة الاجتماعية في مواجتها، المؤتمر السنوي الثالث- الطفل المصري بين الخطر والأمان - الهان

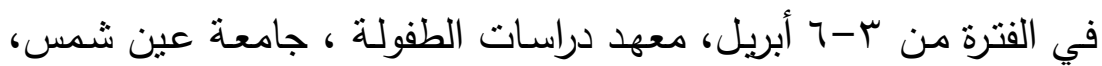

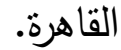

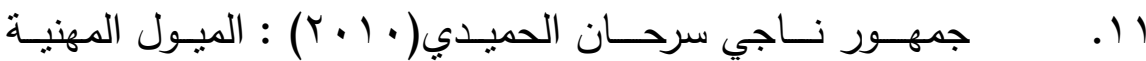
وعلاقتها بسمات الثخصية الموهوبة للطلبة المتفوقين دراسيا بمدينة تعز . دراسة ماجستيرغير منشورة، كلية التربية ، جامعة تعز ، اليمن.

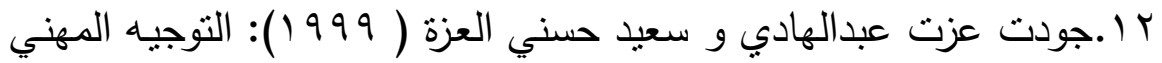
ونظرياته، دار الثقافة، عمان.

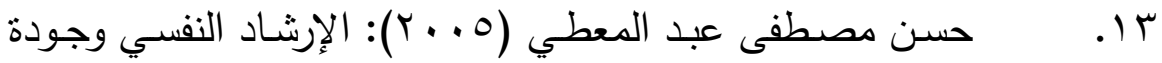
الحيـاة في المجتمـع المعاصـر ـ وقائع المـؤتمر العلمي الثالث: الإنمـاء النفسي والتربوية للإنسان العربي في ضوء جودة الحياة (ص ص س با -

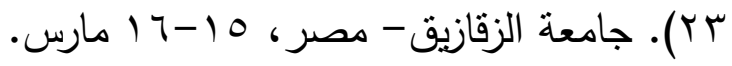

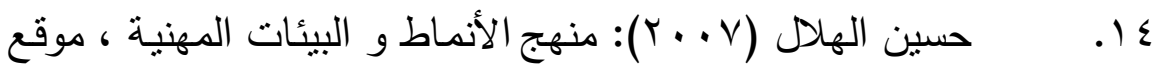

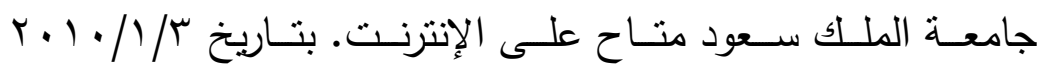
http://www.ksu.edu.sa"

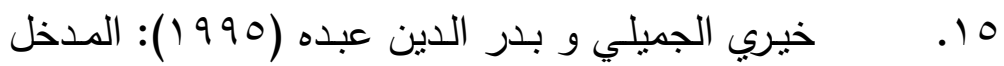
في الممارسة المهنية في مجال الأسرة والطفولة. الإسكندرية : المكتب العلمي للكمبيوتر والنشر والنوزيع.

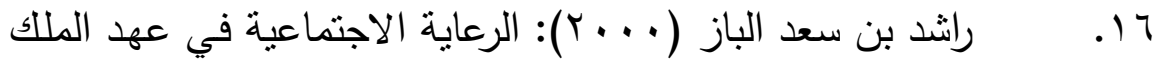
عبد العزيز، مكتبة الملك عبد العزيز العامة، الرياض.

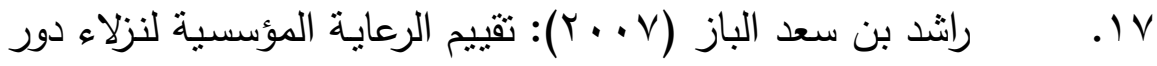
مؤسسـات التربيـة الاجتماعيـة، كليـة العلـوم الاجتماعيـة، جامعـة الإمـام 
محمد بـن سـود الإسـلامية،الرياض. متـاح بتـاريخ r T/9/9 . . . r على

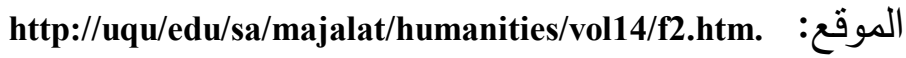
11. ربيع شعلان عبد الحليم (1991): دراسة عاملية للتكوين النفسي للأطفال المحرومين أسريا في ضوء أنماط مختلفة من لحرمان. دكتوراه غير منشورة، كلية التربية جامعة الأزهر، القاهرة. 9 1. دخيل ذاكر العصيمي (997 )): الاختيار المهني وعلاقته ببعض العوامل الاجتماعية والاقتصادية لدى طلبة الصف الثالث ثانوي بمدينة الرياض، رسالة ماجستيرغير منشورة، كلية التربية، جامعة الملك

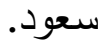

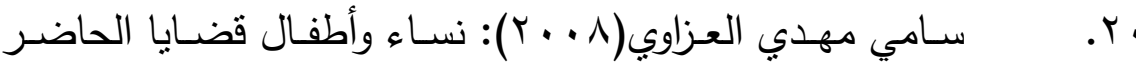
والمستقبل، محددات اختيار الطفل العراقي لمهنة المستقبل،مطبعة القبس،

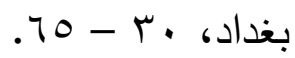

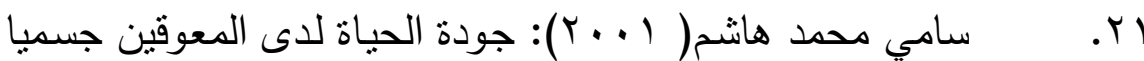

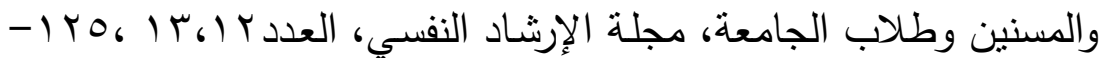
.11 .

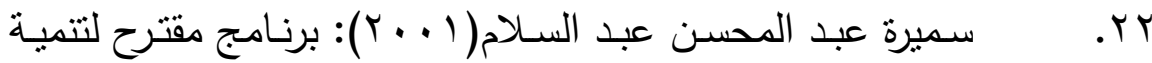

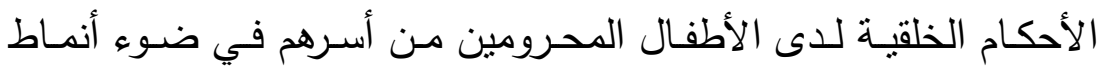
مختلفة من الحرمان، رسالة دكتوراه غير منشورة، كلية التربيـة، جامعـة الأزهر ، القاهرة.

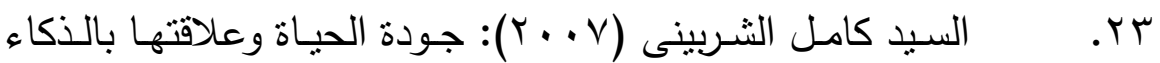
الانفعالى وسمة مـا وراء المزاج والعوامل الخمسـة الكبرى فـى الثخصية

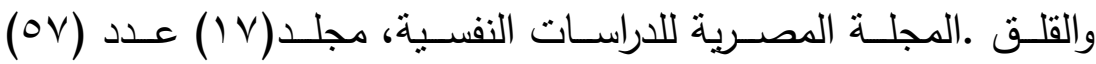

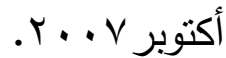




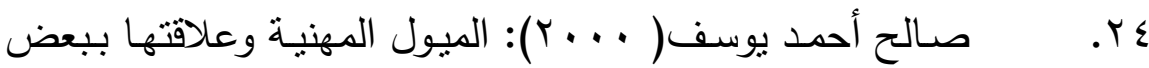
انماط الشخصية كمدخل للتوجيه التربوي لطـلاب المرحلة الثانوبـة بدولة أمارات العربية المتحدة، رسالة دكتوراة ، معهد الدراسات التربوبة ، جامعة القاهرة.

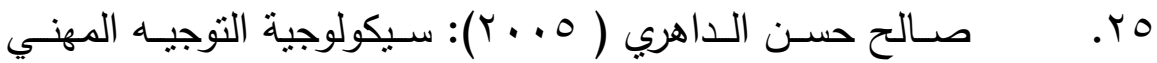
ونظرياته، دار وائل للنشر والتوزبع، عمان.

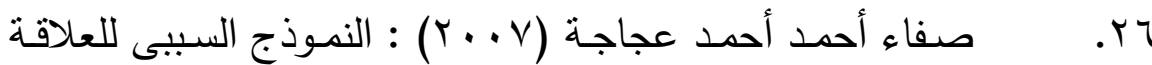
بين الذكاء الوجدانى وأساليب مواجهة الضغوط وجودة الحياة لدى طلاب الجامعة •رسالة ماجستير، كلية التربية "صحة نفسية" ، جامعة الزقازيق .

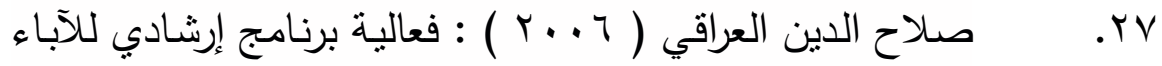
لتحسين جودة الحياة لدى أبنائهم ذوي الاحتياجات الخاصـة ، مجلة كلية

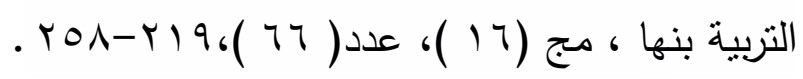

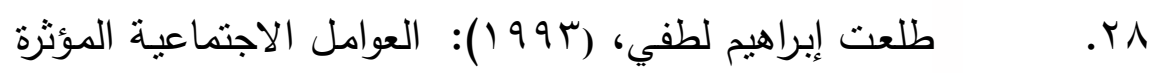
على اختيار نوع التعليم والمهنة، مجلة حوليات كلية الآداب، جامعة عين

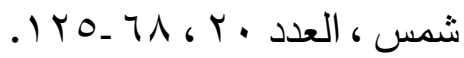

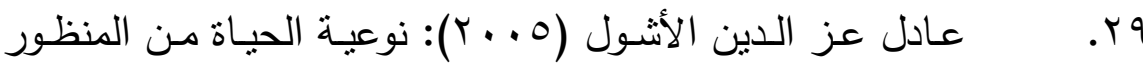
الاجتمـاعي والنفسـي والطبـي. وقـائع المـؤتمر العلمـي الثالـث: الإنمـاء النفسي والتربوبة للإنسان العربي في ضوء جودة الحباة ، - 1 (، جامعة الزقازيق - مصر ، 0 - 17 1 مارس.

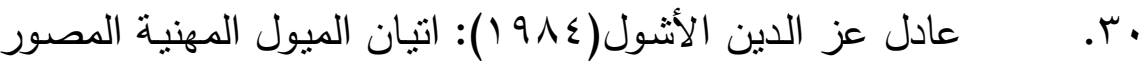
للمتخلفين عقليا.

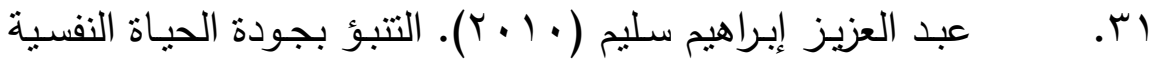
فـي ضـوء توجهـات أهـداف الإنجــاز وبعـض اســراتيجيات مواجهـة 
الضـغوط، مجلـة الدراسـات التربويـة والإنسـانية،المجلد الثناني، العدد (1): 191 - 19 10، تصدرها كلية التربية بدمنهور ، جامعة الإسكندرية.

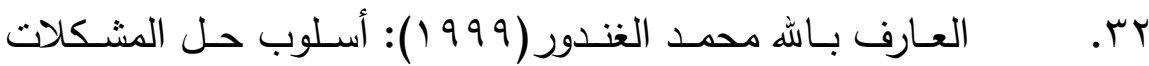
وعلاقتـهـه بنوعيـة الحياة"دراســة نظريـة"المؤتمر الــولى السـادس لمركـز

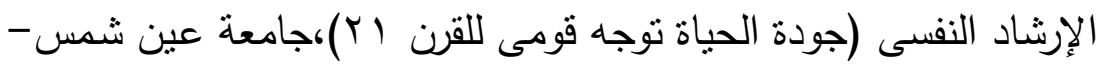

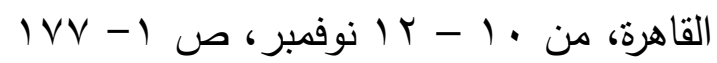

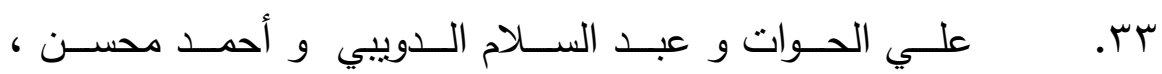
(919 (1): رعايـة الطفل المحروم : الأسس الاجتماعيـة والنفسية للرعايـة

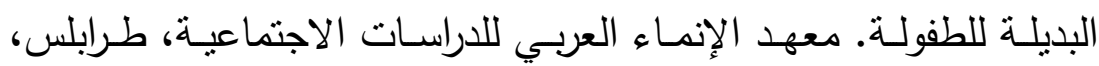
ليبيا.

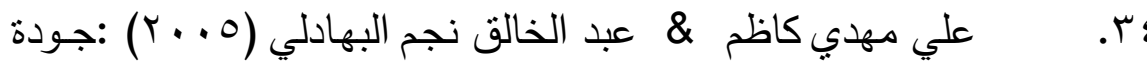

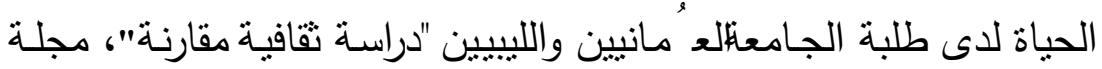

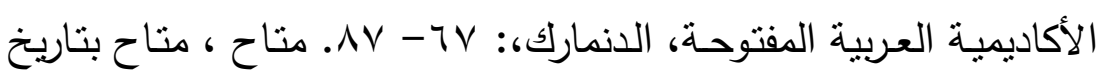
http://www.avademy.org/docs/third- issue-1.doc

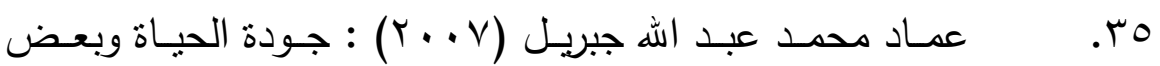

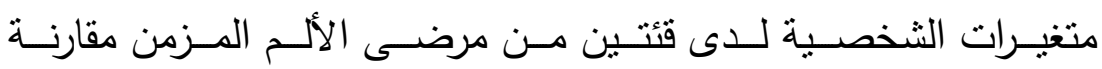
بالأصحاء، رسالة ماجستير ، كلية أداب علم نفس ، جامعة المنوفية.

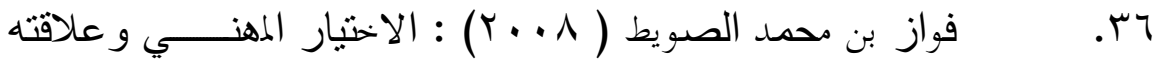
بالتوافق النفسي لـى ضباط قاعدة الملك فهد الجويـة ،ماجستير ، كلية التربية ، جامعة أم القرى، وجى (مكة المكرمة.

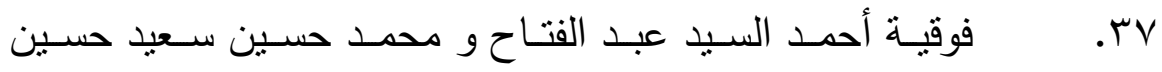

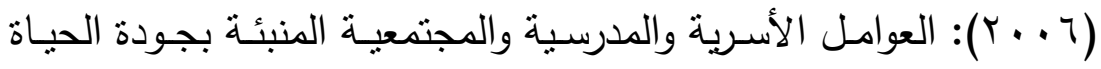

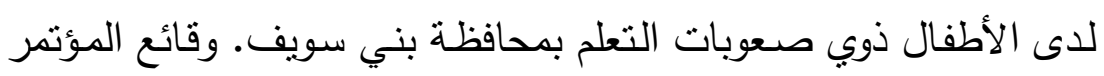


العلمـي الرابـع: دور الأسـرة ومؤسسـات المجتــع المـدني في لاكتشـاف

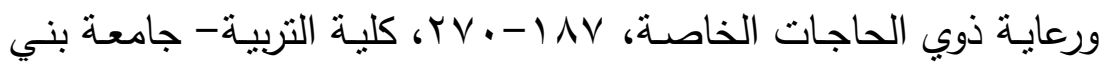

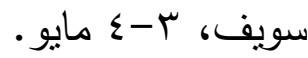

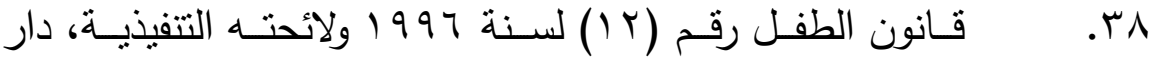

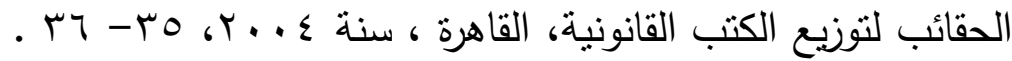

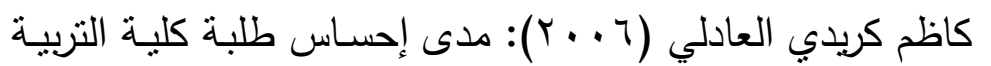
بالرستاق بجودة الحياة وعلاقة ذلك ببعض المتغيرات. وقائع ندوة علم

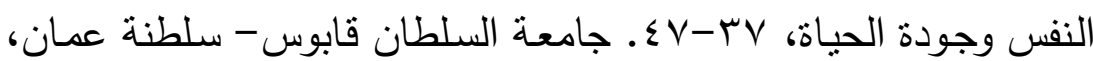
• I 19 19

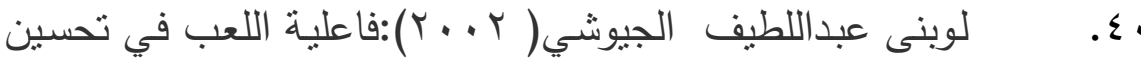
بعض أنماط السلوك الإجتماعي لدى أطفال المؤسسات الإوائية، دراسـة ماجستير غير منشورة، معهد الدراسات التربوية، جامعة القاهرة.

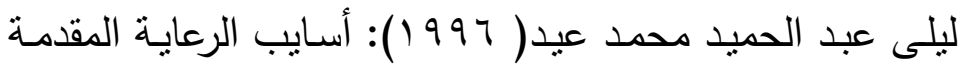

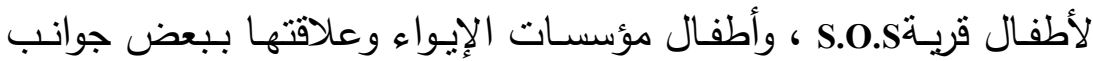

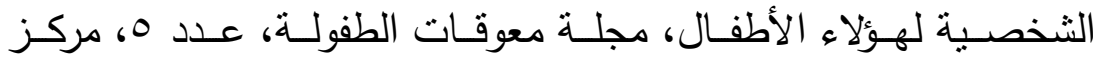
معوقات الطفولة ، جامعة الأزهر ، القاهرة،

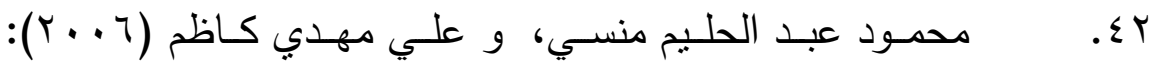
مقياس جودة الحياة لطلبة الجامعة. وقائع ندوة علم النفس وجودة الحياة،

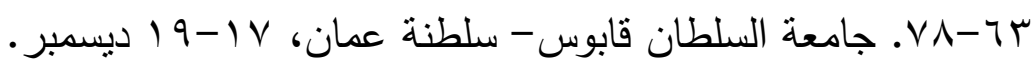

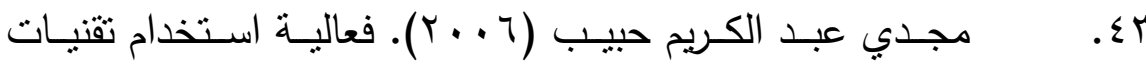

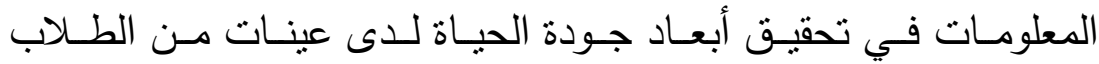

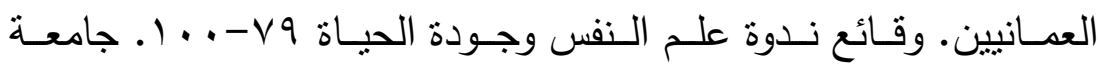

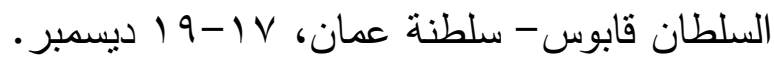




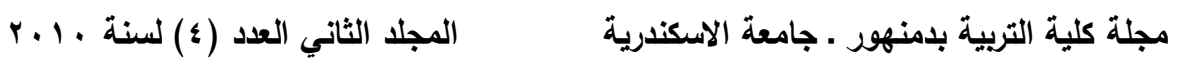

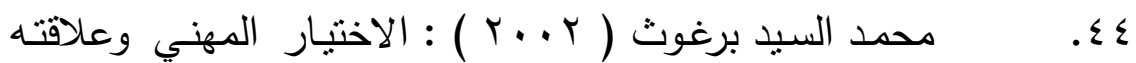

بالعملية التوافقية الإيجابية لطلبة الكلية الحربية، رسالة ماجستير غير منشورة، جامعة عين شمس.

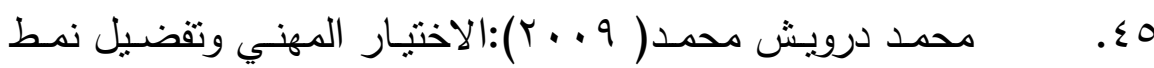
الشخصية لدى طلاب الجامعة ،المؤتمر العلمي التربوي النفسي، جامعة

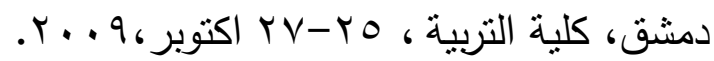

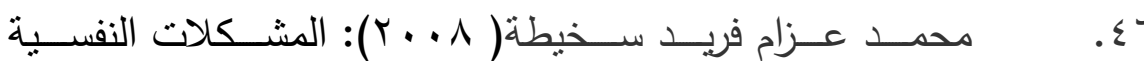
والإضـرابات السلوكية السـائدة من المؤسسات الإيوائية وسبل الوقائية من مخـاطر الإسـاءة والانحـراف عنـد الأيتـام، دراسـة حالـة، المـؤتمر الثاني لرعايـة الطفل اليتيم، المؤسسـة الخيربـة الملكيـة، البحرين ع ا -ه أبربـل r...

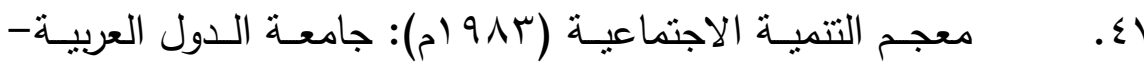
إدارة العمل الاجتماعي، القاهرة.

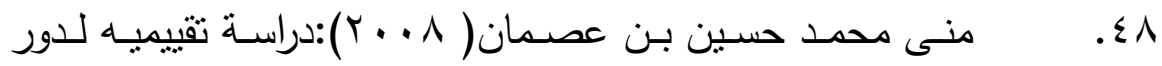
المؤسسـات الاجتماعيـة الإيوائيـة في رعايـة الطفل المحروم مـن الأسـرة الطبيعية ، دراسة ماجستير ،جامعة الفاتح، كلية الاداب، ليبيا، طرابلس.

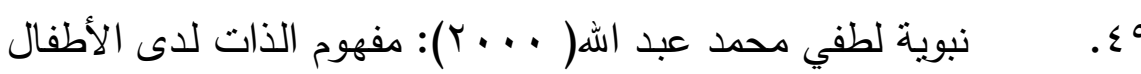
المحرومين من الأم_- دراسـة مقارنـة_رسالة ماجستير غير منشورة معهد الدراسات العليا للطفولة، جامعة عين شمس، القاهرة. ه. - الوجـه الآخـر للإِــقلالية ، جمعيـة سـتيفن للصـحة النفسية، جامعـة

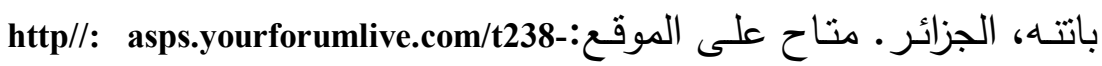
topic 
1. جماعـات الأطفـال مجهولي النسـب لتعديل سـوكهم اللاتـوافقي ، رسـالة دكتوراة، كلية الخمة الاجتماعية ، حلوان.

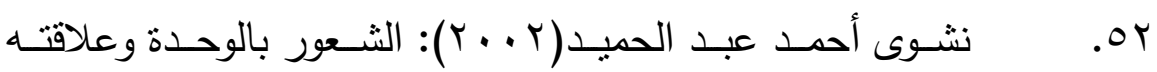
بـالتولفق النفسي والاجتمـاعي للدى عينة من الأطفال المحرومين مغير المحرومين من الرعايـة السرية، رسـالة ماجستير ، معهد الدراسـات العليا للطفولة جامعة عين شمس،.

به. نصـر الـدين أمحمـد عمر أبـو شـندي( ( . ب): العلاقـة بـين بعض الميول المهنية ومستوي التحصيل الدراسي لدي عينة من طلاب التعليم المتوسط بمدينـة طرابلس،ماجستير ، جامعـة الفـاتح ـ كليـة الآداب ـ قسـم التربية وعلم النفس، ليبيا.

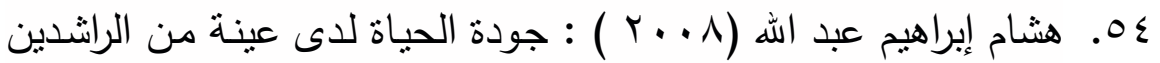
في ضوء بعض المتغيرات الديموجرافية ، مجلة دراسات تربوبية واجتماعية

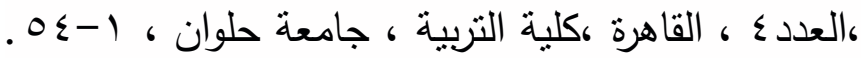

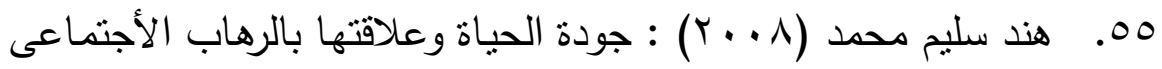
لـدى طـلاب المرحلـة الثانوبـة، رسـالة ماجسـتير ، كليـة تربيـة"علم نفس تربوى"،جامعة حلوان.

7ه. وفاء عبد الجواد وعزة خليل عبد الفتاح (999 (): فعالية برنامج لخفض السلوك العدواني باستخدام اللعب لدى الأطفال المعاقين سمعيا، مجلة علم النفس، العدد •م،الهيئة المصرية العامة للكتاب، القاهرة.

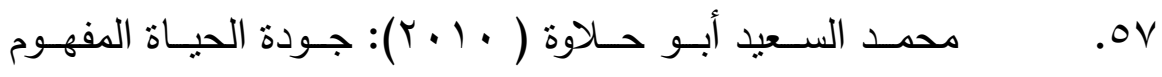
والأبعاد، المؤتمر العلمي السنوي لكلية التربية، جامعة كفر الثيخ.

58. Alika, H. I.,\& Egbochuku, E. O.,(2009) : vocational interest, counselling, socioeconomic Status and age as correlates, Edo Journal of Counselling Vol. 2, No. 1 May 2009. 
59. Andalman, R. B., Attkisson, C. C., Zima, B. T., \& Rosenblatt, A. B. (1999): Quality of life of children: Use of psychological testing for treatment planning and outcomes assessment (pp. 1383-1413). Mahwah, New Jersey: Lawrence Erlbaum Associates.

60. Baba Khetannath Mahila(2009): Study Of Scholastic Achievement And Vocational Interest Of The Adolescent Of Educated And Uneducated Mothers_(International Research Journal)_ISSN-0974-2832 Vol. II, Issue-9-10 (Oct.-Nov.-2009).

61. Barth, Richard (1999): Outcome research in the USA. The forth international conference: From the looking after children initiative, 21-24 Sept. Oxford: University of Oxford.

62. Berridge, D and Brodie, I. (1998): Children's home revisited. London: Jessica Kingsley, Publishers.

63. Berridge, D. (1994): Foster and resi-dential care reassessed: A research perspective. Children and Society. pages 132 150, June 1994

64. Bishop, M., \& Feist-Price, S. (2001): Quality of life in rehabilitation counseling: Making the philosophical practical. Rehabilitation Education, 15 (3), 201-212.

65. Chamorro-Premuzic, T., Bennet, E \& Furnham, A. (2006): the happy Personality: Mediational role of trait emotional intelligence. , Personality and Individual Differences 42 (2007) 1633-1639

66. Clark ,M., Rous,S., \& Rudd, M.,(2005): Predictive and Treatment Validity of Life Satisfaction and the Quality of Life Inventory.Assessment,Vol.21(1) 66-78.

67. Colton, M.; Aldgate, J. and Heath, A. (1991): Behavioral problems among children in and out of care. Social Work and Social Science Review, 2(3): 177-191.

68. Craig A. Jackson (2010). Work-RelatedQuality of Life, Health Research Consultation Center, Oxford University Press.

69. crystal l, park (2003): the psychology of religion and positive psychology. psychology of religion. newsletter, volume $28, \mathrm{n} \mathrm{o} .4$, pp. 120. american psychological association division 36.

70. Cummins, R. A. (1997): Assessing quality of life. In R. I. Brown (Ed.),Quality of life for people with disabilities: Model research, and practice, (pp.116 -150) Cheltenham, U.KL Stanley Thornens.

71. Diener, E., Suh, E.M., Lucas, R.E., \& Smith, H.L. (1999): Subjective well-being: Three decades of progress. Psychological Bulletin, 125, 276302.

72. Diener,E., \& Diener, M. (1995): Cross cultural correlates of life satisfaction and self esteem. Journal of Personality and Social Psychology. 68,653-663.

73. Dodson, W. E. (1994): Quality of life measurement in children with epilepsy. In: M. R. Trimble \& W. E. Dodson (Eds.), Epilepsy and Quality of Life (pp. 217-226). New York: Raven Press Ltd.

74. Eng, W, Cole, M.E, Heimberg, R.G., \& safren, S. (2005): Domain life satisfaction in social anxiety disorder: relation to symptoms and response to cognitive behavioral therapy. Journal of anxiety disorder 19(2), 143156. 
75. Gilman, R., Easterbrooks, S., \& Frey, M. (2004): A preliminary study of multidimensional life satisfaction among deaf/hard of hearing youth across environmental settings. Social Indicators' Research, 66, 143-166.

76. Goode, D. (1994): Quality of life for persons with disabilities: International Perspectives and issues; in: Mitchel, D. (1997): Book Review; Journal of Intellectual \& Developmental Disability; Vol. 22(1), pp.63-75.

77. Harman, W.W. (1996): Reassessing the economic assumption, Futurist; Vol.30 (4) pp.13-18.

78. Heath, A.; Colton, M. Aldgate, J. (1993): Failure to escape: A long-itudinal study of foster children educational attainment British Journal of Social Work. Volume 42, Issue 3

79. Jonker,C., Gerritsen.D.L, Bosboom P.R.\&, J.T. Van der Steen J.T. (2004): A Model for Quality of Life Measures in Patients with Dementia: Lawton's Next Step. Dementia and Geriatric Cognitive Disorders; 18:159164.

80. Karen, O., Lambour, G. \& Greenspan, S. (1990): Persons in transition. In: R. L. Schalock \& M. Begab (Eds.), Quality of life perspectives and issues (pp. 85-92). Washington: American Association on Mental Retardation.

81. Borman ,M., and Kurdek A., (1984): Children's Game Complexity as a Predictor of Later Perceived Self Competence and Occupational Interest, Distributed by ERIC Clearinghouse, 29.

82. Logue, T., Lounsbury, W., Gupta, A., \& Leong, ,T.,(2007): Vocational Interest Themes and Personality Traits in Relation to College Major Satisfaction of Business Students, Dissertation The University Of Tennessee, Journal of Career Development, Volume 33, Number, 3March, 2007,269-295.

83. Palmer,B.,Gignac,G.,Bates ,T.,\& stough, CV.(2003): Examining the structure of the trait meta-mood scale. Australian journal of psychology, 55(3), 154-158.

84. Reine,G.,Lancon,C.,Tucci,S., Sapin,C. \& Auquier, P.(2003): Depression and Subjectiv quality of life in chronic phase schizophrenic patients. Act Psychiatrica

85. RosslerR.,( 1990): A quality of life prspectiv on rehabilitation counseling.Rehabilitation Counsling Bulletin, Vol.34, No.2, PP.1-7, Scandinavica. vol. 108, PP. 297-303.

86. Shek,D.,lee,t.9(2007): family life quality and emotional quality of life in Chinese adolescents with and without economic disadvantage, social imdicators research, vol.80(2),393-410.

87. Stafford\& $\mathrm{k}$. Stafford(1995):aggressive playground behaviour in children with emotional and/or behavioural difficulties, educational studies , vol.21,no.2.

88. Taylor, S.J. \& Bogdan R. (1996): Quality of life and the individual's perspective. In Quality of Life: Conceptualisation and measurement. Ed. R. Schalock. American Association on Mental Retardation. Washington D.C. 
المجلد الثاني العدد (؛ ) لسنة ـ ـ مجلة كلية التربية بدمنهور · جامعة الاسكندرية

89. Vitterso, J. (2001): Personality traits and subjective well-being emotional stability, not extraversion, is probably the important predictor, Personality and Individual Difference, 31(6), 903-914.

90. Vreeke, G.J., Janssen, S., Resnick, S., \& Stolk J. (1997): The quality of life of people with mental retardation: in search of an adequate approach. International Journal of rehabilitation Research. 20 pp280301.

91. Whiston, S (1996) : The Relationship Among Family Interaction Patterns And Career In Decision And Career Decision making Self - Efficacy . Journal Of Career Development . Vol 23 . No (2) Pp 137 - 149.

36. World Health Organization Quality of Life Group. (1995): TheWorld Health Organization Quality of Life Assessment, (WHOQOL): Position paper from the World Health Organization. Social Science and Medicine, 41, 1403-1409. 
جودة الحياة لاى أطفال المؤسسات الإيوائية وميونهم المهنية (دراسة مقارنة مع الأطفال الذين يعيشون مع أسرهم) د.حمدى محمد شحاته عرقوب

Y) 